\title{
Two new frog species from the Litoria rubella species group from eastern Australia
}

\author{
J. J. L. ROWLEY ${ }^{1,2 *}$, M. J. MAHONY ${ }^{3}$, H. B. HINES ${ }^{4,5}$, S. MYERS ${ }^{6,7}$, L.C. PRICE ${ }^{8}$, G.M. SHEA ${ }^{1,9}$ \\ \& S. C. DONNELLAN ${ }^{6}$ \\ ${ }^{1}$ Australian Museum Research Institute, Australian Museum, 1 William St, Sydney 2010, Australia. \\ ${ }^{2}$ Centre for Ecosystem Science, School of Biological, Earth and Environmental Sciences, University of New South Wales, Sydney, NSW \\ 2052, Australia. \\ ${ }^{3}$ School of Environmental and Life Sciences, The University of Newcastle, University Drive, Callaghan, 2308, Australia. \\ "”michael.mahony@newcastle.edu.au; (1) https://orcid.org/0000-0002-1042-0848 \\ ${ }^{4}$ Department of Environment and Science, PO Box 64, Bellbowrie, Qld, 4070, Australia. \\ ”-Harry.Hines@des.qld.gov.au; @ https://orcid.org/0000-0001-5547-5693 \\ ${ }^{5}$ Honorary Research Fellow, Biodiversity, Queensland Museum, PO Box 3300, South Brisbane, QLD 4101 \\ ${ }^{6}$ South Australian Museum, North Terrace, Adelaide, Adelaide, 5000, Australia. \\ ఏ"Steve.donnellan@samuseum.sa.gov.au; @ https://orcid.org/0000-0002-5448-3226 \\ ${ }^{7}$ ALS Water Resources Group, 22 Dalmore Drive, Scoresby, Victoria, 3179, Australia. \\ इ"Steven.Myers@alsglobal.com; — https://orcid.org/0000-0001-8885-8770 \\ ${ }^{8}$ School of Biological Sciences, University of Adelaide, 5005, Australia. \\ ${ }^{9}$ Sydney School of Veterinary Science B01, University of Sydney, NSW 2006, Australia. \\ झ" glenn.shea@sydney.edu.au; ○ https://orcid.org/0000-0002-0052-4205 \\ *Corresponding author. ”Jodi.Rowley@austmus.gov.au; @ittps://orcid.org/0000-0002-2011-9143
}

\begin{abstract}
The bleating tree frog (Litoria dentata) is one of the more prominent pelodryadid frogs of eastern Australia by virtue of its extremely loud, piercing, male advertisement call. A member of the Litoria rubella species group, L. dentata has a broad latitudinal distribution and is widespread from coastal and subcoastal lowlands through to montane areas. A recent mitochondrial DNA analysis showed a deep phylogeographic break between populations of L. dentata on the mid-north coast of New South Wales. Here we extended the mitochondrial survey with more geographically comprehensive sampling and tested the systematic implications of our findings with nuclear genome wide single-nucleotide polymorphism, morphological and male advertisement call datasets. While similar in appearance and in male advertisement call, our integrative analysis demonstrates the presence of three species which replace each other in a north-south series. We redescribe Litoria dentata, which is restricted to coastal north-eastern New South Wales, and formally describe Litoria balatus sp. nov., from south-eastern Queensland, and Litoria quiritatus sp. nov., from the mid-coast of New South Wales to north-eastern Victoria.
\end{abstract}

Key words: Frog diversity, genetic diversity, species complex

\section{Introduction}

The reconstruction of the biogeographic history of eastern Australian forest fauna has long occupied the interest of evolutionary biologists (Joseph et al. 1993; Joseph \& Moritz 1994; Byrne et al. 2011; Bryant \& Krosch 2016). Numerous reptile, e.g., Eulamprus (O’Connor \& Moritz 2003), Lampropholis (Chapple et al. 2011a,b), Saproscincus (Moussalli et al. 2005), Saltuarius (Couper et al. 2008) and Phyllurus (Hoskin et al. 2003), and frog groups, e.g., Crinia (Symula et al. 2008), Philoria (Knowles et al. 2004), Limnodynastes (Schauble et al. 2000; Schauble \& Moritz 2001) and Litoria (McGuigan et al. 1998; Donnellan et al. 1999; James \& Moritz 2000; Mahony et al. 2001) have provided comparative data for the identification of several barriers in mid-eastern forests influencing the distribution of both species and intra-specific genetic lineages (Bryant \& Krosch 2016). Given the high incidence of species boundaries and phylogeographic breaks coincident with these biogeographic boundaries, and the 
importance of understanding species numbers and distributions in conservation management and land-use planning, a phylogeographic analysis of many reptile and frog species with distribution ranges spanning these biogeographic areas is warranted.

Litoria dentata (Keferstein 1868) is a member of the Litoria rubella (Gray 1842) species group (sensu Tyler \& Davies 1978, 1983) which comprises three species from Indonesia and New Guinea [L. capitula (Tyler, 1968), $L$. congenita (Peters \& Doria 1878) and L. pygmaea (Meyer 1875)], and three from Australia [L. dentata (Keferstein, 1868), L. electrica Ingram \& Corben, 1990 and L. rubella (Gray 1842) which occurs also in New Guinea]. Litoria dentata is a well-known species from mid-eastern Australia by virtue of its very loud high-pitched call and its tolerance of disturbed habitats. These medium-sized (adult body length 30-50 $\mathrm{mm}$ ) frogs call from the ground or emergent vegetation associated with water courses and ponds in both natural and disturbed habitats. The species is found from south-eastern Victoria north to south-eastern Queensland (Gillespie \& Kum 2011), a distribution that encompasses some well-known biogeographic boundaries, i.e. Brisbane Valley and Hunter Valley Barriers (Ford 1987; Bryant \& Krosch 2016). It has also been introduced onto Lord Howe Island (Plenderleith et al. 2015). A recent study revealed a deep phylogeographic break in the mitochondrial DNA (mtDNA) of L. dentata, between populations on the mid-north coast of New South Wales (NSW) (Plenderleith et al. 2015).

Here we extended the survey of Plenderleith et al. (2015) with a more geographically comprehensive mitochondrial phylogeographic analysis and we test the systematic implications of mtDNA structure with genome wide single-nucleotide polymorphisms (SNP), morphological and male advertisement call datasets. Thus, we provide a thorough assessment of geographic variation and examine evidence for contact between putative species before making taxonomic changes as recommended by Chambers \& Hillis (2020). Our integrative analysis demonstrates the presence of three species which replace each other in a north-south series. We herein redescribe Litoria dentata and describe two new species.

\section{Materials and Methods}

Mitochondrial DNA. We obtained nucleotide sequences of the mitochondrial ND4 gene from 74 Litoria dentata and from four other taxa in the Litoria rubella species group: L. congenita, L. electrica, L. pygmaea and L. rubella (Table 1, Fig. 1). The phylogenetic analysis of Rosauer et al. (2009) showed that the L. peronii Tschudi, 1838 species group (sensu Tyler \& Davies 1978) is a close relative of the L. rubella species group, so we used sequences from a selection of taxa from the L. peronii species group as outgroups for phylogenetic analyses (Table 1). DNA was extracted from liver, muscle, or skin swabs with a Gentra Purgene kit (Qiagen). The ND4 gene was PCR amplified and directly sequenced with the primers: 5'-TGA CTA CCA AAA GCT CAT GTA GAA GC-3' and 5'-GGT YAC GAG YAA TTA GCA GTT CT-3' using established protocols (Anstis et al. 2016). We present the full alignment in the Supplementary File, and GenBank accession numbers for the longer sequences are listed in Table 1, as GenBank has a minimum threshold length for accepting data of $>200 \mathrm{bp}$.

TABLE 1. Specimens of Litoria examined for molecular genetic analyses.

Locality \# - number used to identify the locality in tables and figures. SNP cluster: $\mathrm{b}-L$. balatus sp. nov., $\mathrm{d}-L$. dentata, and q-L. quiritatus sp. nov. ND4-GenBank accession number. Supplementary entries in ND4 column refers to sequences $<200 \mathrm{bp}$ in the alignment presented in the Supplementary File. ABTC Number-tissue accession number, Australian Biological Tissue Collection South Australian Museum. Voucher institutions: AMS-Australian Museum, Sydney; ANWC - Australian National Wildlife Collection, CSIRO Canberra; SAMA — South Australian Museum, Adelaide; QM-Queensland Museum, Brisbane. NP—National Park. NSW—New South Wales, Qld—Queensland.

\begin{tabular}{|c|c|c|c|c|c|c|c|c|c|}
\hline Taxon & $\begin{array}{l}\text { SNP } \\
\text { cluster }\end{array}$ & ND4 & $\begin{array}{l}\text { ABTC } \\
\text { Number }\end{array}$ & $\begin{array}{l}\text { Locality \#/ } \\
\text { Locality }\end{array}$ & State & Latitude & Longitude & $\begin{array}{l}\text { Voucher } \\
\text { Institution }\end{array}$ & $\begin{array}{l}\text { Voucher } \\
\text { RegNum }\end{array}$ \\
\hline quiritatus & - & MW885785 & 12646 & $\begin{array}{l}\text { 1-10 km S } \\
\text { Mittagong, on } \\
\text { Kangaloon Rd }\end{array}$ & NSW & -34.530 & 150.480 & SAMA & R40858 \\
\hline quiritatus & - & MW885786 & 145056 & 2-Coalcliff & NSW & -34.247 & 150.975 & AMS & R185759 \\
\hline
\end{tabular}

...... Continued on the next page 
TABLE 1. (continued)

\begin{tabular}{|c|c|c|c|c|c|c|c|c|c|}
\hline Taxon & $\begin{array}{l}\text { SNP } \\
\text { cluster }\end{array}$ & $N D 4$ & $\begin{array}{l}\text { ABTC } \\
\text { Number }\end{array}$ & $\begin{array}{l}\text { Locality \#/ } \\
\text { Locality }\end{array}$ & State & Latitude & Longitude & $\begin{array}{l}\text { Voucher } \\
\text { Institution }\end{array}$ & $\begin{array}{l}\text { Voucher } \\
\text { RegNum }\end{array}$ \\
\hline quiritatus & $q$ & KM199723 & 86208 & $\begin{array}{l}\text { 3-Homebush } \\
\text { Bay }\end{array}$ & NSW & -33.842 & 151.058 & AMS & R147041 \\
\hline quiritatus & - & MW885782 & 86206 & $\begin{array}{l}\text { 4-Cox's River, } \\
\text { Mckane's Bridge }\end{array}$ & NSW & -33.552 & 150.120 & AMS & R148134 \\
\hline quiritatus & $q$ & MW885783 & 1227 & 5-Ourimbah & NSW & -33.340 & 151.330 & AMS & R133185 \\
\hline quiritatus 5 & - & KM199719 & 1244 & 5-Ourimbah & NSW & -33.340 & 151.330 & AMS & R132687 \\
\hline quiritatus & - & MW885784 & 101713 & $\begin{array}{l}\text { 6-Boarding } \\
\text { House Dam }\end{array}$ & NSW & -33.001 & 151.404 & SAMA & R69896 \\
\hline quiritatus & - & MW885787 & 101717 & $\begin{array}{l}\text { 6-Boarding } \\
\text { House Dam }\end{array}$ & NSW & -33.001 & 151.404 & SAMA & R69897 \\
\hline quiritatus & - & MW885791 & 90470 & $\begin{array}{l}\text { 6-near Sawmill } \\
\text { Pond, Watagan } \\
\text { National Park }\end{array}$ & NSW & -33.085 & 151.355 & SAMA & R68522 \\
\hline quiritatus & - & MW885790 & 90497 & $\begin{array}{l}\text { 7-Frying } \\
\text { Pan Creek, } \\
\text { Chichester State } \\
\text { Forest }\end{array}$ & NSW & -32.330 & 151.760 & SAMA & R66161 \\
\hline quiritatus & $q$ & KM199720 & 25236 & 8-Mt Royal & NSW & -32.210 & 151.300 & SAMA & R69882 \\
\hline dentata & $\mathrm{d}$ & MW885811 & 104273 & 9-Taree & NSW & -31.900 & 152.520 & - & - \\
\hline quiritatus & $q$ & KM199719 & 25254 & $\begin{array}{l}\text { 10-Mernot State } \\
\text { Forest }\end{array}$ & NSW & -31.687 & 151.570 & - & - \\
\hline quiritatus & & - & 25272 & $\begin{array}{l}\text { 10-Mernot State } \\
\text { Forest }\end{array}$ & NSW & -31.687 & 151.570 & - & - \\
\hline quiritatus & $\mathrm{q}$ & MW885789 & 25273 & $\begin{array}{l}\text { 10-Mernot State } \\
\text { Forest }\end{array}$ & NSW & -31.687 & 151.570 & - & - \\
\hline dentata & - & KM199718 & - & $\begin{array}{l}\text { 11-Lord Howe } \\
\text { Island }\end{array}$ & NSW & -31.529 & 159.069 & - & - \\
\hline dentata & - & MW885812 & 123771 & $\begin{array}{l}\text { 12-Upper } \\
\text { Pappinbarra }\end{array}$ & NSW & -31.335 & 152.466 & - & - \\
\hline dentata & $\mathrm{d}$ & Supplementary & 141478 & $\begin{array}{l}\text { 12-Upper } \\
\text { Pappinbarra }\end{array}$ & NSW & -31.335 & 152.467 & SAMA & R69965 \\
\hline dentata & d & MW885802 & 141479 & $\begin{array}{l}\text { 12-Upper } \\
\text { Pappinbarra }\end{array}$ & NSW & -31.335 & 152.467 & - & - \\
\hline dentata & $\mathrm{d}$ & MW885809 & 25207 & $\begin{array}{l}\text { 13-Hastings } \\
\text { Forest Highway }\end{array}$ & NSW & -31.200 & 152.400 & SAMA & R69883 \\
\hline dentata & $\mathrm{d}$ & MW885807 & 141458 & $\begin{array}{l}\text { 14-Oxley Wild } \\
\text { Rivers National } \\
\text { Park }\end{array}$ & NSW & -30.813 & 152.084 & AMS & R184704 \\
\hline dentata & $\mathrm{d}$ & MW885801 & 141459 & $\begin{array}{l}\text { 14-East } \\
\text { Kunderang } \\
\text { Station, Oxley } \\
\text { Wild Rivers } \\
\text { National Park }\end{array}$ & NSW & -30.817 & 152.145 & AMS & $\mathrm{R} 184710$ \\
\hline dentata & d & - & 128585 & $\begin{array}{l}\text { 15-Newry State } \\
\text { Forest, } 30 \mathrm{~km} \\
\text { SSW Coffs } \\
\text { Harbour }\end{array}$ & NSW & -30.530 & 152.950 & - & - \\
\hline dentata & - & MW885816 & 128586 & $\begin{array}{l}\text { 15-Newry State } \\
\text { Forest, } 30 \mathrm{~km} \\
\text { SSW Coffs } \\
\text { Harbour }\end{array}$ & NSW & -30.530 & 152.950 & - & - \\
\hline
\end{tabular}

.......Continued on the next page 
TABLE 1. (continued)

\begin{tabular}{|c|c|c|c|c|c|c|c|c|c|}
\hline Taxon & $\begin{array}{l}\text { SNP } \\
\text { cluster }\end{array}$ & $N D 4$ & $\begin{array}{l}\text { ABTC } \\
\text { Number }\end{array}$ & $\begin{array}{l}\text { Locality \#/ } \\
\text { Locality }\end{array}$ & State & Latitude & Longitude & $\begin{array}{l}\text { Voucher } \\
\text { Institution }\end{array}$ & $\begin{array}{l}\text { Voucher } \\
\text { RegNum }\end{array}$ \\
\hline dentata & - & MW885800 & 128587 & $\begin{array}{l}\text { 15-Newry State } \\
\text { Forest, } 30 \mathrm{~km} \\
\text { SSW Coffs } \\
\text { Harbour }\end{array}$ & NSW & -30.530 & 152.950 & - & - \\
\hline dentata & - & Supplementary & 128588 & $\begin{array}{l}\text { 15-Newry State } \\
\text { Forest, } 30 \mathrm{~km} \\
\text { SSW Coffs } \\
\text { Harbour }\end{array}$ & NSW & -30.530 & 152.950 & - & - \\
\hline dentata & - & Supplementary & 128582 & $\begin{array}{l}\text { 16-Dorrigo, } \\
\text { public camping } \\
\text { area }\end{array}$ & NSW & -30.350 & 152.770 & - & - \\
\hline dentata & - & MW885815 & 128583 & $\begin{array}{l}\text { 16-Dorrigo, } \\
\text { public camping } \\
\text { area }\end{array}$ & NSW & -30.350 & 152.770 & - & - \\
\hline dentata & - & MW885806 & 128584 & $\begin{array}{l}\text { 16-Dorrigo, } \\
\text { public camping } \\
\text { area }\end{array}$ & NSW & -30.350 & 152.770 & - & - \\
\hline dentata & - & KM199716 & - & $\begin{array}{l}\text { 17-Coffs } \\
\text { Harbour } \\
\text { Racecourse, } \\
\text { Coffs Harbour }\end{array}$ & NSW & -30.308 & 153.127 & - & - \\
\hline dentata & - & KM199712 & - & $\begin{array}{l}\text { 18-Bananacoast } \\
\text { Caravan Park, } \\
\text { Coffs Harbour }\end{array}$ & NSW & -30.269 & 153.133 & - & - \\
\hline dentata & - & KM199717 & - & $\begin{array}{l}\text { 18-Bananacoast } \\
\text { Caravan Park, } \\
\text { Coffs Harbour }\end{array}$ & NSW & -30.269 & 153.133 & - & - \\
\hline dentata & - & KM199717 & - & $\begin{array}{l}\text { 18-Bananacoast } \\
\text { Caravan Park, } \\
\text { Coffs Harbour }\end{array}$ & NSW & -30.269 & 153.133 & - & - \\
\hline dentata & d & KM199725 & 86359 & $\begin{array}{l}\text { 19-between } \\
\text { Coutts crossing } \\
\text { and Glenreagh, } \\
\text { N Coffs Harbour }\end{array}$ & NSW & -29.928 & 152.917 & ANWC & A01777 \\
\hline dentata & - & KM199724 & 86356 & $\begin{array}{l}\text { 19-Glenreagh, N } \\
\text { Coffs Harbour }\end{array}$ & NSW & -30.050 & 152.983 & ANWC & A01757 \\
\hline dentata & d & MW885803 & 25456 & $\begin{array}{l}\text { 20-Mann River } \\
\text { Nature Reserve }\end{array}$ & NSW & -29.710 & 152.090 & SAMA & R69885 \\
\hline dentata & - & KM199721 & 25457 & $\begin{array}{l}\text { 20-Mann River } \\
\text { Nature Reserve }\end{array}$ & NSW & -29.710 & 152.090 & SAMA & R69894 \\
\hline dentata & - & KM199705 & - & $\begin{array}{l}\text { 21-McKittrick } \\
\text { Park, Grafton }\end{array}$ & NSW & -29.708 & 152.936 & - & - \\
\hline dentata & - & KM199712 & - & $\begin{array}{l}\text { 21-McKittrick } \\
\text { Park, Grafton }\end{array}$ & NSW & -29.708 & 152.936 & - & - \\
\hline dentata & - & KM199713 & - & $\begin{array}{l}\text { 21-McKittrick } \\
\text { Park, Grafton }\end{array}$ & NSW & -29.708 & 152.936 & - & - \\
\hline dentata & - & KM199714 & - & $\begin{array}{l}\text { 21-McKittrick } \\
\text { Park, Grafton }\end{array}$ & NSW & -29.708 & 152.936 & - & - \\
\hline dentata & - & KM199715 & - & $\begin{array}{l}\text { 21-McKittrick } \\
\text { Park, Grafton }\end{array}$ & NSW & -29.708 & 152.936 & - & - \\
\hline dentata & - & KM199707 & - & $\begin{array}{l}\text { 21-McKittrick } \\
\text { Park, Grafton }\end{array}$ & NSW & -29.708 & 152.936 & - & - \\
\hline
\end{tabular}


TABLE 1. (continued)

\begin{tabular}{|c|c|c|c|c|c|c|c|c|c|}
\hline Taxon & $\begin{array}{l}\text { SNP } \\
\text { cluster }\end{array}$ & ND4 & $\begin{array}{l}\text { ABTC } \\
\text { Number }\end{array}$ & $\begin{array}{l}\text { Locality \#/ } \\
\text { Locality }\end{array}$ & State & Latitude & Longitude & $\begin{array}{l}\text { Voucher } \\
\text { Institution }\end{array}$ & $\begin{array}{l}\text { Voucher } \\
\text { RegNum }\end{array}$ \\
\hline dentata & d & KM199705 & 86207 & $\begin{array}{l}\text { 22-Grafton, } 3.5 \\
\text { km N Grafton on } \\
\text { Casino Road }\end{array}$ & NSW & -29.666 & 152.938 & AMS & R151836 \\
\hline dentata & - & KM199709 & - & $\begin{array}{l}\text { 23-Palmers } \\
\text { Island, Yamba }\end{array}$ & NSW & -29.420 & 153.287 & - & - \\
\hline dentata & - & KM199710 & - & $\begin{array}{l}\text { 23-Palmers } \\
\text { Island, Yamba }\end{array}$ & NSW & -29.420 & 153.287 & - & - \\
\hline dentata & - & KM199710 & - & $\begin{array}{l}\text { 23-Palmers } \\
\text { Island, Yamba }\end{array}$ & NSW & -29.420 & 153.287 & - & - \\
\hline dentata & - & KM199711 & - & $\begin{array}{l}\text { 23-Palmers } \\
\text { Island, Yamba }\end{array}$ & NSW & -29.420 & 153.287 & - & - \\
\hline dentata & - & KM199712 & - & $\begin{array}{l}\text { 23-Palmers } \\
\text { Island, Yamba }\end{array}$ & NSW & -29.420 & 153.287 & - & - \\
\hline dentata & - & KM199715 & - & $\begin{array}{l}\text { 23-Palmers } \\
\text { Island, Yamba }\end{array}$ & NSW & -29.420 & 153.287 & - & - \\
\hline dentata & - & KM199705 & - & $\begin{array}{l}\text { 24-Lighthouse } \\
\text { Beach, Ballina }\end{array}$ & NSW & -28.869 & 153.590 & - & - \\
\hline dentata & - & KM199706 & - & $\begin{array}{l}\text { 24-Lighthouse } \\
\text { Beach, Ballina }\end{array}$ & NSW & -28.869 & 153.590 & - & - \\
\hline dentata & - & KM199705 & - & $\begin{array}{l}\text { 25-Ballina Bowl, } \\
\text { Ballina }\end{array}$ & NSW & -28.855 & 153.560 & - & - \\
\hline dentata & - & KM199705 & - & $\begin{array}{l}\text { 25-Ballina Bowl, } \\
\text { Ballina }\end{array}$ & NSW & -28.855 & 153.560 & - & - \\
\hline dentata & - & KM199707 & - & $\begin{array}{l}\text { 25-Ballina Bowl, } \\
\text { Ballina }\end{array}$ & NSW & -28.855 & 153.560 & - & - \\
\hline dentata & - & KM199708 & - & $\begin{array}{l}\text { 25-Ballina Bowl, } \\
\text { Ballina }\end{array}$ & NSW & -28.855 & 153.560 & - & - \\
\hline dentata & d & KM199722 & 25754 & $\begin{array}{l}\text { 26-Peacock } \\
\text { Creek, } \\
\text { Richmond } \\
\text { Range State } \\
\text { Forest }\end{array}$ & NSW & -28.660 & 152.710 & SAMA & R69884 \\
\hline dentata & d & KM199705 & 86376 & $\begin{array}{l}\text { 27-Dorroughby } \\
\text { Education } \\
\text { Centre, Tweed } \\
\text { Valley }\end{array}$ & NSW & -28.650 & 153.350 & ANWC & A02008 \\
\hline dentata & d & MW885799 & 141460 & 28-Kyogle & NSW & -28.618 & 153.002 & AMS & R184779 \\
\hline dentata & - & KM199707 & 25731 & $\begin{array}{l}\text { 29-Whian Whian } \\
\text { State Forest }\end{array}$ & NSW & -28.590 & 153.330 & SAMA & R69895 \\
\hline dentata & d & KM199705 & 86205 & $\begin{array}{l}\text { 30-Brunswick } \\
\text { Heads }\end{array}$ & NSW & -28.533 & 153.550 & AMS & R133486 \\
\hline dentata & d & KM199705 & 24826 & $\begin{array}{l}\text { 31-Midginbil } \\
\text { Hill }\end{array}$ & NSW & -28.502 & 153.262 & SAMA & R40185 \\
\hline dentata & d & MW885805 & 90537 & $\begin{array}{l}\text { 32-Border } \\
\text { Ranges National } \\
\text { Park }\end{array}$ & NSW & -28.400 & 153.030 & SAMA & R68578 \\
\hline dentata & - & MW885813 & 145051 & $\begin{array}{l}\text { 33-Headwaters } \\
\text { of Thane Creek, } \\
\text { Durikai State } \\
\text { Forest }\end{array}$ & Qld & -28.288 & 151.696 & QM & J96339 \\
\hline
\end{tabular}

......Continued on the next page 
TABLE 1. (continued)

\begin{tabular}{|c|c|c|c|c|c|c|c|c|c|}
\hline Taxon & $\begin{array}{l}\text { SNP } \\
\text { cluster }\end{array}$ & ND4 & $\begin{array}{l}\text { ABTC } \\
\text { Number }\end{array}$ & $\begin{array}{l}\text { Locality \#/ } \\
\text { Locality }\end{array}$ & State & Latitude & Longitude & $\begin{array}{l}\text { Voucher } \\
\text { Institution }\end{array}$ & $\begin{array}{l}\text { Voucher } \\
\text { RegNum }\end{array}$ \\
\hline dentata & - & MW885814 & 145054 & $\begin{array}{l}\text { 34-Junction } \\
\text { of Bilborough } \\
\text { Court and } \\
\text { Springbrook } \\
\text { Road, } \\
\text { Springbrook }\end{array}$ & Qld & -28.226 & 153.282 & QM & J96344 \\
\hline balatus & - & MW885796 & 145053 & $\begin{array}{l}\text { 35-Junction of } \\
\text { Upper Logan } \\
\text { and Flanagan } \\
\text { Reserve Roads, } \\
\text { Barney View }\end{array}$ & Qld & -28.225 & 152.768 & QM & J96341 \\
\hline dentata & - & MW885810 & 100638 & $\begin{array}{l}\text { 36-between } 3 \\
\text { and } 6 \text { km from } \\
\text { Goomolahra } \\
\text { Lookout, } \\
\text { Springbrook }\end{array}$ & Qld & -28.201 & 153.271 & QM & J86657 \\
\hline balatus & - & MW885795 & 145052 & $\begin{array}{l}\text { 37-Boonah- } \\
\text { Rathdowney } \\
\text { Road, about } 0.5 \\
\text { km E Burnett } \\
\text { Creek Road, } \\
\text { Maroon }\end{array}$ & Qld & -28.172 & 152.689 & QM & J96340 \\
\hline dentata & - & MW885808 & 145055 & $\begin{array}{l}\text { 38-Nerang- } \\
\text { Murwillumbah } \\
\text { Road, Numinbah } \\
\text { Valley }\end{array}$ & Qld & -28.153 & 153.225 & QM & J96347 \\
\hline balatus & $\mathrm{b}$ & Supplementary & 127795 & $\begin{array}{l}\text { 39-Ormeau } \\
\text { cemetery, } \\
\text { Ormeau }\end{array}$ & Qld & -27.805 & 153.267 & QM & J92764 \\
\hline balatus & $\mathrm{b}$ & Supplementary & 127796 & $\begin{array}{l}\text { 39-Ormeau } \\
\text { cemetery, } \\
\text { Ormeau }\end{array}$ & Qld & -27.805 & 153.267 & QM & J92765 \\
\hline balatus & - & Supplementary & 127799 & $\begin{array}{l}\text { 40-Junction of } \\
\text { Wharf Road and } \\
\text { Pimpama, Jacobs } \\
\text { Creek Road, } \\
\text { Pimpama }\end{array}$ & Qld & -27.800 & 153.293 & QM & J92768 \\
\hline balatus & - & Supplementary & 127801 & $\begin{array}{l}\text { 41-Woongoolba } \\
\text { Conservation } \\
\text { Park, } \\
\text { Woongoolba }\end{array}$ & Qld & -27.746 & 153.308 & QM & $\mathrm{J} 92770$ \\
\hline balatus & - & Supplementary & 127802 & $\begin{array}{l}\text { 41-Woongoolba } \\
\text { Conservation } \\
\text { Park, } \\
\text { Woongoolba }\end{array}$ & Qld & -27.746 & 153.308 & QM & J92771 \\
\hline balatus & - & - & 100641 & $\begin{array}{l}\text { 42-Karawatha } \\
\text { Forest Park }\end{array}$ & Qld & -27.634 & 153.095 & QM & J86660 \\
\hline balatus & $\mathrm{b}$ & MW885793 & 100642 & $\begin{array}{l}\text { 42-Karawatha } \\
\text { Forest Park }\end{array}$ & Qld & -27.634 & 153.095 & QM & J86661 \\
\hline balatus & - & - & 100643 & $\begin{array}{l}\text { 42-Karawatha } \\
\text { Forest Park }\end{array}$ & Qld & -27.634 & 153.095 & QM & J86662 \\
\hline
\end{tabular}

......Continued on the next page 
TABLE 1. (continued)

\begin{tabular}{|c|c|c|c|c|c|c|c|c|c|}
\hline Taxon & $\begin{array}{l}\text { SNP } \\
\text { cluster }\end{array}$ & $N D 4$ & $\begin{array}{l}\text { ABTC } \\
\text { Number }\end{array}$ & $\begin{array}{l}\text { Locality \#/ } \\
\text { Locality }\end{array}$ & State & Latitude & Longitude & $\begin{array}{l}\text { Voucher } \\
\text { Institution }\end{array}$ & $\begin{array}{l}\text { Voucher } \\
\text { RegNum }\end{array}$ \\
\hline balatus & - & Supplementary & 127707 & $\begin{array}{l}\text { 43-junction of } \\
\text { Moggill Road } \\
\text { and Aitcheson } \\
\text { Street, Moggill }\end{array}$ & Qld & -27.587 & 152.860 & QM & J92496 \\
\hline balatus & - & MW885797 & 127708 & $\begin{array}{l}\text { 43-junction of } \\
\text { Moggill Road } \\
\text { and Aitcheson } \\
\text { Street, Moggill }\end{array}$ & Qld & -27.587 & 152.860 & QM & J92497 \\
\hline balatus & $\mathrm{b}$ & - & 110165 & $\begin{array}{l}\text { 44-Anstead } \\
\text { Bushland } \\
\text { Reserve }\end{array}$ & Qld & -27.587 & 152.860 & QM & J91105 \\
\hline balatus & - & Supplementary & 110166 & $\begin{array}{l}\text { 44-Anstead } \\
\text { Bushland } \\
\text { Reserve }\end{array}$ & Qld & -27.541 & 152.861 & QM & J91106 \\
\hline balatus & $\mathrm{b}$ & MW885792 & 127658 & $\begin{array}{l}\text { 45-Esk- } \\
\text { Hampton Road, } \\
\text { Perseverance }\end{array}$ & Qld & -27.373 & 152.108 & QM & J93230 \\
\hline balatus & $\mathrm{b}$ & Supplementary & 127659 & $\begin{array}{l}\text { 45-Esk- } \\
\text { Hampton Road, } \\
\text { Perseverance }\end{array}$ & Qld & -27.373 & 152.108 & QM & J93231 \\
\hline balatus & - & MW885794 & 127663 & $\begin{array}{l}\text { 46-156 Zillman } \\
\text { Road, Ocean } \\
\text { View }\end{array}$ & Qld & -27.125 & 152.818 & QM & J93232 \\
\hline balatus & $\mathrm{b}$ & Supplementary & 141466 & $\begin{array}{l}\text { 47-Mount } \\
\text { Victoria } \\
\text { property, } \\
\text { adjoining Bunya } \\
\text { Mountains NP }\end{array}$ & Qld & -26.929 & 151.633 & QM & J95155 \\
\hline balatus & $\mathrm{b}$ & Supplementary & 141467 & $\begin{array}{l}\text { 47-Mount } \\
\text { Victoria } \\
\text { property, } \\
\text { adjoining Bunya } \\
\text { Mountains NP }\end{array}$ & Qld & -26.929 & 151.633 & QM & J95156 \\
\hline balatus & - & MW885798 & 145050 & $\begin{array}{l}48 \text {-West Kilcoy } \\
\text { Creek, near to } \\
\text { Conondale NP }\end{array}$ & Qld & -26.785 & 152.563 & QM & J96338 \\
\hline congenita & 79204 & MW885823 & 79204 & $\begin{array}{l}\text { Aquam Camp, } \\
\text { Trans-Fly, Papua } \\
\text { New Guinea }\end{array}$ & Western & - & - & - & - \\
\hline congenita & - & MW885817 & - & $\begin{array}{l}\text { Nenas, West } \\
\text { Timor, Indonesia }\end{array}$ & $\begin{array}{l}\text { East Nusa } \\
\text { Tenggara }\end{array}$ & -9.55 & 124.21 & WAM & R106728 \\
\hline congenita & 79184 & - & 79184 & $\begin{array}{l}\text { Wegamu, Trans- } \\
\text { Fly, Papua New } \\
\text { Guinea }\end{array}$ & Western & -8.4328 & 141.1128 & SAMA & R69842 \\
\hline electrica & - & MW885780 & 13053 & $\begin{array}{l}\text { Cumberland } \\
\text { Dam, } 20 \mathrm{~km} \mathrm{~W} \\
\text { Georgetown }\end{array}$ & Qld & -18.30 & 143.350 & - & - \\
\hline electrica & - & MW885781 & 16519 & Burketown & Qld & -17.75 & 139.55 & SAMA & R33970 \\
\hline electrica & - & KM199726 & 16521 & Burketown & Qld & -17.75 & 139.55 & SAMA & R33972 \\
\hline pygmaea & - & 100661 & 100661 & $\begin{array}{l}\text { Wondiwoi } \\
\text { Mountains, } \\
\text { Indonesia }\end{array}$ & $\begin{array}{l}\text { West } \\
\text { Papua }\end{array}$ & - & - & ZMB & 70519 \\
\hline
\end{tabular}


TABLE 1. (continued)

\begin{tabular}{|c|c|c|c|c|c|c|c|c|c|}
\hline Taxon & $\begin{array}{l}\text { SNP } \\
\text { cluster }\end{array}$ & $N D 4$ & $\begin{array}{l}\text { ABTC } \\
\text { Number }\end{array}$ & $\begin{array}{l}\text { Locality \#/ } \\
\text { Locality }\end{array}$ & State & Latitude & Longitude & $\begin{array}{l}\text { Voucher } \\
\text { Institution }\end{array}$ & $\begin{array}{l}\text { Voucher } \\
\text { RegNum }\end{array}$ \\
\hline pygmaea & - & 100665 & 100665 & $\begin{array}{l}6 \mathrm{~km} \mathrm{~N} \\
\text { Kontiunae, } \\
\text { Waira Mt, Yapen } \\
\text { Island, Indonesia }\end{array}$ & $\begin{array}{l}\text { West } \\
\text { Papua }\end{array}$ & - & - & ZMB & 62323 \\
\hline rubella & - & MW885777 & 100006 & Mt Brockman & WA & - & - & WAM & R135374 \\
\hline rubella & 127683 & MW885778 & 127683 & $\begin{array}{l}\text { Larcom Creek, S } \\
\text { Mount Larcom }\end{array}$ & Qld & -23.871 & 151.016 & QM & J90515 \\
\hline rubella & - & MW885779 & 135591 & Camballin & WA & -17.982 & 124.2 & WAM & R140793 \\
\hline rubella & - & KM199727 & 1233 & $\begin{array}{l}\text { Collaroy } \\
\text { Homestead }\end{array}$ & NSW & -31.466 & 146.65 & AMS & R132676 \\
\hline capitula & - & MW885779 & 135591 & $\begin{array}{l}\text { Latdalam, } \\
\text { Tanimbar, } \\
\text { Indonesia }\end{array}$ & Maluku & -7.983 & 131.150 & WAM & R109984 \\
\hline capitula & 135592 & - & 135592 & $\begin{array}{l}\text { Latdalam, } \\
\text { Tanimbar, } \\
\text { Indonesia }\end{array}$ & Maluku & -7.983 & 131.150 & WAM & R109985 \\
\hline amboinensis & - & MW885825 & 100658 & $\begin{array}{l}\text { Wondiwoi } \\
\text { Mountains, } \\
\text { Indonesia }\end{array}$ & $\begin{array}{l}\text { West } \\
\text { Papua }\end{array}$ & - & - & ZMB & 62090 \\
\hline darlingtoni & - & MW885822 & 43111 & $\begin{array}{l}\text { Yuro, Papua } \\
\text { New Guinea }\end{array}$ & Chimbu & -6.533 & 144.85 & AMS & R114601 \\
\hline everetti & - & MW885817 & - & $\begin{array}{l}\text { Nenas, West } \\
\text { Timor, Indonesia }\end{array}$ & $\begin{array}{l}\text { East Nusa } \\
\text { Tenggara }\end{array}$ & -9.55 & 124.21 & WAM & R106728 \\
\hline everetti & - & MW885818 & - & $\begin{array}{l}\text { Baa, Roti Island, } \\
\text { Indonesia }\end{array}$ & $\begin{array}{l}\text { East Nusa } \\
\text { Tenggara }\end{array}$ & -10.73 & 123.1 & WAM & R105676 \\
\hline peronii & - & MW885820 & 3885 & $\begin{array}{l}\text { Cooyar Creek } \\
\text { crossing, E } \\
\text { Yarraman }\end{array}$ & Qld & -26.87 & 152.03 & SAMA & R33658 \\
\hline peronii & - & MW885818 & 24187 & Ourimbah & NSW & -33.37 & 151.37 & SAMA & R33915 \\
\hline rothii & - & MW885819 & 1082 & Pinnacles & Qld & -15.68 & 143.56 & SAMA & R32540 \\
\hline rothii & - & MW885824 & 100095 & $\begin{array}{l}\text { Mount Elizabeth } \\
\text { Station }\end{array}$ & WA & -16.419 & 126.100 & WAM & R167959 \\
\hline
\end{tabular}

PartitionFinder 2 (Lanfear et al. 2017) was used to select best-fit partitioning schemes and models of nucleotide substitution using the "greedy" algorithm option and the corrected Akaike Information Criterion (AICc). Sequences were analysed phylogenetically using Bayesian and maximum likelihood methods. Bayesian analysis was conducted using MrBayes v3.1.2 (Ronquist et al. 2012). The analysis was run with model parameters unlinked using default priors for two million generations with two independent runs and two chains sampling every 1000 generations. Convergence was assessed as achieved when the average standard deviation of split frequencies was $<0.001$ and effective sample sizes (ESS) were $>200$ as determined in TRACER v1.7 (Rambaut et al. 2018). The first $25 \%$ of sampled trees were discarded as burn-in. Partitioned maximum likelihood (ML) analysis was performed using RAxML v8.0 (Stamatakis 2014) on the CIPRES Science Gateway (Miller et al. 2010).

Net average sequence divergence between lineages $(d \mathrm{~A})$ was calculated in MEGA v5 (Kumar et al. 2016) as: $d \mathrm{~A}=d \mathrm{XY}-(d \mathrm{X}+d \mathrm{Y}) / 2$, where, $d \mathrm{XY}$ is the average distance between groups $\mathrm{X}$ and $\mathrm{Y}$, and $d \mathrm{X}$ and $d \mathrm{Y}$ are the within-group mean.

Molecular diagnostics. Following the recommendation of Renner (2016), we visually identified diagnostic SNPs within the mitochondrial ND4 gene in Geneious Pro v11.1.4 (Kearse et al. 2012). Using as a reference the mitogenome from Hyla annectans (GenBank accession KM271781), we selected the apomorphic diagnostic SNPs for each species, using the other members of the Litoria rubella species group (Table 1) to assess character state polarity. 


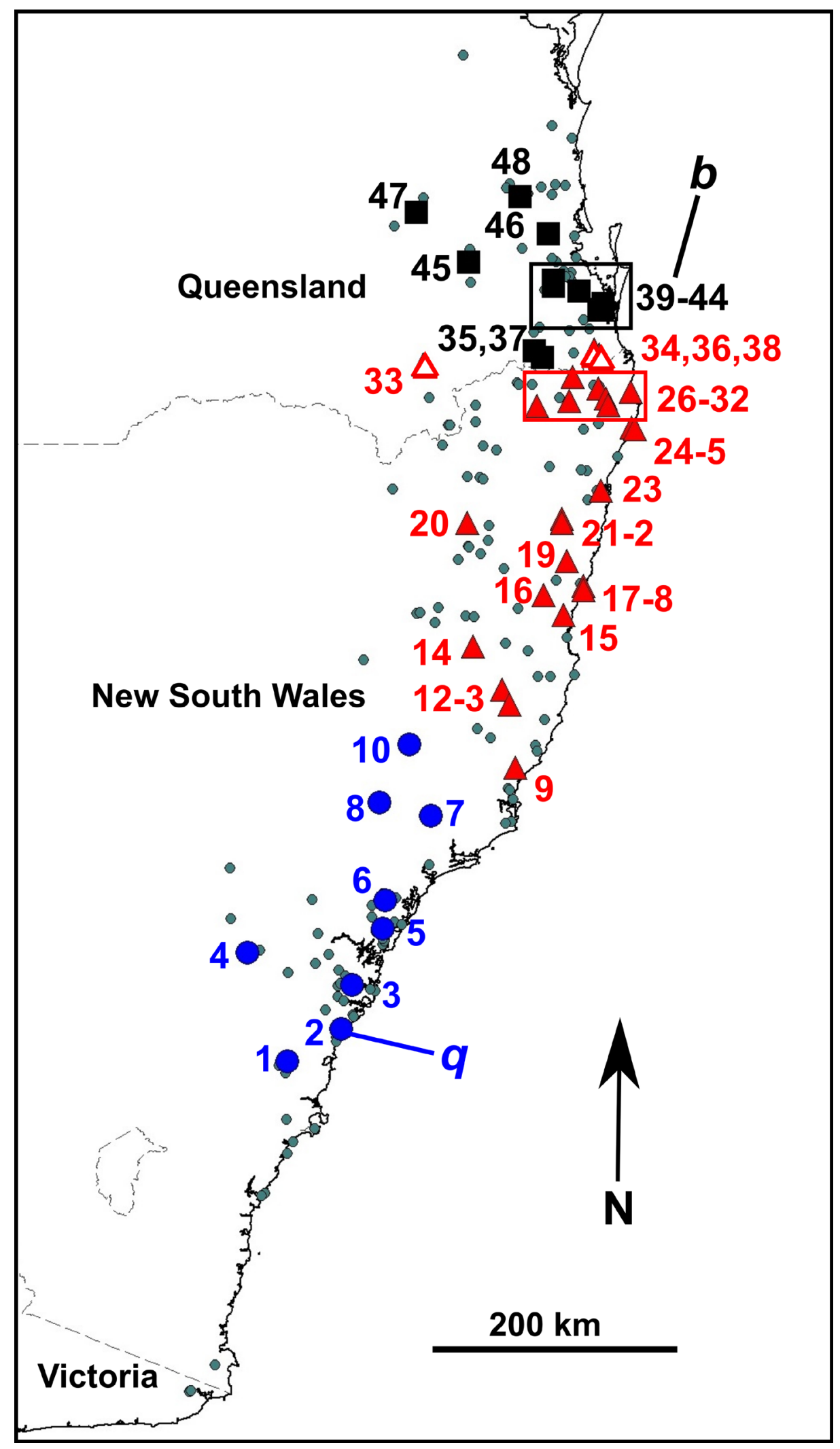

FIGURE 1. Map showing the distribution of Litoria balatus sp. nov. (black), L. dentata (red) and L. quiritatus sp. nov. (blue). Open red symbols represent locations where mitochondrial and morphological discordance was observed. Numbered symbols indicate locations where specimens analysed for molecular genetics were collected (Table 1), Lord Howe Island, where $L$. dentata is an introduced population (location 11), is not shown. Letters indicate type locations for L. balatus sp. nov. $-b$ and $L$. quiritatus sp. nov.— q. Smaller grey circles show museum voucher records from the Atlas of Living Australia (accessed January 2016). 
SNP genotyping. We submitted samples from 33 Litoria (Table 1) for DNA extraction and DArTseq ${ }^{\mathrm{TM}} 1.0$ genotyping at Diversity Arrays Technology PL, Canberra, ACT, Australia. DArTseq ${ }^{\mathrm{TM}}$ represents a combination of DArT genome complexity reduction methods and next generation sequencing platforms (Kilian et al. 2012). DNA samples were processed in restriction enzyme digestion/ligation reactions using a combination of the $P s t \mathrm{I} / \operatorname{Sph} \mathrm{I}$ restriction enzymes and ligated fragments were PCR amplified as described by Kilian et al. (2012) and Mahony et al. (2020) for single end sequencing for 77 cycles on an Illumina Hiseq2500.

The raw sequence data were converted to .fastq files using the Illumina HiSeq2500 software. Sequences generated from each lane were processed using proprietary DArT analytical pipelines. In the primary pipeline the fastq files were first processed to filter away poor-quality sequences, with application of more stringent selection criteria to the barcode region compared to the rest of the sequence. In that way the assignments of the sequences to specific samples carried in the barcode allocation step were very reliable. Sequences from each sample were collected, separated by individuals, stripped of barcodes, cleaned and filtered to include only those with a Phred score $\geq 25$. Subsequently, sequences were aligned and matched to catalogued sequences in both NCBI GenBank and DArTdb custom databases to check for viral and bacterial contamination, with any matches removed from further processing. Identical sequences are collapsed into 'fastqcall' files.

The fastqcall files are used in the secondary pipeline implementing proprietary SNP calling algorithms in DArTSoft14 ${ }^{\mathrm{TM}}$ (Diversity Arrays Technology). Low quality base calls in singleton tags in the fastqcall files were assigned correct base calls using collapsed tags with multiple members as a template. For SNP calling all tags from all libraries included in the DArTsoft 14 analysis were clustered using DArT PL's C++ algorithm at the threshold Hamming distance of $3 \mathrm{bp}$, followed by parsing of the clusters into separate SNP loci using a range of technical parameters, especially the balance of read counts for the allelic pairs. SNP markers were identified within each cluster by examining parameters calculated for each sequence across all samples-primarily average and variance of sequencing depth, the average counts for each SNP allele and the call rate (proportion of samples for which the marker is scored). Where three sequences survived filtering to this point, the two variants with the highest read depth were selected (see Georges et al. [2018] for a more detailed description of the SNP identification process). One third of samples were processed twice from DNA, using independent adaptors, to SNP calls as technical replicates. Scoring consistency (repeatability) was used as the main selection criterion for high quality/ low error rate markers. The average read depth across loci was 16.4 reads per individual per locus for reference alleles and 10.9 for SNP alleles.

The data were converted to a matrix of SNP loci by individuals, with the contents stored as integers 0 , homozygote, reference state; 1, heterozygote; and 2, homozygote for the alternate state. DNA sequences and statistics (i.e., call rate, polymorphic information content, heterozygosity, read depth, and reproducibility for all loci and individuals) are accessible from Diversity Array Technology Pty. Ltd., Canberra, Australia (Report- DFr16-2143).

We read the SNP data and associated metadata into a genlight object (\{adegenet\}, Jombart 2008) to facilitate processing with package dartR (Gruber et al. 2018) and undertook further filtering on the basis of call rate (95\% unless otherwise specified). We filtered out secondary SNPs where they occurred in a single sequenced tag, retaining only one SNP at random. We also deleted any monomorphic loci arising as a result of the removal of individuals or populations. Given the low within-population sample sizes $(n \leq 2)$, we did not filter loci for departures from HardyWeinberg equilibrium (HWE) or linkage disequilibrium.

SNP clustering analyses. To assess the genetic similarity among individuals and populations we used the principal coordinates analysis ( $\mathrm{PCoA})$ ordination method implemented in the gl.pcoa and gl.pcoa.plot functions of dartR. We used a scree plot of eigenvalues to assess the number of informative PCs to examine, based on the average percentage variation in the original variables explained by the PCs, using the gl.pcoa.scree function in dartR.

To further analyze genetic structure, we used three methods. First, we used fastSTRUCTURE v. 1.0 (Raj et al. 2014), a Bayesian model-based clustering algorithm to infer population structure from large SNP genotype datasets. Second, we used ADMIXTURE which employs maximum likelihood estimation of individual ancestries from multilocus SNP genotype datasets. It uses the same statistical model as STRUCTURE but calculates estimates much more rapidly using a fast-numerical optimization algorithm. We estimated the number of genetic clusters by running 20 independent iterations of ADMIXTURE v1.23 (Alexander et al. 2009) at each cluster (K) from 1 to 20. We used the cross-validation error to determine the best supported admixture model. Third, we used sNMF (Frichot et al. 2014). sNMF is a fast and efficient method developed for large genomic datasets that uses sparse non-negative matrix factorization to estimate admixture coefficients of individuals. In contrast to other likelihood-based methods such as STRUCTURE, sNMF does not make any model assumptions such as requiring populations to be in Hardy- 
Weinberg and linkage equilibrium. For the sNMF analyses, 1 to 17 clusters using default parameters, 30 replicates, and 100,000 iterations per replicate were used. To select the ancestry coefficient with the highest likelihood, sNMF outputs a cross-entropy score; the lowest value with no further decrease in cross-entropy represents the bestsupported value of $K$.

To determine potentially hybrid individuals, we analysed the SNP data with the program NewHybrids (Anderson \& Thompson 2002) to identify $F_{1}$ and $F_{2}$ hybrid individuals and backcross individuals with one or the other parental species. We designated parental reference individuals on the basis of the PCoA and fastSTRUCTURE genetic clustering analyses. As the NewHybrids software can only utilise 200 loci due to memory issues, we selected a subset of 200 loci that were most informative in assessing hybridization, namely loci that showed fixed differences between the parental populations, using the gl.nhybrids routine in dartR.

Divergence estimates. We used the percentage of loci showing a fixed difference for estimating divergence between populations. A fixed difference at a locus occurs when two populations share no alleles. Accumulation of fixed differences between two populations is a robust indication of lack of gene flow (Georges et al. 2018). This was achieved using gl.fixed.diff() in the dartR package. We used tloc $=0.05$, i.e. SNP allele frequencies of 95,5 and 5,95 percent will be regarded as fixed when comparing two populations at a locus. False positives may arise because of the finite sample sizes involved and the very large number of loci genotyped. Simulations, described in Georges et al. (2018), were used to estimate the expected false positive rate in pairwise comparisons.

Phylogenetic inference: SNP data set. We inferred phylogenetic relationships among the samples using the concatenated SNP data set with two phylogenetic tree-building methods suited to SNP data, SVDquartets and maximum likelihood using Litoria congenita and L. rubella as outgroups (Table 1). SVDquartets (Chifman \& Kubatko 2014) accounts for differences in the genealogical histories of individual loci and for sequence variability due to both mutational and coalescent variance. In addition, the method is rapid and results are straightforward to interpret, in contrast to other SNP-based approaches that use MCMC methods, e.g., SNAPP (Bryant et al. 2012), which can be slow for large data sets and difficult to assess convergence. A large number of quartets must be sampled to estimate phylogenetic relationships. Three independent runs of SVDquartets with sampling of 100,000 randomly selected quartets were conducted in the program PAUP* version 4.0a build 165 (Swofford 2003) to assess topological convergence, each of which included 500 bootstrap replicates.

For the maximum likelihood approach, we used IQ-tree, with the Lewis-type ascertainment bias correction, on the IQ-TREE webserver (Trifinopoulos et al. 2016). The ascertainment bias correction considers that no invariant sites are included in the data and helps reduce overestimation of tree lengths (Leaché et al. 2015). Heterozygous SNPs were coded as the appropriate IUPAC ambiguity codes. We estimated the best substitution model with ModelFinder (Kalyaanamoorthy et al. 2017) following the BIC criterion. We assessed branch support with 1000 ultrafast bootstrap pseudo-replicates (Hoang et al. 2017).

We conducted BFD* (Bayes Factor Delimitation *with genomic data) using the SNP data following Leaché et al. (2014). BFD* provides an objective method for comparing species models in a coalescent framework. Using the SNAPP (Bryant et al. 2012) plugin in BEAST2.2 (Bouckaert et al. 2014), the analysis uses path sampling to estimate a marginal likelihood value for each species model. We ran BEAST2.2 with the priors (Alpha: 1, Beta: 11.548, Lambda: 3.8163, Rate prior: gamma). We performed path sampling of 48 steps, with 100,000 MCMC generations, and 10,000 burnin generations. We ranked and compared the resulting marginal likelihood values using Bayes factors (Kass \& Raftery 1995). We calculated the Bayes factors by multiplying by two the difference in the likelihood value of each of the alternative hypotheses (Models B-D; each of three possible two taxon arrangements of the three mt lineages observed in Fig. 2) from (Model A - the three major mitochondrial lineages observed in Fig. 2).

Morphological analyses. We examined specimens held at the Australian Museum, Sydney (AMS); Australian National Wildlife Collection, CSIRO Canberra (ANWC); South Australian Museum, Adelaide (SAMA); Queensland Museum, Brisbane (QM) and Zoologisches Forschungsmuseum Alexander Koenig, Bonn, Germany (ZFMK). We measured the following traits with Vernier callipers to the nearest $0.1 \mathrm{~mm}$ from formalin-fixed, alcohol-preserved specimens following the definitions of Watters et al. (2016): SVL—snout-vent length, HW- head width; HLhead length; ED - eye diameter, EN-eye to nostril; IOD — interorbital distance, IND — internarial distance; TD - tympanum diameter, FLL — forearm length; Fin3L-longest finger $\left(3^{\text {rd }}\right)$ length, TL - tibia length; FL -foot length; HLL — hind-limb length; Toe4L - longest toe $\left(4^{\text {th }}\right)$ length, and Toe4DW - diameter of terminal disc of $4^{\text {th }}$ toe. Measurements were not available for the type of Hyla dentata (ZFMK 28808). Sex was determined from the presence of nuptial pads or by internal examination of the gonads. Males and females were analysed separately. 
To compare differences in shape between taxa, we used a multivariate linear discriminant function analysis (DFA). Male and female samples were analyzed independently. Potentially confounding variation associated with differing body sizes and allometric growth was minimised by adjusting measurements to the values they would assume if they were of a mean body size for that sex using the allometric growth equation of Thorpe (1975): $Y_{i}^{*}$ $=\log _{10} Y_{i}-b\left(\log _{10} S V L_{i}-\log _{10} S V L_{\text {mean }}\right)$, where $Y_{i}^{*}$ is the adjusted value for character $Y$ of the $i$ th specimen; $Y_{i}$ is the raw/unadjusted value for character $Y ; b$ is the mean of the regression coefficients for $Y_{i}$ against $S V L_{i}$ estimated independently for each taxon from logarithmically transformed values of $Y_{i}$ and $S V L_{i}$; $S V L_{i}$ is the measured snoutvent length (SVL) of the $i$ th specimen; and $S V L_{\text {mean }}$ is the pooled mean SVL.

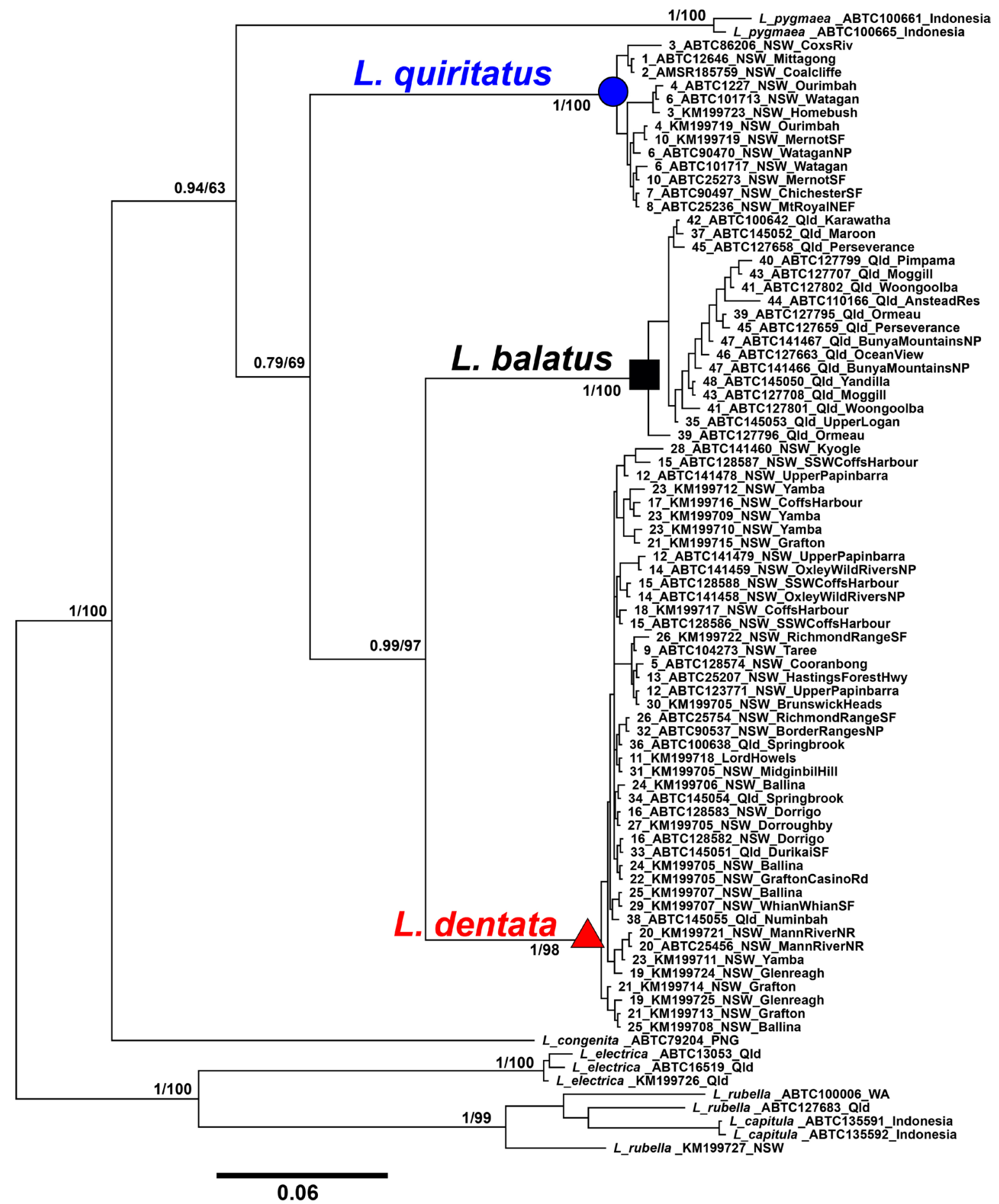

FIGURE 2. Litoria dentata sensu lato mtDNA Bayesian inference tree with Bayesian posterior probabilities (left) and ML bootstrap proportions (right) at nodes. The tree was rooted with members of the Litoria peronii species group (Table 1), which were not included here to facilitate legibility of terminal taxon names. 
We used a linear Discriminant Function Analysis (DFA) after they had been adjusted for size/growth as described above using the 'lda' function from v7.3-40 of the R package MASS in RStudio version 0.98.1028. We allocated vouchers to the three "taxa" for the DFA on the basis of their distribution relative to the genetically sampled localities, leaving out vouchers from locations close to the areas where the distributions of the genetic groups were in close proximity and taxon identity would be uncertain (13 vouchers left out of the analysis of males and four for the analysis of the females as indicated in Supplementary Table S1). The raw mensural data are presented in Supplementary Table S1.

To explore the relationship between overall morphological variation with latitude, we performed a regression for each of the sexes separately. We summarised morphological variation for all of the specimens for all morphological characters (transformed) with Principal Components Analysis (PCA), using the R function 'prcomp'.

Advertisement call analysis. We obtained male advertisement calls recorded by JJLR, HBH and MJM, contributed by colleagues or from the national citizen science project FrogID (Rowley et al. 2019, www.frogid. net.au). The latter calls were recorded via the FrogID app on smartphones. We analysed these calls in Raven Pro 1.5C (http://www.birds.cornell.edu/raven). We calculated audiospectrograms using a fast-Fourier transform (FFT) of 512 points, $50 \%$ overlap and $172 \mathrm{~Hz}$ grid-spacing, and Hanning windows. We use the definitions of Köhler et al. (2017). For up to 10 consecutive calls per call recording (=individual), we measured the call duration (s), intercall interval (s) call repetition rate (calls/s), number of pulses per call, pulse repetition rate (pulse/s), and dominant frequency $(\mathrm{kHz})$. Ambient temperature data was taken at the time for 9 of the 16 recordings made by authors, but no temperature data is submitted with FrogID calls. Therefore, for recordings obtained via FrogID, we estimated ambient temperature at the time of each recording using the 'bomrang' R (Sparks et al. 2017; Sparks et al. 2020) and 'chillR' (Luedeling 2019) packages according the methods of Mitchell et al. (2020). Three FrogID recordings did not return temperature data. For those recordings without an associated voucher specimen, we assigned molecular group based upon location; none were near contact zones between putative species. To avoid pseudoreplication, we used individuals (=recording) as the unit of replication, analysing means for each individual (Köhler et al. 2017). To investigate the relationship between call variables and taxon, we performed a non-parametric Kruskal-Wallace (KW) test for each call variable, with taxon as a factor. To identify group differences we then conducted pairwise K-W comparisons. To understand whether any of these variables were likely related to ambient temperature or latitude, we used a linear regression (for temperature, we used only the 25 recordings for which temperature was recorded or estimated). We performed all advertisement call analyses in JMP 14.

\section{Results}

We use the final specific epithets of Litoria dentata, Litoria balatus sp. nov. and Litoria quiritatus sp. nov. throughout the manuscript rather than use an initial group nomenclature that we would change to the final specific epithets in the taxonomy section. Of course, we do not assume the separate species status of the three groups within L. dentata sensu lato but rather use the results section to test this hypothesis before dealing with the final taxonomy.

Molecular genetic analyses. Our analyses of the phylogenetic relationships among the mitochondrial ND4 sequences of 74 individuals revealed three well-supported clades, L. balatus sp. nov., L. dentata and L. quiritatus sp. nov. and a well-supported sister group relationship between L. balatus sp. nov. and L. dentata (Fig. 2). Values of net average sequence divergence (dA) between the three taxa of the $L$. dentata complex in ND4 were 12, 13 and $14 \%$, all at the upper end of the range of divergences for sister species pairs in the $L$. dentata and L. peronii species groups, i.e., 3-14\% (Table 2). In addition, the two species pairs for which $16 \mathrm{~S}$ sequence data was available, L. dentata (GenBank accession number OK562702) and L. quiritatus sp. nov. (GenBank accession number FJ945379), were $3.4 \%$ divergent at the $\sim 560 \mathrm{bp}$ gene fragment analysed. This degree of pairwise divergence in the $16 \mathrm{~S}$ rRNA gene in frogs has also been interpreted as indicative of differentiation at the species level (Vences et al. 2005).

We conducted SVDQuartet phylogenetic analysis on a SNP dataset that included $L$. dentata sensu lato, $L$. congenita and L. rubella. This dataset comprised 4,217 SNPs in 33 individuals. The tree recovered the same three major lineages within $L$. dentata that were present in the mtDNA analysis (Fig. 3A). Each node in the SVDQuartet tree received 100\% support in the bootstrap analysis. Assessment of the level of divergence between the three lineages shows a high level of divergences among the three lineages, assessed by the numbers of loci showing fixed difference between the taxa (Table 3). Litoria balatus sp. nov. and L. dentata show a lower level of divergence, 
but nevertheless far higher than can be explained by sampling error (Table 3). These levels of divergence are consistent with the mtDNA and SNP maximum likelihood phylogenetic analyses and the relationships as seen in the SVDQuartets and mtDNA analyses.

TABLE 2. Net average mitochondrial ND4 sequence divergence between Litoria species. Values in bold are sister species comparisons.

\begin{tabular}{|c|c|c|c|c|c|c|c|c|c|c|c|c|c|c|}
\hline & 1 & 2 & 3 & 4 & 5 & 6 & 7 & 8 & 9 & 10 & 11 & 12 & 13 & 14 \\
\hline $\begin{array}{l}\text { 1-L.quiritatus sp. } \\
\text { nov. }\end{array}$ & - & & & & & & & & & & & & & \\
\hline 2-L. dentata & 0.13 & - & & & & & & & & & & & & \\
\hline 3-L. balatus sp. nov. & 0.14 & 0.12 & - & & & & & & & & & & & \\
\hline 4-L. electrica & 0.17 & 0.18 & 0.18 & - & & & & & & & & & & \\
\hline 5-L. rubella & 0.16 & 0.17 & 0.16 & 0.14 & - & & & & & & & & & \\
\hline 6-L, pygmaea & 0.17 & 0.16 & 0.18 & 0.22 & 0.17 & - & & & & & & & & \\
\hline 7-L. congenita & 0.16 & 0.19 & 0.18 & 0.21 & 0.16 & 0.20 & - & & & & & & & \\
\hline 8-L. darlingtoni & 0.18 & 0.21 & 0.20 & 0.22 & 0.20 & 0.21 & 0.21 & - & & & & & & \\
\hline 9-L. amboinensis & 0.20 & 0.21 & 0.20 & 0.22 & 0.20 & 0.21 & 0.21 & 0.03 & - & & & & & \\
\hline 10-L.rothii_W & 0.22 & 0.19 & 0.21 & 0.22 & 0.19 & 0.23 & 0.23 & 0.19 & 0.19 & - & & & & \\
\hline 11-L. everetti & 0.17 & 0.15 & 0.16 & 0.19 & 0.16 & 0.19 & 0.18 & 0.14 & 0.15 & 0.06 & - & & & \\
\hline 12-L.rothii_E & 0.19 & 0.18 & 0.19 & 0.21 & 0.19 & 0.22 & 0.20 & 0.17 & 0.18 & 0.10 & 0.04 & - & & \\
\hline 13-L.peronii_E & 0.19 & 0.21 & 0.19 & 0.21 & 0.18 & 0.21 & 0.20 & 0.10 & 0.10 & 0.18 & 0.13 & 0.16 & - & \\
\hline 14-L. peronii_W & 0.19 & 0.21 & 0.19 & 0.21 & 0.18 & 0.22 & 0.21 & 0.08 & 0.08 & 0.18 & 0.14 & 0.16 & 0.08 & - \\
\hline
\end{tabular}

TABLE 3. Fixed difference analysis based on pairwise comparisons of 13,843 SNP loci. Upper matrix: number of loci showing fixed differences between taxa; lower matrix: expected number of loci showing fixed differences between taxa from simulations. All comparisons were highly significant after simulation.

\begin{tabular}{llll}
\hline & L. balatus sp.nov. & L. dentata & L. quiritatus sp.nov. \\
\hline L. balatus sp.nov. & - & 831 & 4259 \\
L. dentata & 403 & - & 4041 \\
L. quiritatus sp.nov. & 690 & 571 & - \\
\hline
\end{tabular}

We also assessed the partitioning of genetic variation within $L$. dentata sensu lato using a variety of clustering methods that use a range of assumptions and models. All four clustering methods, PCoA, Admixture, sNMF, and fastSTRUCTURE delineated the same three genetic clusters with identical cluster memberships and inferred individual ancestries (Fig. 3B-C, results for sNMF and fastSTRUCTURE not shown). The three genetic clusters correspond to the three lineages recovered in the mitochondrial phylogeny and the SVDQuartet tree based on the SNPs.

Species hypotheses testing. Our analysis included 14 individuals $(6$ L. balatus sp. nov., 4 L. dentata, 4 L. quiritatus sp. nov.) and 21,464 SNP loci. We tested the following species hypotheses: (A) all major mitochondrial lineages ( $\mathrm{n}=3$ ) as separate taxa with $L$. dentata and L. balatus $\mathbf{s p . ~ n o v . ~ a s ~ s i s t e r ~ t a x a , ~ ( B ) ~ t w o ~ l i n e a g e s ~ w i t h ~ L . ~ b a l a t u s ~}$ sp. nov. and $L$. dentata lumped, (C) two lineages with $L$. quiritatus sp. nov. and $L$. dentata lumped (D) two lineages with L. balatus sp. nov. and L. quiritatus sp. nov. lumped (Table 4). Bayes Factors show decisive support for model A in which all major mitochondrial lineages are separate taxa and $L$. balatus $\mathbf{s p . ~ n o v . ~ a n d ~} L$. dentata are sister taxa.

Morphological analyses. Raw morphometric measurements of adults are summarised in Table 5. While there was a tendency for L. quiritatus sp. nov. to be slightly larger than the other two species in morphometric measurements, all measurements overlapped considerably. Therefore, for the overall comparison of morphology, we used a discriminant function analysis (DFA). We established prior group membership for specimens by choosing those that had either been genotyped or whose collection location fell within the range of each putative taxon as defined by the genotyped specimens, i.e. well away from the possible regions of contact between the taxa (Fig. 1). The male and female DFAs each returned two discriminant functions (Fig. 4). Separation of all three taxa was similar for male and female frogs. For males $(\mathrm{n}=111)$ overall predictive accuracy was $0.87(6$ L. balatus sp. nov., 7 L. dentata and $1 \mathrm{~L}$. quiritatus sp. nov. individuals misclassified) and with jack-knifed validation the classification success was 0.8 . For 
females $(\mathrm{n}=33)$ the overall predictive accuracy was $0.88(1$ L. balatus sp. nov., 2 L. dentata and 1 L. quiritatus $\mathbf{s p .}$ nov. individuals misclassified) and with jack-knifed validation the classification success was 0.71 . For males, the traits with the highest coefficients for each of the two linear discriminants were, for LD1:TL, FLL, ED and Toe4L, and for LD2: TL, HW and ED. For females, the traits with the highest coefficients for each of the two linear discriminants were for LD1: HL and FLL, and for LD2: HL and HW.

TABLE 4. Empirical results for BFD*species delimitation in Litoria dentata sensu lato.

\begin{tabular}{lcccc}
\hline & Hypothesis A & Hypothesis B & Hypothesis C & Hypothesis D \\
\hline & $(\mathrm{q}(\mathrm{d}, \mathrm{b}))$ & $(\mathrm{q}(\mathrm{d} / \mathrm{b}))$ & $(\mathrm{b}(\mathrm{d} / \mathrm{q}))$ & $(\mathrm{d}(\mathrm{b} / \mathrm{q}))$ \\
Marginal Likelihood Estimate $\left(\log _{\mathrm{e}}\right)$ & $\mathbf{- 1 3 7 8 9 5 . 4 1}$ & -180191.06 & -220367.88 & -241881.22 \\
Bayes Factor $\left(2 \times \log _{\mathrm{e}}\right)$ & NA & 84591.3 & 164944.94 & 207971.62 \\
\hline
\end{tabular}

TABLE 5. Summary of metric variation (mean $\pm \mathrm{SD}$, and range in $\mathrm{mm}$ ) in Litoria dentata sensu lato. Sample sizes are in parentheses at the head of each column next to gender ( $\mathrm{M}$ or F).

\begin{tabular}{|c|c|c|c|c|c|c|}
\hline & \multicolumn{2}{|c|}{ L. dentata } & \multicolumn{2}{|c|}{ L. balatus sp. nov. } & \multicolumn{2}{|c|}{ L. quiritatus sp. nov. } \\
\hline & M (34) & $\mathrm{F}(16)$ & M (56) & $\mathrm{F}(12)$ & M (21) & $\mathrm{F}(8)$ \\
\hline \multirow[t]{2}{*}{ SVL } & $36.7 \pm 3.8$ & $37.4 \pm 4.5$ & $34.9 \pm 3.0$ & $38.5 \pm 3.2$ & $39.2 \pm 1.7$ & $41.1 \pm 4.2$ \\
\hline & $27.8-42.4$ & $29.4-42.0$ & $26.0-43.7$ & $32.6-43.3$ & $35.8-42.5$ & $33.5-45.7$ \\
\hline \multirow[t]{2}{*}{ HL } & $9.9 \pm 1.0$ & $9.8 \pm 1.1$ & $9.8 \pm 0.9$ & $9.7 \pm 0.8$ & $11.1 \pm 0.5$ & $11.6 \pm 0.9$ \\
\hline & $8.2-11.9$ & $8.0-11.0$ & $8.2-12.7$ & $8.2-11.7$ & $10.2-11.9$ & $10.2-13.1$ \\
\hline \multirow[t]{2}{*}{ HW } & $10.3 \pm 0.9$ & $10.2 \pm 1.1$ & $10.1 \pm 0.8$ & $11.0 \pm 0.6$ & $11.3 \pm 0.6$ & $11.5 \pm 0.8$ \\
\hline & $8.5-12.6$ & $8.3-11.6$ & $8.4-12.3$ & $9.9-12.0$ & $10.3-12.9$ & $10.3-12.5$ \\
\hline \multirow[t]{2}{*}{ IND } & $2.2 \pm 0.4$ & $2.4 \pm 0.4$ & $2.3 \pm 0.2$ & $2.4 \pm 0.2$ & $2.5 \pm 0.2$ & $2.6 \pm 0.2$ \\
\hline & $1.5-2.9$ & $1.8-3.3$ & $1.8-2.8$ & $2.1-2.7$ & $2.1-2.9$ & $2.4-2.8$ \\
\hline \multirow[t]{2}{*}{ EN } & $3.2 \pm 0.3$ & $3.1 \pm 0.5$ & $3.1 \pm 0.3$ & $3.2 \pm 0.2$ & $3.4 \pm 0.3$ & $3.5 \pm 0.3$ \\
\hline & $2.1-3.7$ & $2.4-3.7$ & $2.4-4.0$ & $2.9-3.6$ & $2.5-4.2$ & $3.2-3.9$ \\
\hline \multirow[t]{2}{*}{ ED } & $3.6 \pm 0.3$ & $3.6 \pm 0.4$ & $3.4 \pm 0.4$ & $3.5 \pm 0.3$ & $3.6 \pm 0.4$ & $3.7 \pm 0.3$ \\
\hline & $3.0-4.1$ & $3.0-4.2$ & $2.8-4.3$ & $3.1-4.0$ & $3.0-4.3$ & $3.2-4.0$ \\
\hline \multirow[t]{2}{*}{ IOD } & $6.6 \pm 1.0$ & $7.0 \pm 0.7$ & $6.6 \pm 0.5$ & $7.0 \pm 0.5$ & $7.7 \pm 0.5$ & $7.8 \pm 0.6$ \\
\hline & $2.1-8.0$ & $5.9-8.1$ & $5.6-8.1$ & $6.1-7.8$ & $6.4-8.7$ & $6.9-8.9$ \\
\hline \multirow[t]{2}{*}{ TD } & $1.9 \pm 0.3$ & $1.8 \pm 0.3$ & $1.9 \pm 0.3$ & $2.0 \pm 0.4$ & $2.0 \pm 0.2$ & $2.0 \pm 0.4$ \\
\hline & $1.1-2.5$ & $1.3-2.2$ & $1.2-2.6$ & $1.6-2.9$ & $1.5-2.5$ & $1.5-2.6$ \\
\hline \multirow[t]{2}{*}{ FLL } & $7.1 \pm 0.6$ & $7.3 \pm 0.8$ & $6.5 \pm 0.7$ & $7.0 \pm 0.7$ & $8.1 \pm 0.7$ & $8.2 \pm 0.8$ \\
\hline & $5.8-8.1$ & $6.0-8.3$ & $5.1-8.2$ & $5.8-8.0$ & $7.2-9.6$ & $6.7-9.1$ \\
\hline \multirow[t]{2}{*}{ Fin3L } & $10.1 \pm 1.1$ & $10.3 \pm 1.3$ & $9.1 \pm 1.0$ & $9.9 \pm 1.2$ & $11.1 \pm 0.6$ & $11.6 \pm 1.3$ \\
\hline & $7.9-12.4$ & $8.2-11.9$ & $7.3-11.0$ & $7.9-12.2$ & $10.0-11.9$ & $9.5-13.6$ \\
\hline \multirow[t]{2}{*}{ TL } & $15.9 \pm 1.3$ & $16.7 \pm 2.1$ & $14.5 \pm 1.1$ & $15.8 \pm 1.3$ & $17.4 \pm 1.1$ & $18.1 \pm 1.7$ \\
\hline & $12.1-18.5$ & $13.1-19.0$ & $12.2-17.5$ & $13.3-17.8$ & $15.5-20.3$ & 14.9-20.3 \\
\hline \multirow[t]{2}{*}{ Toe4L } & $14.5 \pm 1.3$ & $15 \pm 1.8$ & $13.3 \pm 1.2$ & $14.5 \pm 1.5$ & $15.8 \pm 1.0$ & $16.4 \pm 1.8$ \\
\hline & $12.1-17.0$ & $12.1-17.3$ & $10.9-16.0$ & $11.8-16.7$ & $14.4-17.7$ & $13.5-18.4$ \\
\hline \multirow[t]{2}{*}{ Toe4DW } & $1.7 \pm 0.3$ & $1.6 \pm 0.3$ & $1.6 \pm 0.3$ & $1.9 \pm 0.3$ & $1.8 \pm 0.2$ & $1.9 \pm 0.5$ \\
\hline & $1.1-2.2$ & $1.2-2.1$ & $1.0-2.5$ & $1.4-2.3$ & $1.3-2.2$ & $1.4-2.7$ \\
\hline
\end{tabular}

The robustness of body shape varied substantially between the taxa, with L. balatus sp. nov. having the most slender habitus in comparison with a robust habitus in L. dentata and L. quiritatus sp. nov. (Fig. 5). Assessing the statistical significance of differences in robustness was not readily achieved in the absence of live body mass measurements, but the magnitude of variation in this trait can be assessed with a visual inspection of sexually mature males, with maturity confirmed by the presence of well-developed nuptial pads (Fig. 5).

Colour and pattern also varies among taxa. In life, the vocal sac is black in L. balatus sp. nov., black or very 
dark yellowish black when deflated and yellowish brown when inflated in L. dentata and a vocal sac that is yellow when deflated and inflated in L. quiritatus sp. nov. In addition, L. balatus sp. nov. has a distinct dorsolateral line continuing to the groin, while in $L$. dentata and L. quiritatus sp. nov. the dorsolateral line diffuses above the insertion of the arm.
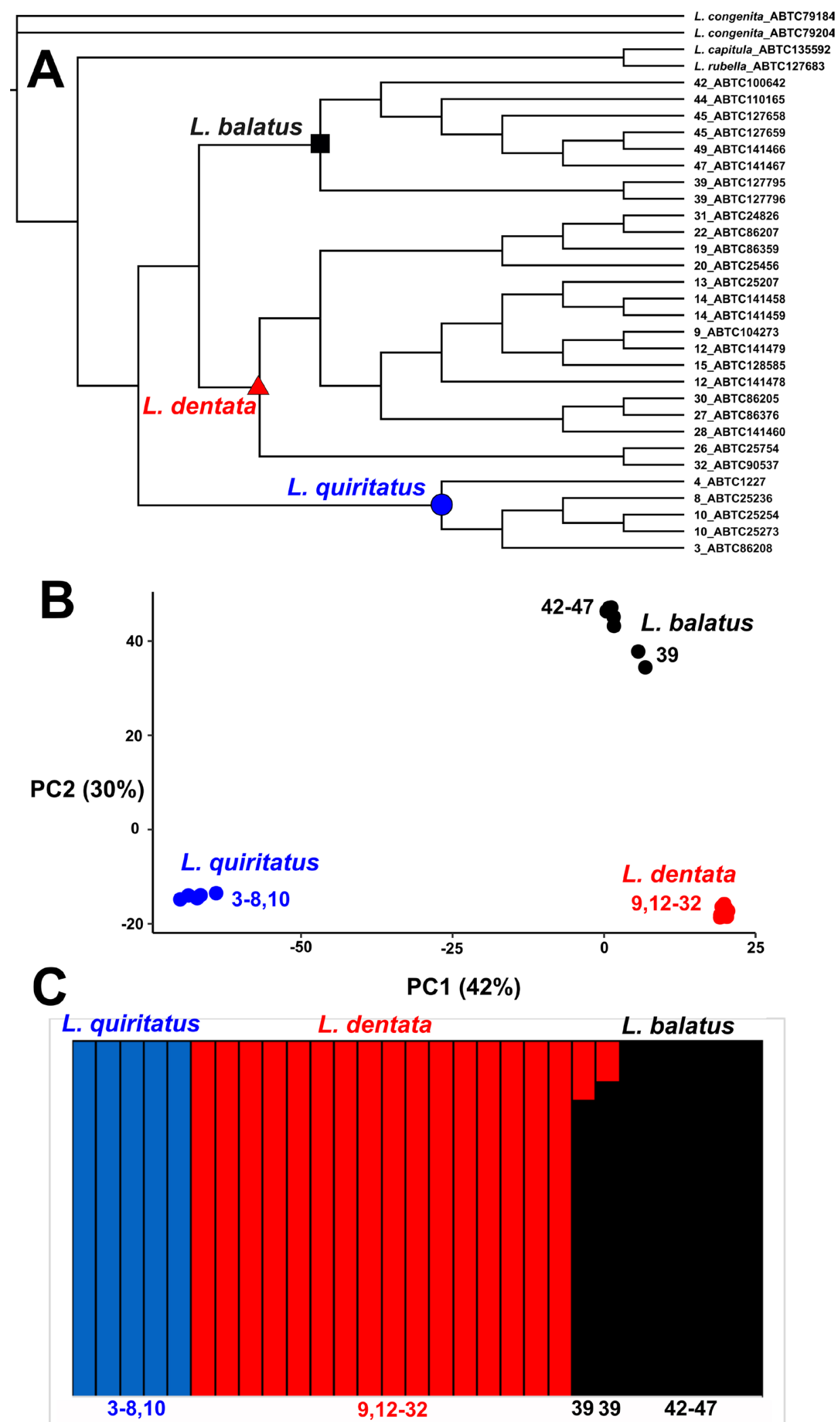

FIGURE 3. Litoria dentata sensu lato SNP analyses. A) SVDQuartets tree based on SNP data. All nodes had $100 \%$ support from bootstrapping. B-C) Clustering analyses of SNP data based on 13,831 SNPs. B) PCoA ordination with the percentage of variation explained by the first two PCs indicated, C) Admixture barplot. 


\section{Females}
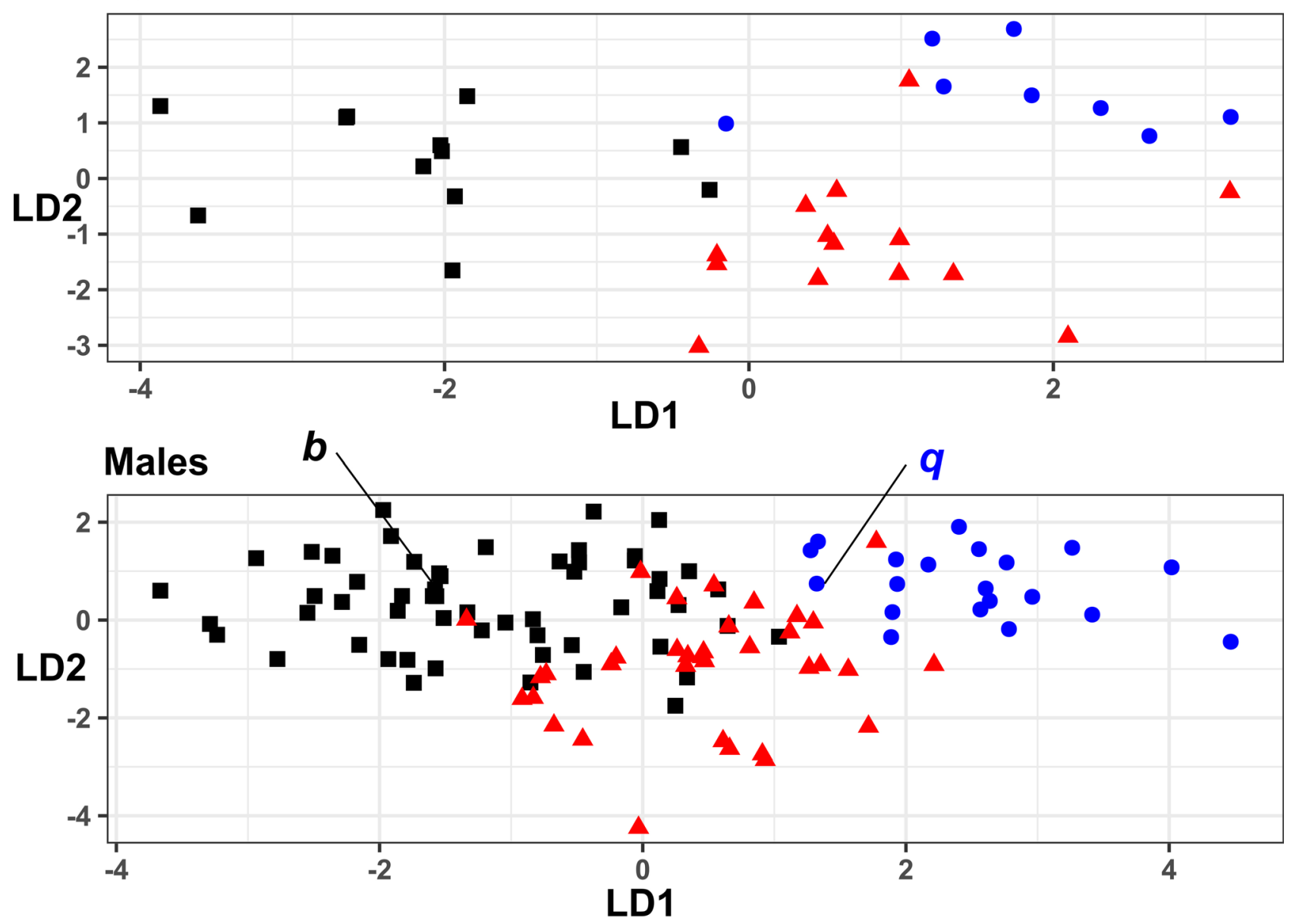

FIGURE 4. Plots of linear discriminant scores for two discriminant functions for females and males. Black squares-L. balatus sp. nov., red triangles - L. dentata and blue circles L. quiritatus sp. nov. Holotypes of L. balatus sp. nov. QM J91105 (b) and $L$. quiritatus sp. nov. AMS R185759 (q) are indicated.

We recovered a positive linear relationships between morphological measurements (PC1 and PC2) and latitude, however latitude explained relatively little variation in morphological measurements overall (none of the $\mathrm{R}^{2}$ were $>0.29)$. For PC1 there was a significant linear relationship with latitude for both females $\left(R^{2}=0.28, F_{1,36}=13.99\right.$; $\mathrm{P}=0.0006)$ and males $\left(\mathrm{R}^{2}=0.29, \mathrm{~F}_{1,121}=50.32 ; \mathrm{P}<<0.0001\right)$ (Supplementary Fig. $\left.\mathrm{S} 1\right)$. For PC2 there was a significant positive linear relationship with latitude for males $\left(\mathrm{R}^{2}=0.07, \mathrm{~F}_{1,121}=9.61 ; \mathrm{P}=0.002\right)$ but not for females $\left(\mathrm{R}^{2}=0.01\right.$, $\left.\mathrm{F}_{1,36}=0.501 ; \mathrm{P}=0.48\right)$.

Evidence of introgression. We found evidence of mitochondrial introgression (based on admixed mtDNA and morphology [body habitus]) between $L$. balatus sp. nov. and $L$. dentata in a narrow zone of $83 \mathrm{~km}$ in width at the margin of each taxon's adjacent distributions in the NSW/Queensland border area (Fig. 7). Although NewHybrids analysis of the SNP data did not detect any current hybrid individuals outside of this area (Supplementary Table S2), we did not have any SNP data for individuals with the discordance between mtDNA and body habitus.

Advertisement call analysis. We analysed the male advertisement calls of 33 individuals of Litoria dentata ( $\mathrm{n}=9)$, L. quiritatus sp. nov. $(\mathrm{n}=16)$ and L. balatus sp. nov. $(\mathrm{n}=8)$ (Table 6). Calls of the three species are in similar structure (Fig. 6), and most measured values overlapped slightly. However, there were significant differences in call duration (Chi-square $=6.8, \mathrm{P}=0.034$ ), average number of pulses per call (Chi-square $=19.7 ; \mathrm{P}<0.001$ ), average pulse repetition rate $($ Chi-square $=18.0 ; \mathrm{P}<0.001)$ and average dominant frequency $($ Chi-square $=8.6 ; \mathrm{P}<0.013)$ among species (Fig. 8).

The advertisement call of $L$. balatus sp. nov. was most distinct from the other species, having a higher average number of pulses ( $45-77$ pulses) compared to $L$. dentata ( $44-53$ pulses; $\mathrm{Z}=-2.6 ; \mathrm{P}=0.008$ ) and L. quiritatus sp. nov. (24-51 pulses; $\mathrm{Z}=-3.7 ; \mathrm{P}<0.001)$ and a higher pulse repetition rate (57-89 pulses/s) compared to $L$. dentata (37-57 
pulses/s; $\mathrm{Z}=-3.4 ; \mathrm{P}<0.001)$ and $L$. quiritatus sp. nov. $(30-53$ pulses $/ \mathrm{s} ; \mathrm{Z}=-3.8 ; \mathrm{P}<0.001)$. The average dominant frequency of $L$. balatus sp. nov. $(3.4-4.3 \mathrm{kHz})$ was also significantly higher than in $L$. dentata $(2.9-4.0 \mathrm{kHz} ; \mathrm{Z}=2.6$; $\mathrm{P}=0.009$ ) (Table 6). Although values overlapped considerably, the call of L. balatus sp. nov. was also typically shorter $(0.63-1.12 \mathrm{~s})$ than $L$. dentata $(0.84-1.33 \mathrm{~s} ; \mathrm{Z}=2.6, \mathrm{P}=0.237)$ and L. quiritatus sp. nov. $(0.70-1.31 \mathrm{~s} ; \mathrm{Z}=2.0$, $\mathrm{P}=0.243$ ).

In contrast, the advertisement call of $L$. quiritatus sp. nov. had a lower average number of pulses per call (24-51 pulses) compared to $L$. dentata (44-53 pulses; $\mathrm{Z}=-3.0 ; \mathrm{P}=0.003$ ) and L. balatus sp. nov. (45-77 pulses; $\mathrm{Z}=-3.7 ; \mathrm{P}<0.001$ ), a lower average pulse repetition rate (30-53 pulses/s) compared to L. balatus $\mathbf{s p}$. nov. (57-89 pulses $/ \mathrm{s} ; \mathrm{Z}=-3.8 ; \mathrm{P}<0.001)$ and a slightly higher average dominant frequency $(3.1-4.1 \mathrm{kHz})$ compared to $L$. dentata (2.9-4.0kHz; $\mathrm{Z}=-2.6 ; \mathrm{P}=0.009$ ).
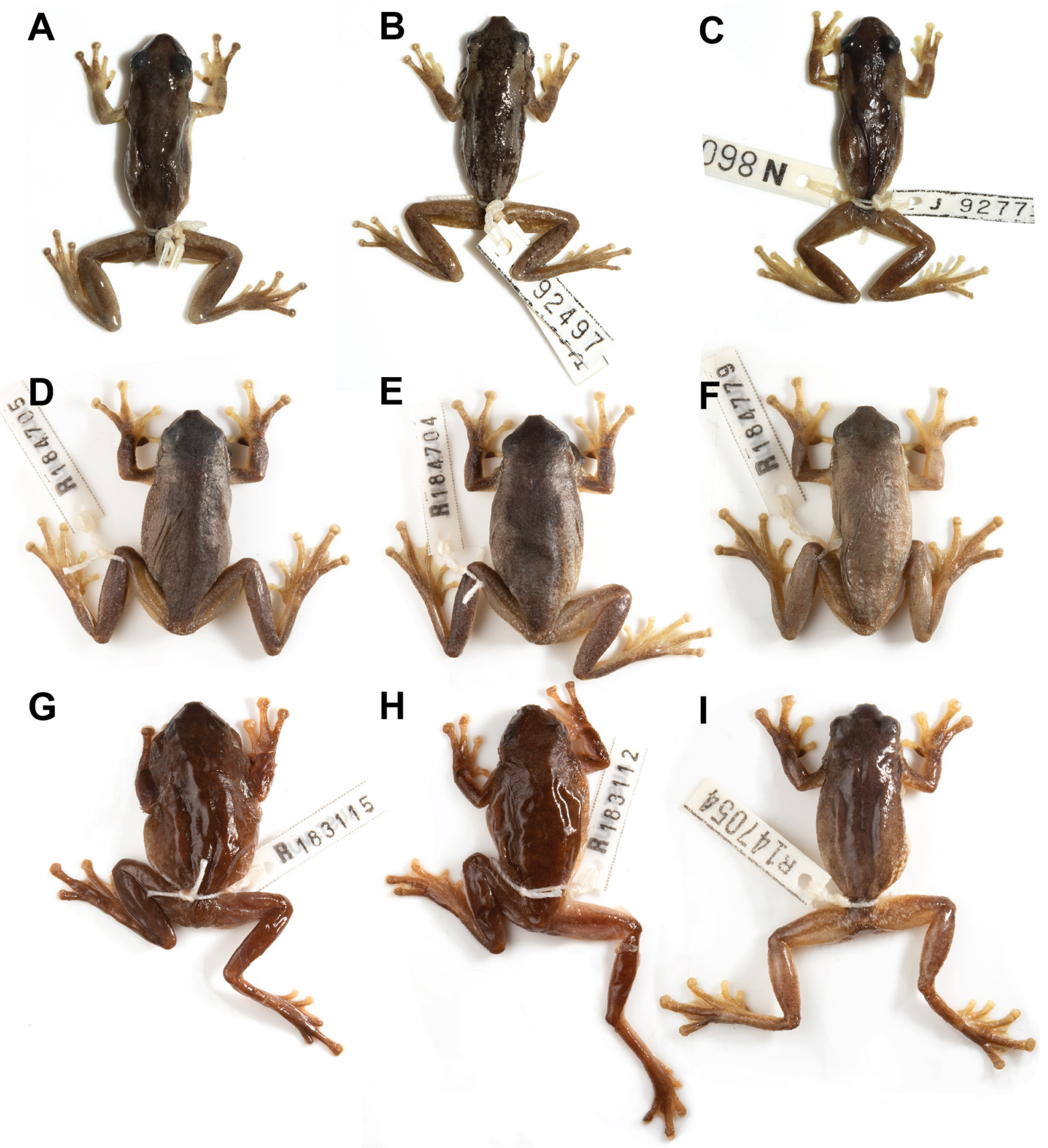

FIGURE 5. Body shape in sexually mature males. Litoria balatus sp. nov. A-C) QM J92768, Ormeau Hills, Q1d, J92497, Moggill, Qld and J92771, Woongoolba Conservation Park, Qld; L. dentata D-F) AMS R184705 and R184704, Oxley Wild Rivers National Park, NSW; AMS R184779, Kyogle, NSW, and L. quiritatus sp. nov. G-I) AMS R183115 and R183112, Ourimbah Creek Road, NSW; AMS R147054, Homebush Bay, NSW. Images were scaled to the same snout-vent length to facilitate comparisons. 

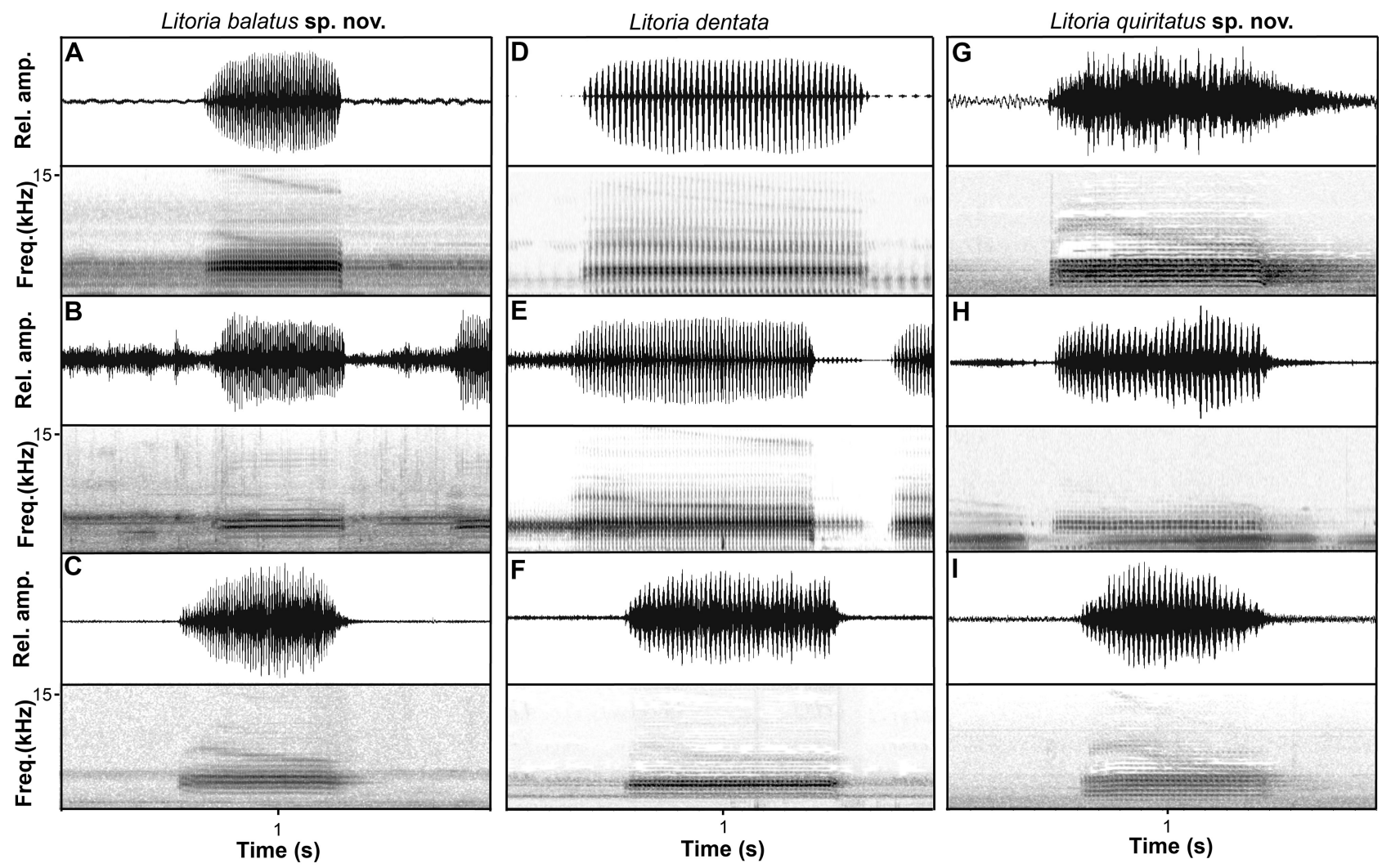

FIGURE 6. Call variation in Litoria balatus sp. nov., L. dentata and L. quiritatus sp. nov. Advertisement calls displayed as a $2 \mathrm{~s}$ waveform of relative amplitude (Rel. amp.) over time and corresponding spectrogram of frequency (Freq.) over time. The recorder of each call is listed in Table 6. Litoria balatus sp. nov.-A) holotype QM J91105, Anstead Bushland Reserve, Anstead, Qld $\left.\left(21^{\circ} \mathrm{C}\right), \mathbf{B}\right)$ Karawatha Forest, Brisbane, Qld $\left.\left(24.5^{\circ} \mathrm{C}\right), \mathbf{C}\right)$ FrogID capture 12633, Witta, Qld; L. dentata-D) AMS R184704, Oxley Wild Rivers National Park, NSW $\left(18.5^{\circ} \mathrm{C}\right)$, E) AMS R184779, Kyogle, NSW $\left(20.8^{\circ} \mathrm{C}\right)$, F) FrogID capture 6860, Cawongla, NSW; L. quiritatus sp. nov.-G) holotype AMS R185759, Coalcliff, NSW, H) not vouchered, Ourimbah NSW $\left.\left(22.8^{\circ} \mathrm{C}\right), \mathbf{I}\right)$ FrogID capture 10260, Surf Beach, NSW.

We found a negative linear relationship between temperature and call duration $\left(\mathrm{R}^{2}=0.46, \mathrm{~F}_{1.22}=18.9 ; \mathrm{P}<0.001\right)$, and a positive linear relationship between temperature and pulse repetition rate $\left(\mathrm{R}^{2}=0.35, \mathrm{~F}_{1,21}=11.3 ; \mathrm{P}=0.003\right)$ and dominant frequency $\left(\mathrm{R}^{2}=0.27, \mathrm{~F}_{1,22}=8.05 ; \mathrm{P}=0.009\right)$. The number of pulses per call did not vary significantly with temperature $\left(\mathrm{R}^{2}=0.02, \mathrm{~F}_{1,21}=0.51, \mathrm{df}=21 ; \mathrm{P}=0.48\right)$. Across a range of temperatures, the calls of L. balatus sp. nov. had a consistently higher average number of pulses per call and pulse repetition rate (Fig. 8).

We detected a significant positive linear relationship between latitude and the number of pulses per call $\left(\mathrm{R}^{2}=0.62\right.$, $\left.\mathrm{F}_{1,29}=46.36 ; \mathrm{P}<0.001\right)$ and pulse repetition rate $\left(\mathrm{R}^{2}=0.53, \mathrm{~F}_{1,29}=33.66 ; \mathrm{P}<0.001\right)$, but not with call duration $\left(\mathrm{R}^{2}=0.06\right.$, $\left.\mathrm{F}_{1,31}=1.88 ; \mathrm{P}=0.18\right)$ or dominant frequency $\left(\mathrm{R}^{2}=0.02, \mathrm{~F}_{1,31}=0.52 ; \mathrm{P}=0.48\right)$ (Supplementary Fig. S2).

Systematic implications. We conclude that $L$. dentata comprises three lineages that constitute separate species under the evolutionary species concept (sensu de Queiroz 1998). Our arguments are based on:

1. the presence of three well-supported reciprocally monophyletic mitochondrial groups within $L$. dentata sensu lato;

2. a level of sequence divergence for the ND4 mitochondrial gene between the taxa (12-14\%) that is very similar to other well accepted sister species pairs of Litoria (Table 2);

3. fully concordant nuclear and mitochondrial groups and relationships for the proposed species boundaries;

4. Bayes factor species delimitation strongly favouring the three species hypothesis;

5. no further concordant nuclear and mitochondrial genetic structuring within any of the proposed taxa;

6. representative sampling across the range of each proposed taxon (a combined total distance of $>890 \mathrm{~km}$ north to south). We have sampled $L$. dentata and L. quiritatus sp. nov. in close proximity within $83 \mathrm{~km}$ of each other at locality 9 and locality 10 respectively without evidence of introgression. 


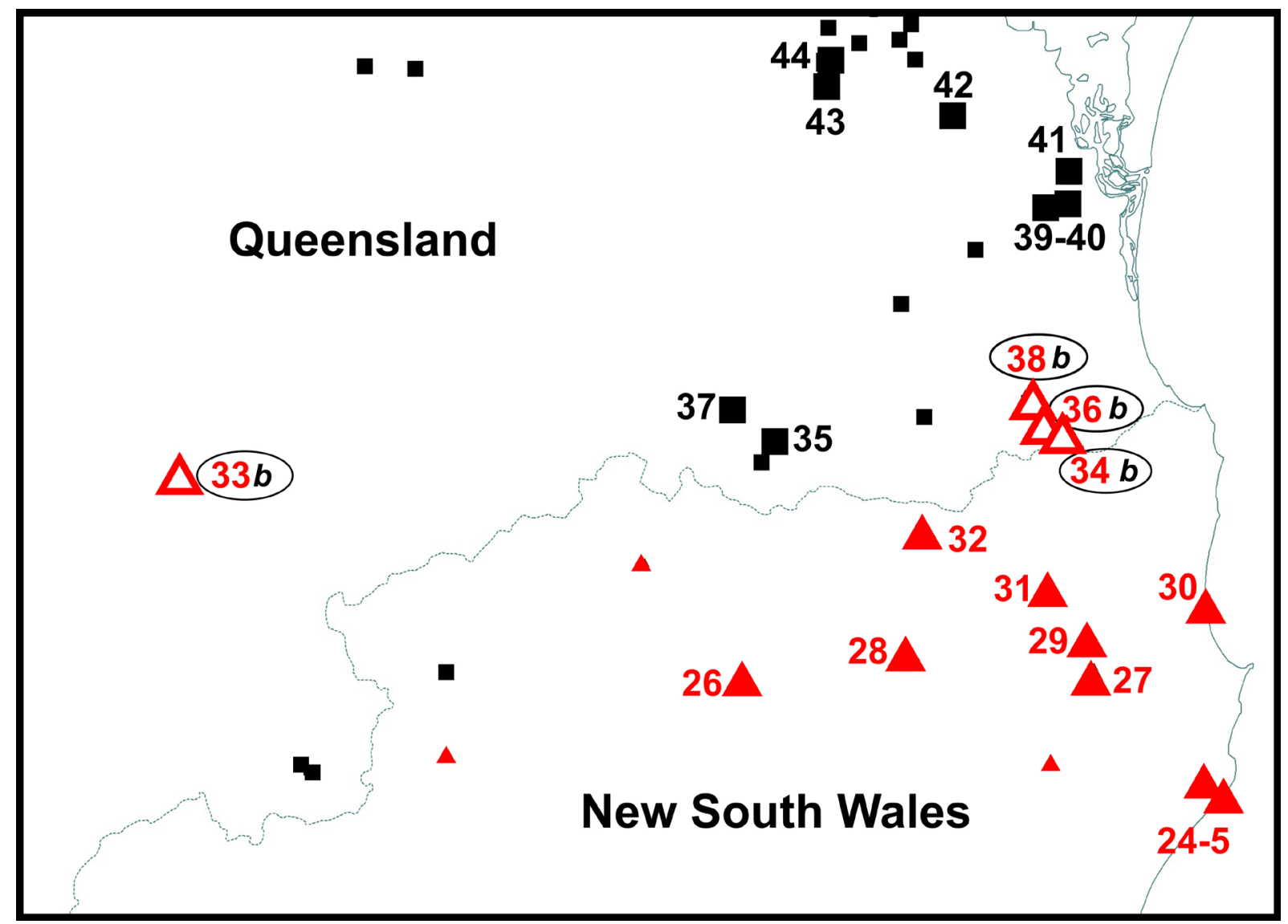

FIGURE 7. Map showing sampling detail in south-eastern Queensland and north-eastern NSW. Symbols show mtDNA clade (black squares - L. balatus sp. nov., red triangles - L. dentata), letters show the morphological group (b-L. balatus sp. nov.). Hollow red triangle symbols indicate locations [33, 34, 36, 38] with evidence of mitochondrial introgression. Numbers indicate locations where specimens analysed for molecular genetics were collected (Table 1). Small symbols are ALA voucher records assigned to each species.
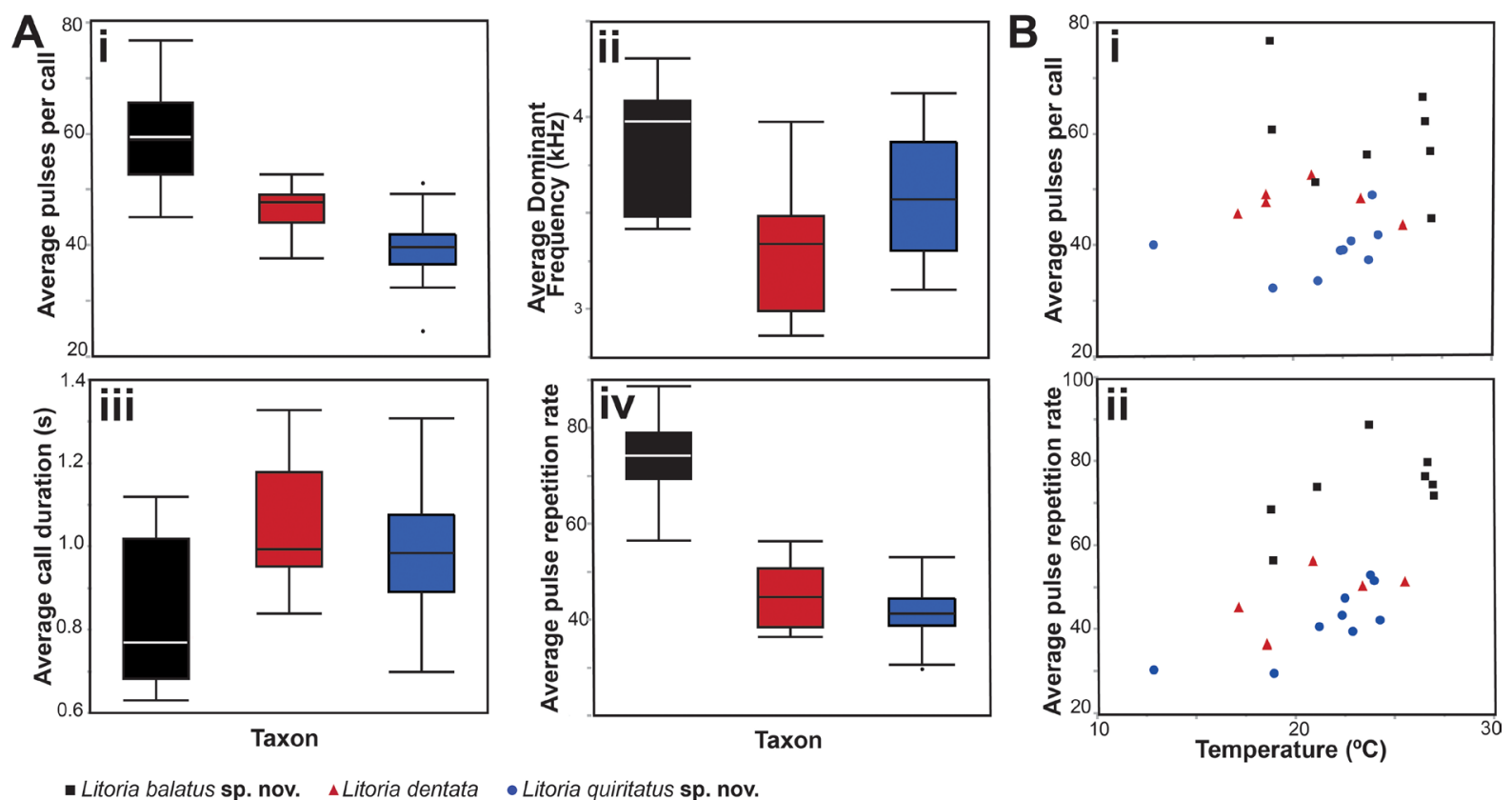

FIGURE 8. Variation in advertisement calls traits in Litoria balatus sp. nov., L. dentata and L. quiritatus sp. nov. A) Boxplots of i) Average pulses per call, ii) average dominant frequency ( $\mathrm{kHz}$ ), iii) average call duration (s) and iv) average pulse repetition rate (pulses/s) in, and B) i) Average pulses per call and ii) average pulse repetition rate (pulses/s) with ambient temperature. 


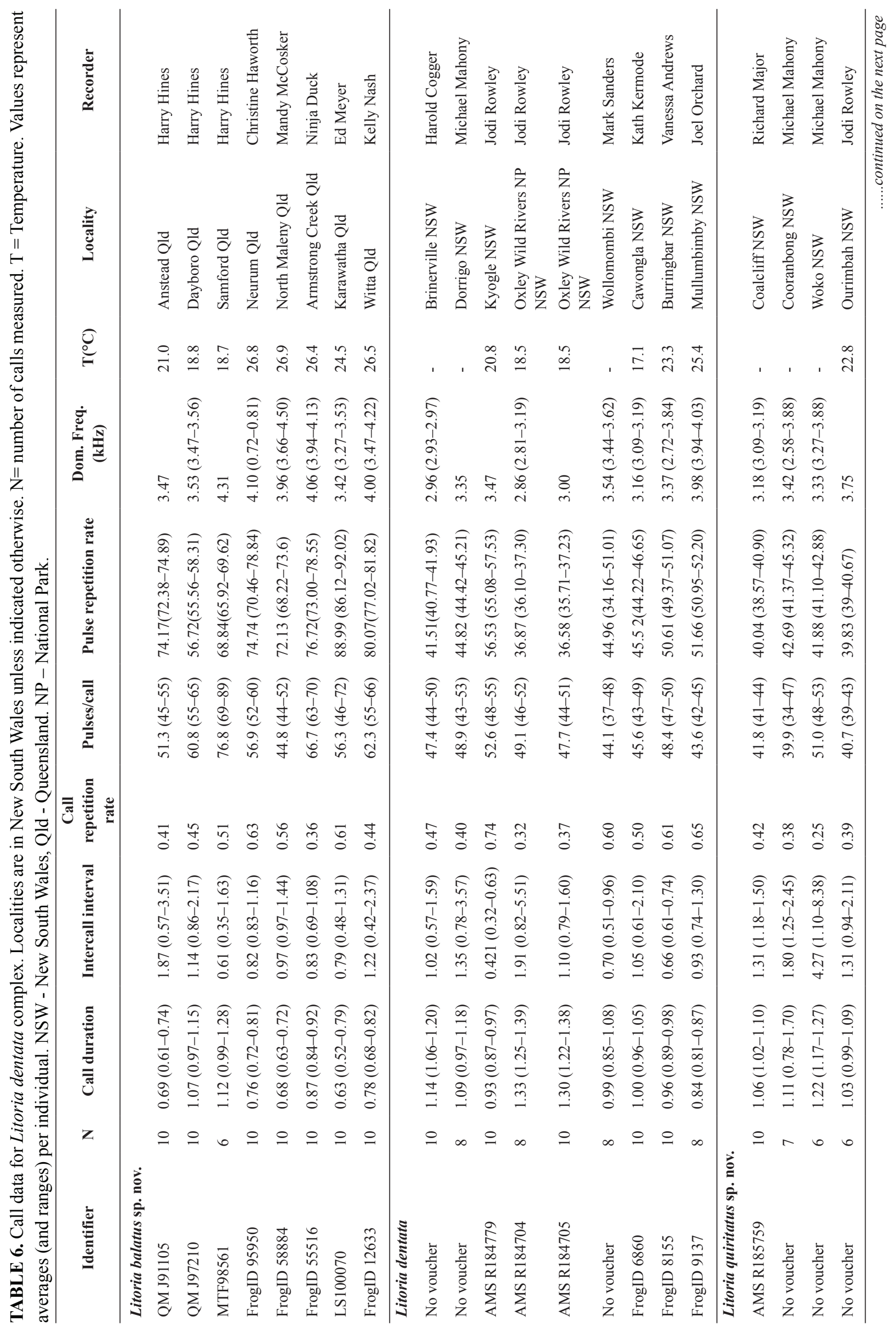




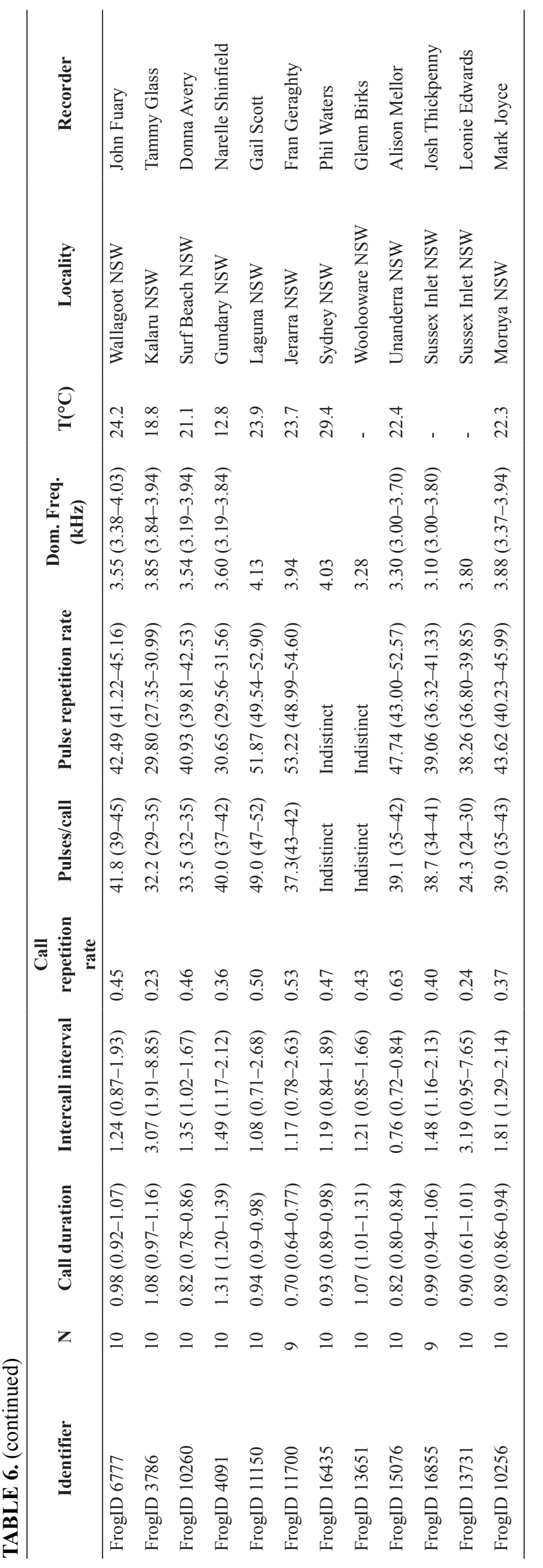


Determining the extent of and the evidence for mitochondrial introgression at the shared range margins of the three species, particularly L. balatus sp. nov. and L. dentata in south-eastern Queensland and north-eastern NSW was limited by the availability of molecular characterised male specimens. Discordance between mitochondrial DNA and nuclear genes and/or nuclear gene encoded phenotypic traits can result from introgression of mtDNA from a closely related lineage without any evidence of substantial gene flow between nuclear genomes (Toews \& Brelsford 2012). Nevertheless, our data at a minimum support mitochondrial introgression in this narrow region, but further sampling with nuclear markers would be required to eliminate other more genome wide expansive introgression scenarios.

Furthermore, divergence in body shape, in colouration (inflated vocal sac colouration and whether the dorsolateral line continues to the groin or diffuses at the insertion of the arm) and in the male advertisement call, particularly between $L$. balatus sp. nov. and both $L$. dentata and L. quiritatus sp. nov., support the recognition of three species. We note that the divergence in morphology and male advertisement calls is greatest between the two phylogenetically closest taxa: L. balatus sp. nov. and L. dentata. Variation in overall body shape and properties of the male advertisement call are weakly correlated with latitude (Supplementary Fig. S1), and do not show evidence of stepped clines, consistent with the slight morphological differentiation of the taxa in this species complex.

We did not designate paratypes for either of the new species described herein however all specimens examined are listed in Supplementary Table S1.

\section{Taxonomy.}

Diagnosis. Litoria dentata, L. balatus sp. nov. and L. quiritatus sp. nov. share the following features of the Litoria rubella species group sensu Tyler \& Davies (1978, 1983): squat, small to medium frogs, maximum length $46 \mathrm{~mm}$. Fingers short, broadly fringed, webbed at least at the base; hindlimbs short, toes webbed at least at the base. Dorsum usually brown or grey, with paler or darker, longitudinally orientated stripes; several species exhibit dark lateral stripes on the head and body. Pupil rhomboidal when contracted (Supplementary Table S1). Species in the group breed in static water and have small, pigmented ova. All three taxa also fall within the Litoria rubella species group according to the mitochondrial phylogenetic analyses presented herein and in the more comprehensive mtDNA survey in Rosauer et al. (2009).

Provenance of the holotype of Hyla dentata. The collection location for the type of Hyla dentata Keferstein 1868 is stated as "Neu-Süd-Wales" (i.e. New South Wales) in the type description. GMS investigated the provenance of ZFMK 28808 (see Appendix), and concluded that it is likely that the type of Hyla dentata was collected from within the range of the central lineage.

\section{Litoria dentata (Keferstein 1868)}

Robust Bleating Tree Frog

Hyla dentata Keferstein W. 1868. Über die Batrachier Australiens. Archiv für Naturgeschichte Berlin 34, 253-290 [284].

Figs 9, 10

Holotype. ZFMK 28808 (ex Zoologischen Museums Greifswald (ZMG) specimen ZMG 123a), from New South Wales (NSW), Australia.

The type does not have any nuptial pads, which are visible in both breeding and non-breeding adult male Litoria dentata, and therefore is likely to be a female. According to Harold Cogger (pers. comm.) the SVL of the holotype $(41 \mathrm{~mm})$ differs from that given in the original description (Körper = body $29 \mathrm{~mm}$; Keferstein 1868) suggesting that the length stated in the original description was erroneous.

Material examined. See Supplementary Table S1 for details of all material examined.

Revised diagnosis. Litoria dentata is distinguished from all species in the Litoria rubella group by a combination of (1) adult body size $28-42 \mathrm{~mm}$ in males and $29-42 \mathrm{~mm}$ in females, (2) relatively robust build, (3) the presence of a single, continuous, irregularly edged, dark brown dorsal band, (4) the absence of light spots on the dorsum, (5) lack of a well-defined pale mid-dorsal stripe, (6) absence of distinctive pale markings above the groin, vent and along 
lower leg, (7) a dorsolateral line diffusing above insertion of the arm, and (8) adult males having a vocal sac that is black or very dark yellowish black when deflated and yellowish brown when inflated.

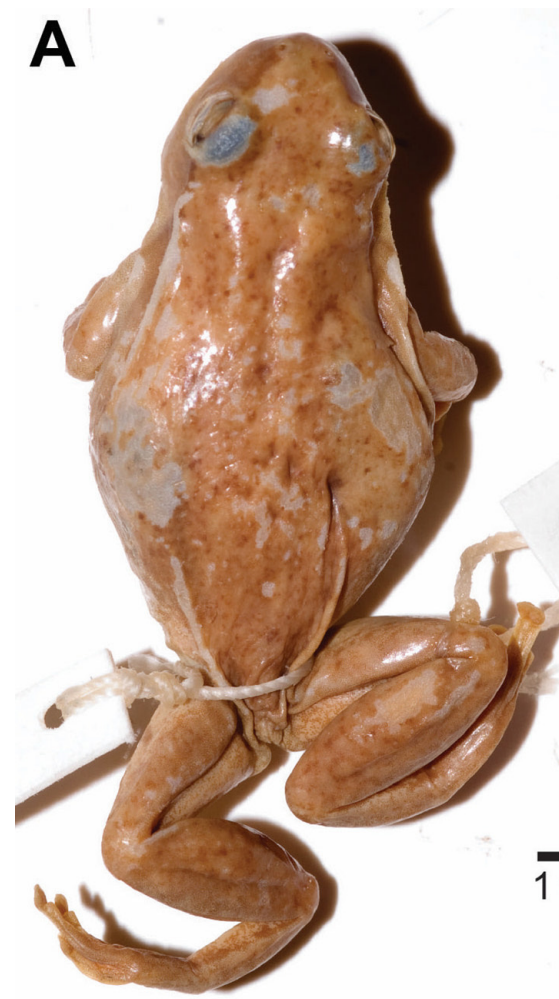

C

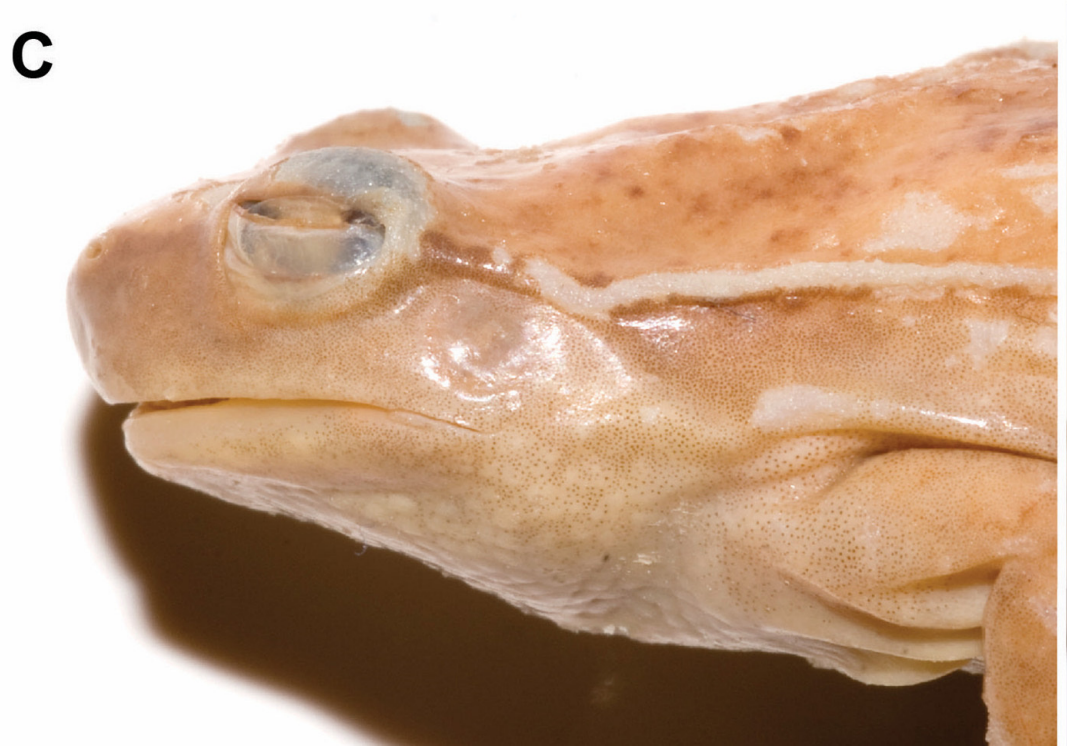

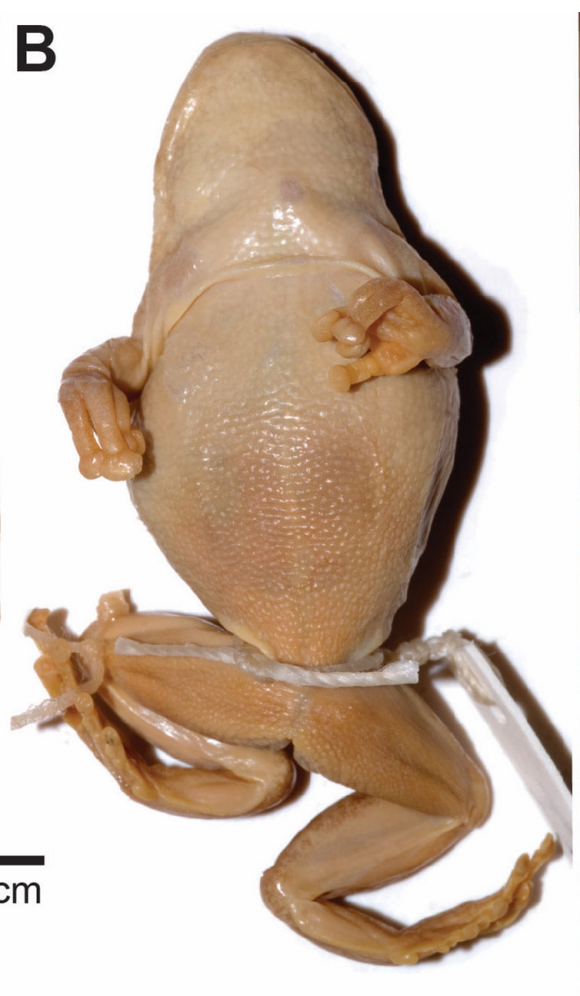
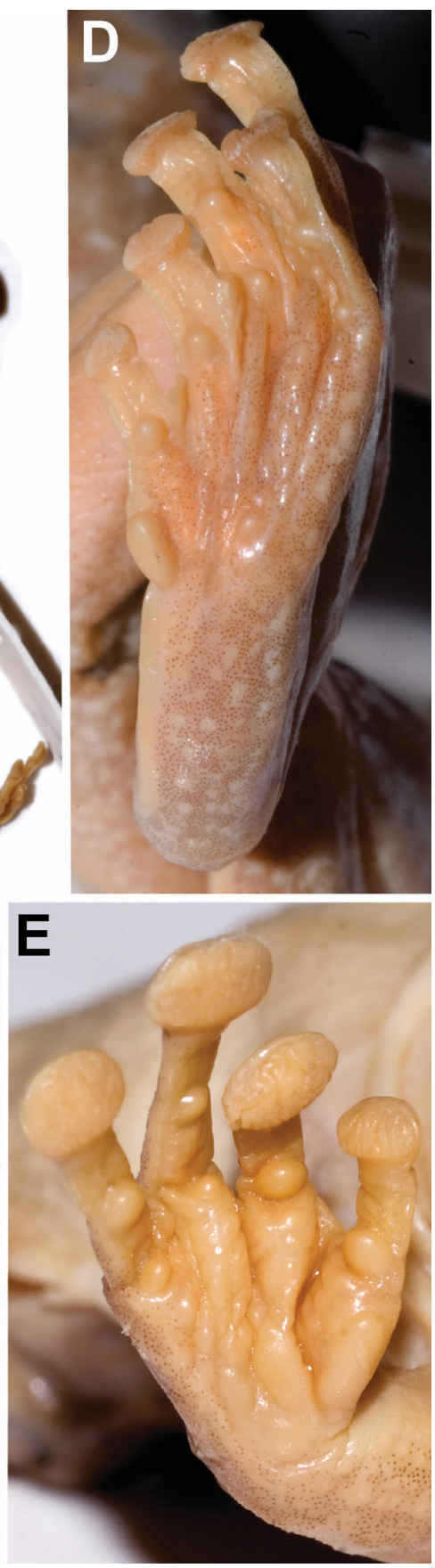

FIGURE 9. Holotype of Hyla dentata A) dorsal, B) ventral, C) lateral view of head, D) palmar view of hand, and E) plantar view of foot.

Redescription of holotype. We redescribe the holotype from high quality images of the preserved specimen. SVL $41 \mathrm{~mm}$ (Cogger pers. comm.). Habitus relatively robust; head widest at eyes, slightly longer than wide; snout rounded in lateral view and bluntly rounded in dorsal view (Fig. 9); nostrils prominent in dorsal profile; tympanum circular and clearly visible. Legs short; fingers and toes with prominent terminal discs, fingers with basal webbing, toes half webbed; sub-articular tubercles prominent; nuptial pads absent; inner metatarsal tubercle prominent, approximately one third of the length of first toe. Pectoral fold present. Venter coarsely granular, especially posteriorly; dorsum smooth. Colour in life not described in original description by Keferstein (1868). Colour after more than 150 years of preservation medium brown dorsally, creamy yellowish brown ventrally, finely stippled dark brown laterally, with paler patches on dorsum and a pale dorsolateral stripe (Fig. 9). 

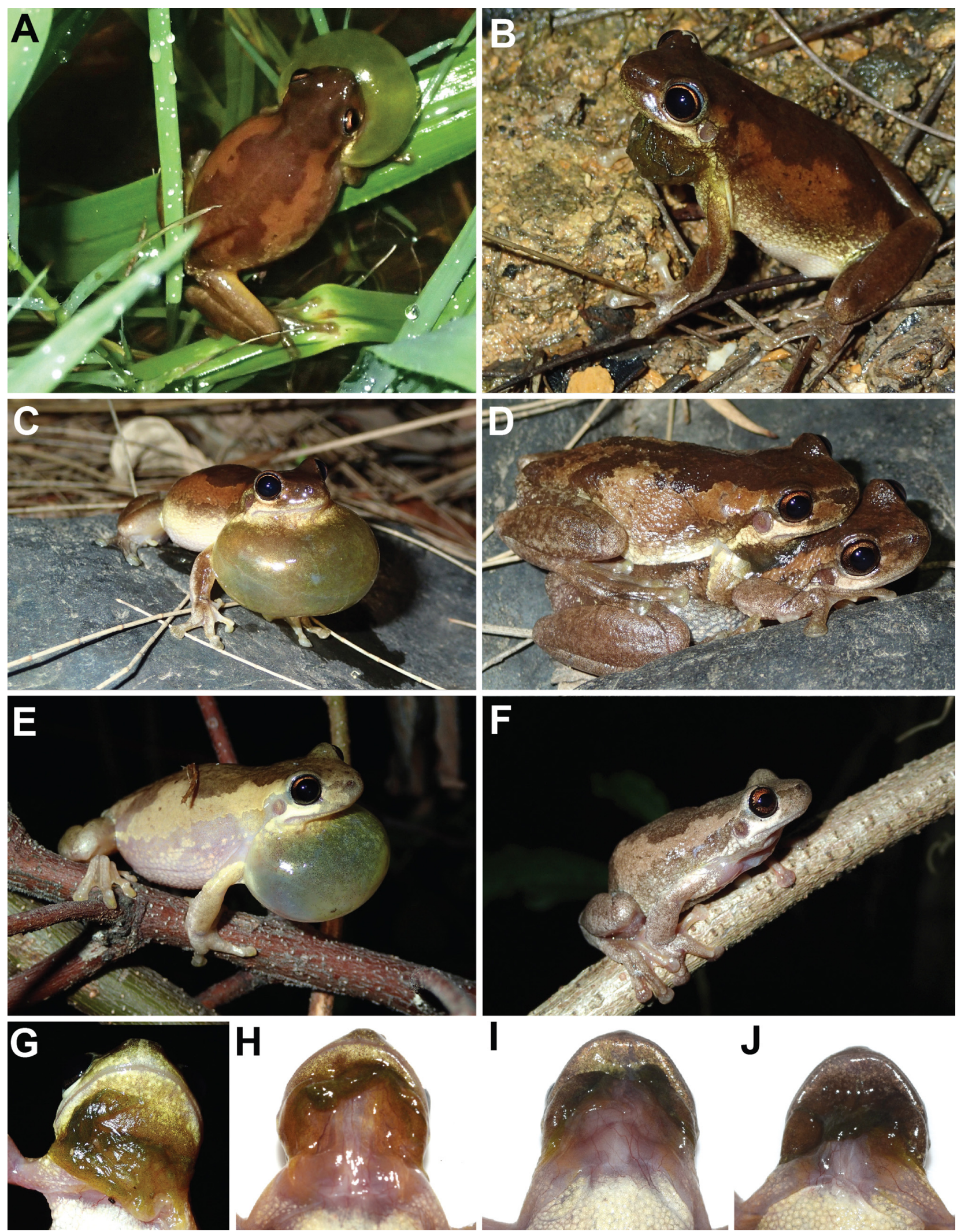

FIGURE 10. Images in life of Litoria dentata. A) male AMS R184779, Kyogle NSW (Jodi Rowley), B) male AMS R184704, Oxley Wild Rivers National Park, NSW (Jodi Rowley), C) male, no voucher, Guy Fawkes River National Park, NSW (Jodi Rowley), D) amplexing pair, no vouchers, Guy Fawkes River National Park, NSW (Jodi Rowley), E) male, no voucher, Guy Fawkes River National Park, NSW (Jodi Rowley), F) male, no voucher, Barrington NSW (Jodi Rowley), G) male, no voucher, Kookabookra NSW (Jodi Rowley), H) male AMS R184779, Kyogle, NSW (Jodi Rowley), I) male AMS R184704, Oxley Wild Rivers National Park, NSW (Jodi Rowley), J) male AMS R184705, Oxley Wild Rivers National Park, NSW (Jodi Rowley). 
Variation. Male SVL $28-42 \mathrm{~mm}$, females SVL $29-42 \mathrm{~mm}$. Summary of variation in morphometric variables for each sex is presented in Table 5.

Variation in colour is described from images taken in life (Fig. 10). Dorsal colouration varies from cream (e.g. Fig. 10E) to warm medium brown (e.g. Fig. 10A, B). All individuals have a distinct darker brown patch across head and down the back, narrowing in width over the axilla and then mid-dorsum, more diffuse posteriorly. A narrow, diffuse, medium-brown mid-dorsal line obvious in some individuals (e.g. Fig. 10A) and absent in others. Distinctly darker brown dorsolateral line running from eye, over tympanum, and diffusing above insertion of arm, becoming indistinct (versus continuing to groin as distinct line) in all individuals. Dark-brown stripe between eye and snout distinct in some individuals. Bright white patch on upper lip between lower margin of eye and insertion of the arm present in all individuals. Dorsal surface of limbs brown, finger tips often paler brown; toe tips pale brown, cream or pale yellow (e.g. Fig. 10F). Yellowish wash and/or paler cream patches in the groin region in some individuals, but both absent in most individuals examined. Back of thighs transparent pinkish orange with opaque, creamy yellow flecks; belly white; vocal sac in males black or very dark yellowish black when deflated and yellowish brown when inflated (Fig. 10). Iris copper-brown.

Advertisement call. Call descriptions are based on the calls of nine individuals (Table 6, Figs. 6, 8). The advertisement call of $L$. dentata comprises a single, highly-pulsed note. Individuals had a mean call duration of $0.84-1.33 \mathrm{~s}$ and an average of 44-53 uniformly spaced pulses repeated at a mean rate of 37-57 pulses/s. Calls were amplitude modulated, increasing rapidly to a peak at approximately $10 \%$ of the call duration. The mean dominant frequency was $2.9-4.0 \mathrm{kHz}$.

Comparison with other species. The distribution of $L$. dentata potentially overlaps with that of $L$. rubella in the north and abuts that of $L$. balatus sp. nov. in the north and $L$. quiritatus sp. nov. in the south. It is allopatric with the other five members of the L. rubella species group (L. electrica in north-western Queensland, L. congenita and L. pygmaea in New Guinea and L. capitula on Tanimbar Islands, Indonesia). Litoria dentata can be morphologically distinguished from L. rubella by the presence of continuous, irregularly edged, dark brown dorsal band and less robust body (versus head much narrower than body in L. rubella). It can be distinguished from L. electrica by the presence of continuous, irregularly edged, dark brown dorsal band (versus two dark chocolate-coloured bars across the dorsum). It can be distinguished from the New Guinean species L. congenita and L. pygmaea by absence of light spots on dark dorsal background (versus large and conspicuous usually present in L. pygmaea; smaller and more variable usually present in $L$. congenita). It can be distinguished from $L$. capitula by the absence of distinctive pale markings above the groin, vent and along lower leg that are present in L. capitula.

Litoria dentata can be distinguished from L. quiritatus sp. nov. by males having a vocal sac that is black or very dark yellowish black when deflated and yellowish brown when inflated (versus yellow when deflated and inflated). It can be distinguished from L. balatus sp. nov. by males having a vocal sac that is black or very dark yellowish black when deflated and yellowish brown when inflated (versus black when deflated and inflated), having a dorsolateral line diffusing above insertion of arm (versus continuing to groin) and having a less slender habitus (Fig. 5). From a genetic perspective, apomorphic nucleotide states at 28 sites in the mitochondrial ND4 gene reliably diagnose $L$. dentata from L. balatus sp. nov. and L. quiritatus sp. nov. (Table 7).

Distribution. Found along the coast of northeastern NSW from Taree (location 9) and Upper Pappinbarra (location 12) to at least as far north as the NSW-Queensland border (Border Ranges National Park, Fig. 7). Determination of the species identity of populations along the border (e.g. Springbrook, Numinbah Valley, Girraween National Park, Durikai State Forest) will require collection of nuclear gene data. It is possible that $L$. dentata extends further north along the Great Dividing Range as there are records of this species complex from upland mesic forests at Main Range, e.g. Cunningham's Gap and Goomburra (HBH unpublished data). Litoria dentata has also been introduced into Lord Howe Island (Plenderleith et al. 2015; Fig 2.). The known elevation range of the species is from sea level to $\sim 1250 \mathrm{~m}$.

Ecology. Litoria dentata calls from the ground or emergent vegetation associated with permanent or ephemeral water courses and ponds in both natural and disturbed habitats. Published descriptions of oviposition, egg and larval morphology, development and behaviour for L. dentata sensu lato (Anstis 2008) are based on L. quiritatus sp. nov. and have not been documented for $L$. dentata. The species is relatively commonly recorded via FrogID ( $>1600$ records from 10 November 2017-30 June 2021), and is relatively commonly heard calling in disturbed areas, with $17 \%$ of FrogID records of the species documented as being in suburban or urban habitats and $43 \%$ of records in rural areas. Litoria dentata has been detected calling from August to March, with single recordings in April and June, and a peak calling period of October to April via the FrogID project. 
Conservation status. Litoria dentata is a relatively widespread frog species, with an estimated Extent of Occurrence of approximately $94,000 \mathrm{~km}^{2}$. There are no documented or suspected population declines, so the species is likely to meet the IUCN Red List criteria (IUCN 2012) for Least Concern.

TABLE 7. Twenty-eight apomorphic diagnostic nucleotide states (in bold) for L. balatus sp. nov., L. dentata and $L$. quiritatus sp. nov. in the ND4 alignment (618 bp) with site numbering referenced against Hyla annectans complete mitochondrial genome (GenBank accession KM271781) with numbering commencing from the start codon.

\begin{tabular}{|c|c|c|c|c|c|c|c|c|c|c|c|c|c|c|c|c|c|c|c|c|c|c|c|c|c|c|c|c|}
\hline & & & & & & & 1 & 1 & 1 & 1 & 1 & 1 & 1 & 1 & 1 & 1 & 1 & 1 & 1 & 1 & 1 & 1 & 1 & 1 & 1 & 1 & 1 & 1 \\
\hline & 7 & 7 & 7 & 7 & 8 & 9 & 0 & 0 & 0 & 0 & 0 & 1 & 1 & 1 & 1 & 1 & 1 & 1 & 1 & 1 & 2 & 2 & 2 & 2 & 2 & 2 & 2 & 3 \\
\hline & 4 & 4 & 5 & 7 & 5 & 4 & 2 & 3 & 7 & 7 & 8 & 1 & 3 & 5 & 5 & 5 & 7 & 7 & 7 & 8 & 3 & 3 & 3 & 4 & 4 & 5 & 7 & 3 \\
\hline Species & 2 & 5 & 6 & 8 & 2 & 5 & 6 & 0 & 7 & 8 & 9 & 9 & 7 & 0 & 2 & 5 & 4 & 7 & 9 & 8 & 0 & 6 & 9 & 2 & 8 & 8 & 3 & 8 \\
\hline $\begin{array}{l}\text { L. balatus } \\
\text { sp. nov. }\end{array}$ & $\mathrm{T}$ & $\mathrm{A}$ & A & $\mathrm{C}$ & $\mathrm{T}$ & A & $\mathrm{C}$ & $\mathrm{T}$ & A & $\mathrm{A}$ & A & $\mathrm{C}$ & $\mathrm{A}$ & $\mathrm{C}$ & A & $\mathrm{T}$ & $\mathrm{T}$ & G & $\mathrm{G}$ & $\mathrm{C}$ & $\mathrm{C}$ & A & $\mathrm{C}$ & $\mathrm{G}$ & $\mathrm{A}$ & $\mathrm{A}$ & $\mathrm{A}$ & $\mathrm{C}$ \\
\hline L. dentata & A & G & A & $\mathrm{T}$ & $\mathrm{T}$ & G & $\mathrm{C}$ & $\mathrm{T}$ & G & A & A & $\mathrm{T}$ & $\mathrm{T}$ & $\mathrm{C}$ & G & $\mathrm{T}$ & $\mathrm{T}$ & G & $\begin{array}{l}\mathrm{A} / \\
\mathrm{T}\end{array}$ & $\mathrm{C}$ & $\mathrm{T}$ & $\begin{array}{l}\mathrm{A} / \\
\mathrm{G}\end{array}$ & $\mathrm{T}$ & A & G & A & A & $\mathrm{T}$ \\
\hline $\begin{array}{l}L . \\
\text { quiritatus } \\
\text { sp. nov. }\end{array}$ & A & A & $\begin{array}{l}\text { G/ } \\
\mathbf{T}\end{array}$ & $\mathrm{T}$ & A & G & $\mathrm{T}$ & $\mathrm{C}$ & $\mathrm{T}$ & $\mathbf{T}$ & $\mathbf{T}$ & $\mathrm{T}$ & $\mathbf{A}$ & $\mathrm{C}$ & $\mathbf{A}$ & C & $\mathrm{C}$ & A & A & $\mathbf{T}$ & $\mathrm{T}$ & G & $\mathrm{T}$ & A & A & $\mathbf{T}$ & $\mathbf{T}$ & $\mathrm{T}$ \\
\hline$L$ electrica & A & A & A & $\mathrm{C}$ & A & G & $\mathrm{T}$ & $\mathrm{C}$ & $\mathrm{T}$ & A & A & $\mathrm{T}$ & $\mathrm{T}$ & $\mathrm{C}$ & G & $\mathrm{T}$ & $\mathrm{C}$ & A & A & $\mathrm{C}$ & $\mathrm{T}$ & $\mathrm{T}$ & $\mathrm{T}$ & A & A & A & A & A \\
\hline$L$ rubella & A & A & A & $\mathrm{C}$ & A & $\mathrm{G}$ & $\mathrm{T}$ & $\mathrm{C}$ & $\mathrm{T}$ & A & A & $\mathrm{T}$ & $\mathrm{T}$ & $\mathrm{C}$ & G & $\mathrm{T}$ & $\mathrm{C}$ & A & A & $\mathrm{C}$ & $\mathrm{T}$ & $\mathrm{T}$ & $\mathrm{T}$ & A & A & A & A & A \\
\hline
\end{tabular}

\section{Litoria balatus sp. nov.}

Slender Bleating Tree Frog

Figs 11,12

Holotype. QM J91105. An adult male collected from a small drainage in the northeastern corner of Anstead Bushland Reserve, near the junction of Mt Crosby and Hawkesbury Roads, Anstead, south-eastern Queensland (-27.5406, 152.8614) by Harry B. Hines on 2 February 2010.

Material examined. See Supplementary Table S1 for details of all material examined.

Dimensions of holotype (mm). SVL 36.3; HL 10.2; HW 10.6; IND 2.4; EN 3.4; ED 3.5; IOD 6.4; TD 2.1; FLL 6.7; Fin3L 8.9; TL 14.8; Toe4L 13.7.

Diagnosis. Litoria balatus sp. nov. is distinguished from all species in the Litoria rubella group by a combination of (1) adult body size 26-44 mm in males and 33-43 mm in females, (2) relatively slender build, (3) the presence of a single, continuous, irregularly edged, dark brown dorsal band, (4) the absence of light spots on the dorsum, (5) lack of a well-defined pale mid-dorsal stripe, (6) absence of distinctive pale markings above the groin, vent and along lower leg, (7) presence of a distinct dorsolateral line continuing to groin, and (8) adult males having a vocal sac that is black.

Description of holotype. Habitus slender; head widest at eyes, slightly wider than long (HW/HL 1.04); snout rounded in lateral and dorsal profiles; nostrils prominent in dorsal profile; vomerine teeth in single row running laterally anteriorly to choanae. Tympanum circular and clearly visible, about half the diameter of the eye (TD/ED $0.61)$.

Fingers and toes with prominent terminal discs; fingers with basal webbing, toes half webbed. Relative lengths of fingers $3>4>2>1$; of toes $4>5=3>2>1$. Sub-articular tubercles present under fingers and toes but not prominent; inner metatarsal tubercles present and prominent, approximately one third the length of first toe. Nuptial pad oval, restricted to dorsal surface of proximal half of first finger, comprised of small granules. Legs short (TL/SVL 0.41).

In life, all dorsal surfaces dark brown, contrasting strongly with pale ventral surfaces of body and limbs (Fig. 11). Continuous, irregularly edged, broad dark brown dorsal band from the snout to the vent, extending laterally to the dorsolateral margin. Flanks light brown. Dorsum weakly granular, becoming more granular laterally, on venter and on thighs. Upper surfaces of legs, arms and distal lower surfaces of legs and arms smooth. A dark stripe extends from snout, through eye, onto tympanum continues laterally above arm and then along lateral ventral margin of body to groin. White bar directly under eye and tympanum, immediately posterior to the tympanum. Ventral surface immaculate light cream. Single vocal sac and chin darkly pigmented, brownish-black, lower lip cream (Fig. 11D). 

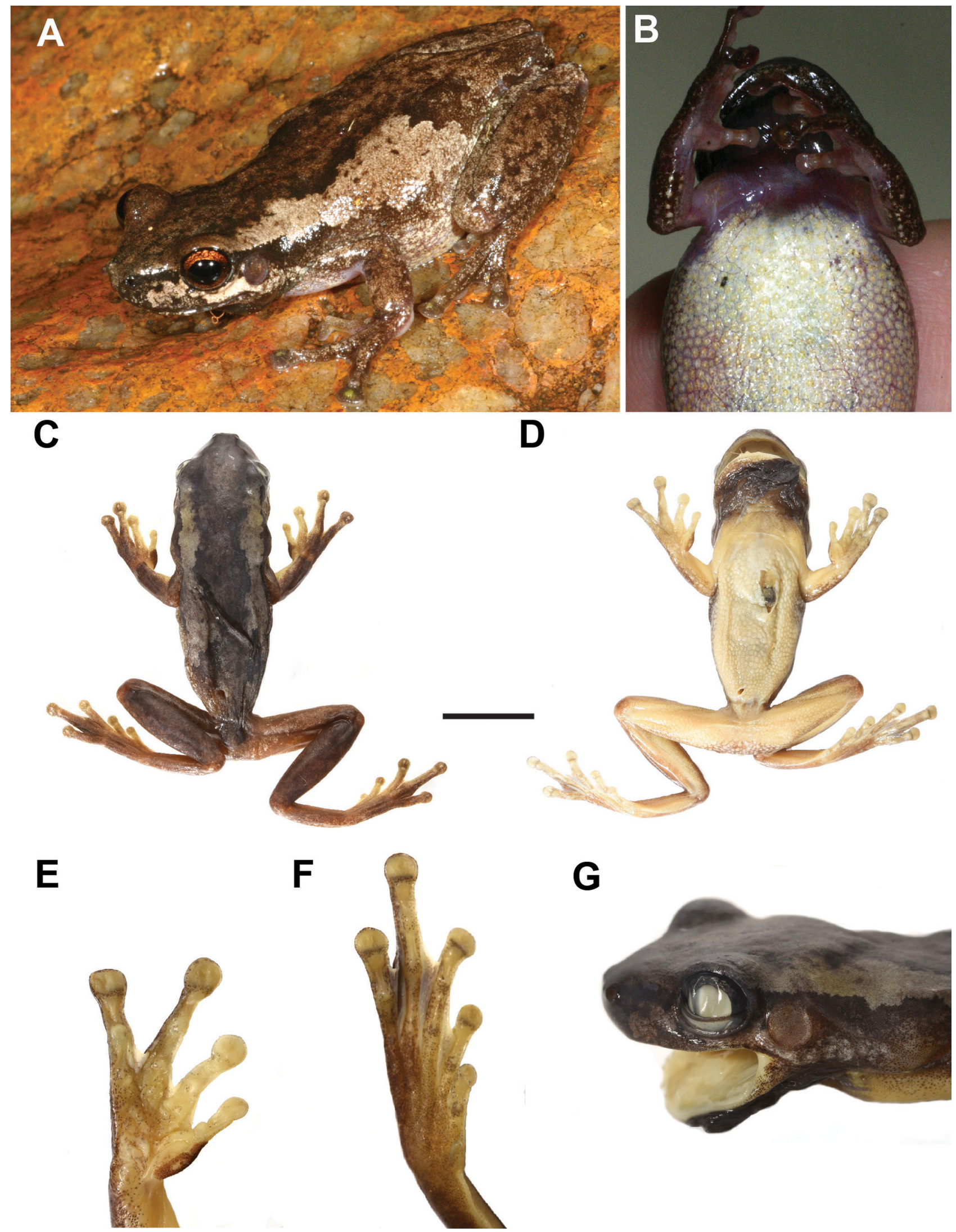

FIGURE 11. Holotype of Litoria balatus sp. nov. QM J91105. A) in life, B) view of throat in life, C) dorsal view in preservative D) ventral view in preservative, E) palmar view of hand in preservative, F) plantar view of foot in preservative, G) lateral view of head in preservative. Scale bar $=1 \mathrm{~cm}$. Images in life Harry B. Hines and in preservative Jodi Rowley. 

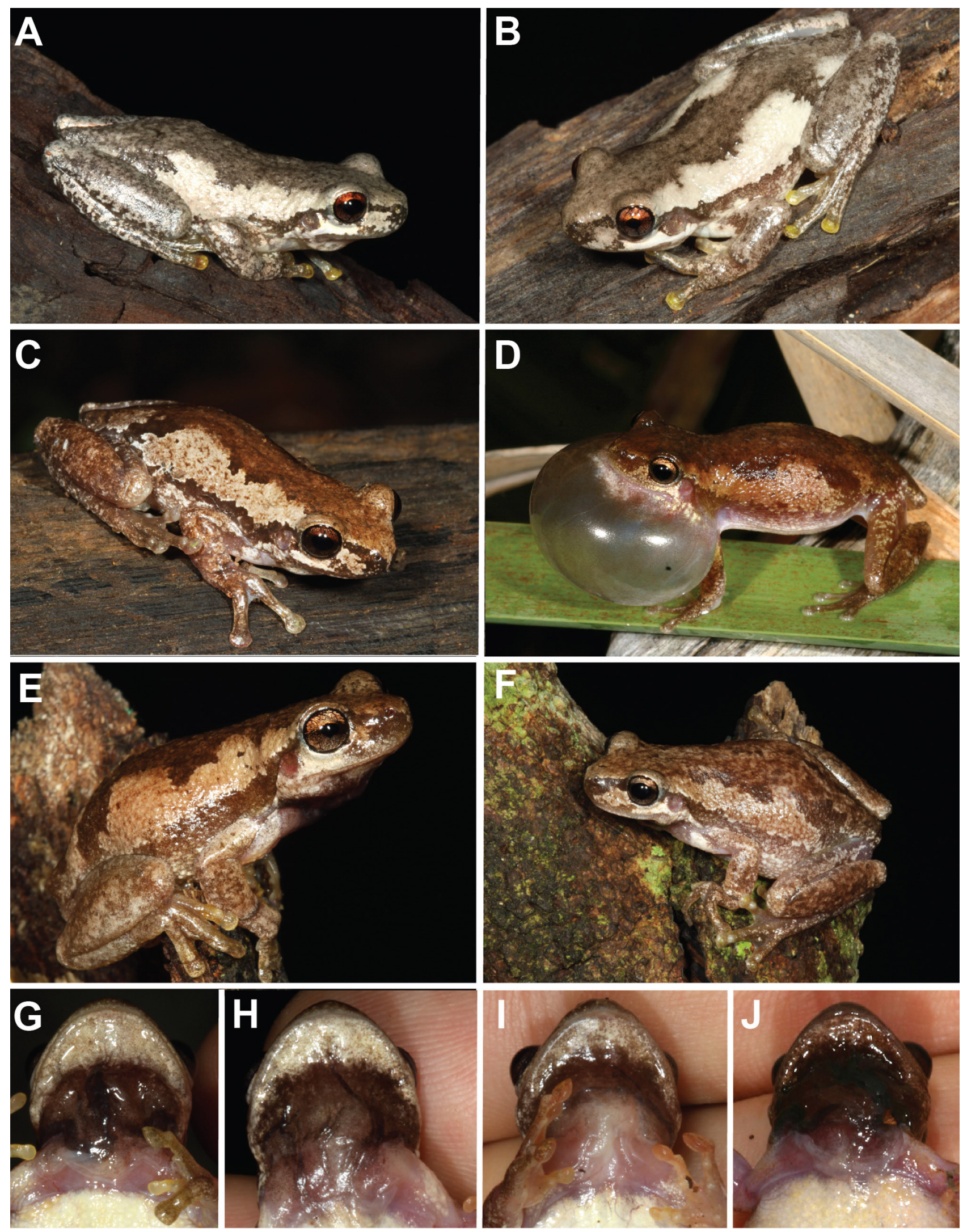

FIGURE 12. Images in life of Litoria balatus sp. nov. A) QM J95155, B) QM J95156, Mount Victoria, Bunya Mountains Road, adjoining Bunya Mountains National Park, Qld, C) QM J93232, Ocean View, Qld, D) QM J86660, Karawatha Forest Park, Qld, E) QM J97210, Samsonvale, Qld, F) QM J96340, Maroon, Qld, G) QM J97210, Samsonvale, Qld, H) QM J96340, Maroon, Qld, I) QM J96341, Barney View, Qld, J) QM J86661, Karawatha, Qld. All images by Harry B. Hines. 
Variation. Male SVL $26-44 \mathrm{~mm}$, female SVL $33-43 \mathrm{~mm}$. Summary of variation in morphometric variables for each sex is presented in Table 5 .

Variation in colour in life is described from images (Fig. 12). Dorsal colouration varies from cream (e.g. Fig. 12A) to a warm medium brown (e.g. Fig. 12D), with a distinct darker brown or brownish-grey patch across head and down the back, narrowing in width over the axilla and then also on the mid-dorsum. Some individuals mottled (e.g. Fig. 12F). Paler mid-dorsal line absent. Distinctly darker dorsolateral line running from snout, through eye, over tympanum, and down side of body to groin varies from medium- to dark- brown Bright white patch on upper lip between lower margin of eye and insertion of the arm. Dorsal surface of limbs medium-brown; finger and toe tips vary from medium-brown to pale yellow (e.g. Fig. 12A, B). Back of thighs transparent pinkish-orange or yellow-orange with varying amounts of darker brown pigment and opaque, creamy yellow flecks (e.g. Fig. 5A-C). Belly white; vocal sac in males black when deflated and grey when inflated (Fig. 12G-J). Iris copper-brown (e.g. Fig. 12E, F) to reddish-copper (e.g. Fig. 12A).

Advertisement call. Call descriptions are based on the calls of eight individuals, including the holotype (Table 6, Figs. 6, 8). The advertisement calls of $L$. balatus sp. nov. comprises a single, highly-pulsed note. Individuals had a mean call duration of $0.63-1.12 \mathrm{~s}$ and an average of 45-77 uniformly spaced pulses repeated at a rate of 57-89 pulses/s. Calls were amplitude modulated, increasing either smoothly or rapidly to a peak at approximately $10-20 \%$ of the call duration, but with much variation. The dominant frequency was $3.4-4.3 \mathrm{kHz}$.

Comparison with other species. The distribution of L. balatus sp. nov. overlaps with L. rubella and may overlap with $L$. dentata in the Scenic Rim area of Queensland, but it is allopatric with the other six members of the L. rubella species group (L. quiritatus from southern NSW and eastern Victoria, L. electrica from north-western Queensland, L. congenita and L. pygmaea in New Guinea and L. capitula on Tanimbar Islands, Indonesia). It can be distinguished from $L$. rubella by the presence of a continuous, irregularly edged, dark brown dorsal band and a less robust body (i.e. head much narrower than body in L. rubella). In addition, the call of L. balatus $\mathbf{s p . ~ n o v . ~ i s ~}$ much higher pitched, of longer duration, with more pulses and a faster pulse repetition rate than that of $L$. rubella in south-eastern Queensland. Litoria balatus sp. nov. is widely sympatric with L. rubella, and with the two species often calling together these differences in advertisement call are readily apparent. Litoria balatus sp. nov. can be distinguished from L. electrica by the presence of a continuous, irregularly edged, dark brown dorsal band (versus two dark chocolate-coloured bars across the dorsum). It can be distinguished from the New Guinean species $L$. congenita and L. pygmaea by absence of light spots (versus large and conspicuous in L. pygmaea, smaller and more variable in $L$. congenita) on dark dorsal background. It can be distinguished from $L$. capitula by the absence of distinctive pale markings above the groin, vent and along lower leg that are present in L. capitula. L. balatus sp. nov. can be distinguished from $L$. dentata by males having a vocal sac that is black when deflated and inflated (versus black or very dark yellowish black when deflated and yellowish brown when inflated). It can be distinguished from L. quiritatus sp. nov. by males having a vocal sac that is black (versus yellow when deflated and inflated). It can be distinguished further from $L$. dentata and L. quiritatus sp. nov. by having a distinct dorsolateral line continuing to groin (versus diffusing above insertion of arm), and more slender build (Fig. 5). From a genetic perspective, apomorphic nucleotide states at 28 sites in the mitochondrial ND4 gene reliably diagnose L. balatus sp. nov. from L. dentata and L. quiritatus sp. nov. (Table 7).

Etymology. The specific epithet, balatus, is a masculine Latin $4^{\text {th }}$ declension noun, meaning "a bleating", used as a noun in apposition to the genus name.

Distribution. Litoria balatus sp. nov. is known currently from south-eastern Queensland from the Maryborough district in the north (Biggenden, QM J24056) to the foothills of the scenic rim (Barney View, QM J96341), west to the Bunya Mountains. There are records of L. dentata sensu lato further north (e.g. Atlas of Living Australia), but there are no specimens or photographs available to verify these. The northernmost record of $L$. balatus sp. nov. in the FrogID project to date is in Maryborough. We are aware of a number of cases of Litoria rubella being misidentified as L. dentata sensu lato. Juvenile Litoria rubella, especially in the Gladstone region, often have extensive dark markings on the dorsum, causing confusion. We sequenced one such juvenile L. rubella (QM J90515, ABTC 127683) from the Mount Larcom area, near Gladstone to confirm its identity (Fig. 2). Further surveys are required to ascertain the northern distributional limits of $L$. balatus sp. nov.

Litoria balatus sp. nov. has a patchy distribution and is apparently absent from wallum habitats and from larger expanses of rainforest (Fig. 1). It occurs from near sea level, e.g., around the Woongoolba area (QM J92771, ABTC $127802)$ to $\sim 600 \mathrm{~m}$ in the Bunya Mountains and Conondale Range. 
The ranges of Litoria balatus sp. nov. and L. dentata are in close proximity in the Scenic Rim on the NSWQueensland border. We found individuals with discordant mtDNA ancestry and phenotypes (body habitus) in this area (Fig. 7) for which we currently do not have nuclear genotype data to establish their species identity. The Scenic Rim is characterised by mountainous terrain rising steeply above the coast and floodplains. Consequently, rainfall, temperature and vegetation vary markedly over very short distances. These patterns strongly influence the distribution of many vertebrate species in this region, and it is recognised as an area of overlap between northern and southern faunal groups (Bryant \& Krosch 2016). Within Anura, for example, Pseudophryne coriacea occurs in the Scenic Rim area but is replaced to the north by P. raveni (Ingram \& Corben 1994). The Scenic Rim area is also the northern limit for the anuran genera Philoria and Australian Lechriodus (the latter also has species in New Guinea). Additional nuclear genotyping is required in the Scenic Rim area to better understand the distribution of the two Litoria species and in particular to assign species identity to records of this species complex from the SpringbrookNuminbah Valley, the O'Reilly's Plateau-Christmas Creek-Canungra area or from the Great Dividing Range from Girraween National Park, through Main Range National Park to Toowoomba, and from Durikai State Forest.

Ecology. Most publications concerning L. dentata sensu lato do not include observations or data from Queensland, hence existing information on L. balatus sp. nov. is scant. Delvinquier (1986) recorded the protozoan parasite Myxidium immersum from Samford, Queensland, in a host now attributable to L. balatus sp. nov. Murray et al. (2007) list a single histological specimen of $L$. dentata from Belli Creek SEQ that was negative for the fungal pathogen Batrachochytrium dendrobatidis: this record is now attributable to L. balatus sp. nov. The following information is from field observations (H. B. Hines \& E. Meyer unpubl. data) or from FrogID as acknowledged.

Litoria balatus sp. nov. is a species of open forests, woodlands and occasionally rainforest. It appears to be largely absent from the coastal wallum communities and has not been recorded from any of the large sand islands of south-east Queensland (Hines \& Meyer 2011). Data from FrogID ( $>630$ records from 10 November 2017-30 June 2021) show that this species frequently calls from disturbed areas, with $14 \%$ of records in urban habitats and $60 \%$ in rural areas.

The species has been recorded calling from September to March via the FrogID project. Males call occasionally from treetops and buildings during the day, particularly in hot and humid weather but persistent calling and congregations of calling males typically occur at night following heavy or prolonged rainfall during the warmer months. Amplexus has been observed in all months from October to March. Breeding occurs in shallow ephemeral drainage lines or wetlands with emergent vegetation, with small dams also regularly used. Oviposition, eggs and larval morphology, development and behaviour have not been documented.

Conservation status. Litoria balatus sp. nov. is the most restricted of the three species, with an estimated Extent of Occurrence of $73,000 \mathrm{~km}^{2}$. There were no ill or dead specimens of L. balatus sp. nov. in the study of Berger et al. (2004) that examined a large number of diseased wild frogs from south-eastern Queensland. The fungal pathogen Batrachochytrium dendrobatidis has not been recorded in L. balatus sp. nov. (Murray et al. 2007) although screening is very limited $(\mathrm{n}=1)$. There are no documented or suspected population declines. Given the large Extent of Occurrence, persistence in disturbed areas and a lack of evidence of population declines, the species likely meets IUCN Red List criteria (IUCN 2012) for Least Concern.

\section{Litoria quiritatus sp. nov.}

Screaming Tree Frog

Figs 13, 14

Holotype. AMS R185759. An adult male collected from Coalcliff, New South Wales $(-34.247,150.975)$ by Richard Major on 6 October 2017.

Material examined. See Supplementary Table S1 for details of all material examined.

Dimensions of holotype (mm). SVL 39.8; HL 10.8; HW 11.6; IND 2.5; EN 3.3; ED 3.4; IOD 7.7; TD 1.4; FLL 6.9; Fin3L 11.9; TL 17.1; Toe4L 16.2.

Diagnosis. Litoria quiritatus sp. nov. is distinguished from all species in the Litoria rubella group by a combination of (1) adult body size 36-43 $\mathrm{mm}$ in males and 34-46 mm in females, (2) relatively robust build, (3) the presence of a single, continuous, irregularly edged, dark brown dorsal band, (4) the absence of light spots on the dorsum, (5) lack of a well-defined pale mid-dorsal stripe, (6) absence of distinctive pale markings above the groin, 
vent and along lower leg, (7) a dorsolateral line diffusing above insertion of the arm, and (8) adult males having a vocal sac that is yellow when deflated and when inflated.

Description of holotype. Habitus relatively robust; head widest at eyes, slightly wider than long (HW/HL 1.08); snout bluntly rounded in profile and obtusely pointed in dorsal view; nostrils prominent in dorsal profile; vomerine teeth in single row running laterally anteriorly to choanae; tympanum circular and clearly visible and twothirds the diameter of the eye (TD/ED 0.67).

A

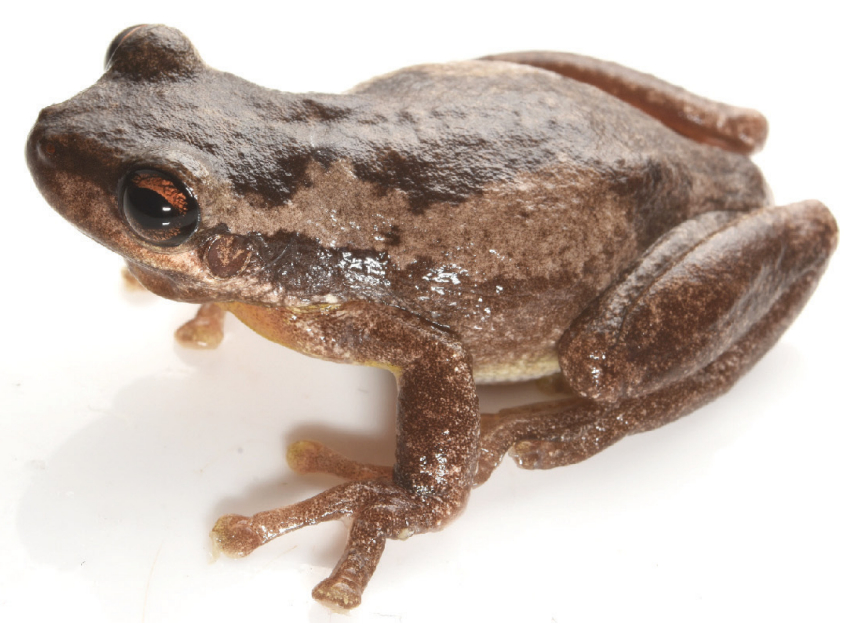

B

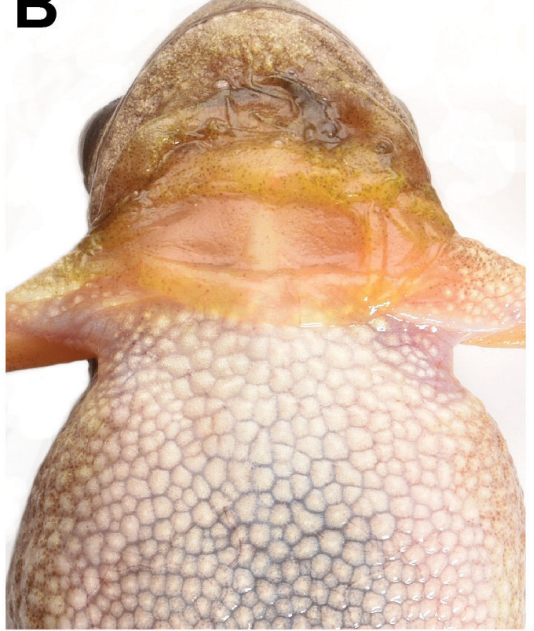

C

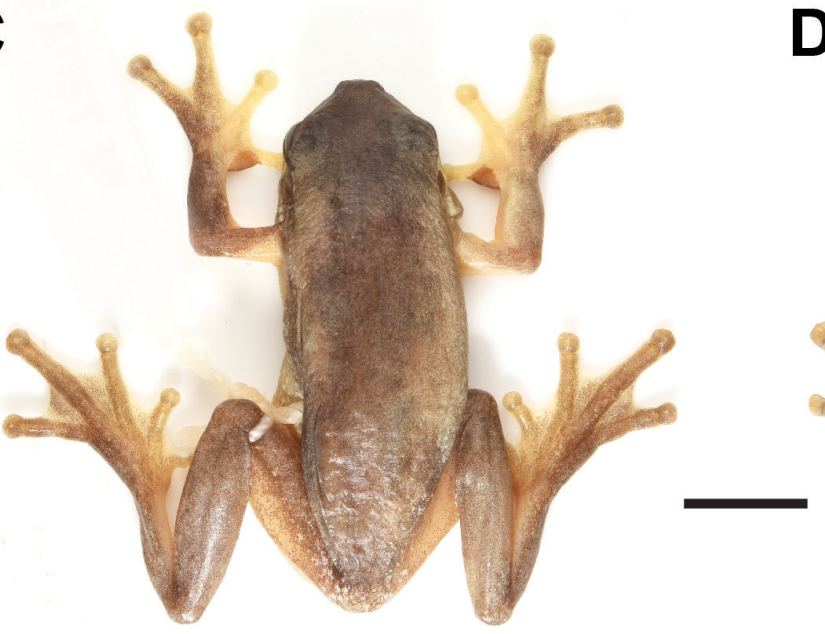

$\mathbf{E}$

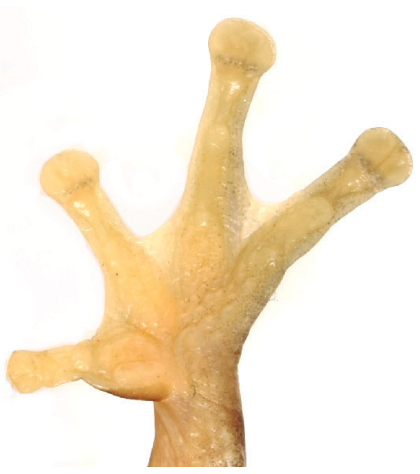

$\mathbf{F}$

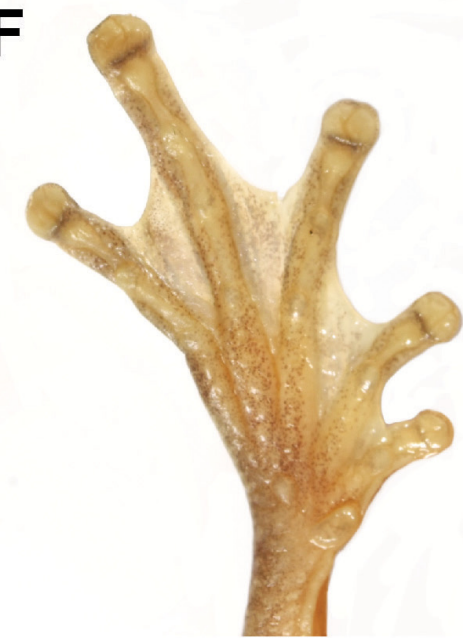

D
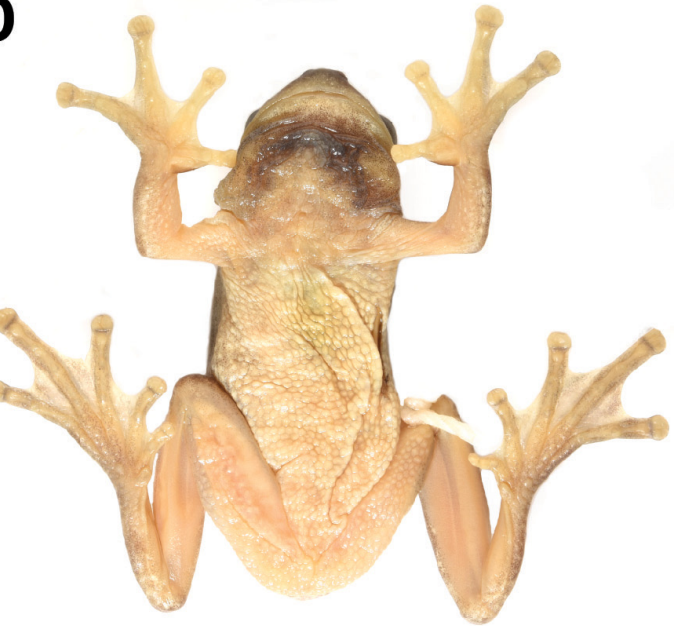

G

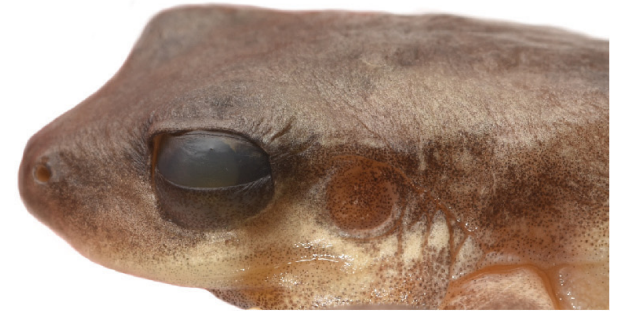

FIGURE 13. Holotype of Litoria quiritatus sp. nov. AMS R185759 A) dorsolateral, B) ventral view of throat and chest, C) dorsal view, D) ventral view, E) palmar view of hand, F) plantar view of foot, G) lateral view of head. Scale bar $=1 \mathrm{~cm}$. 

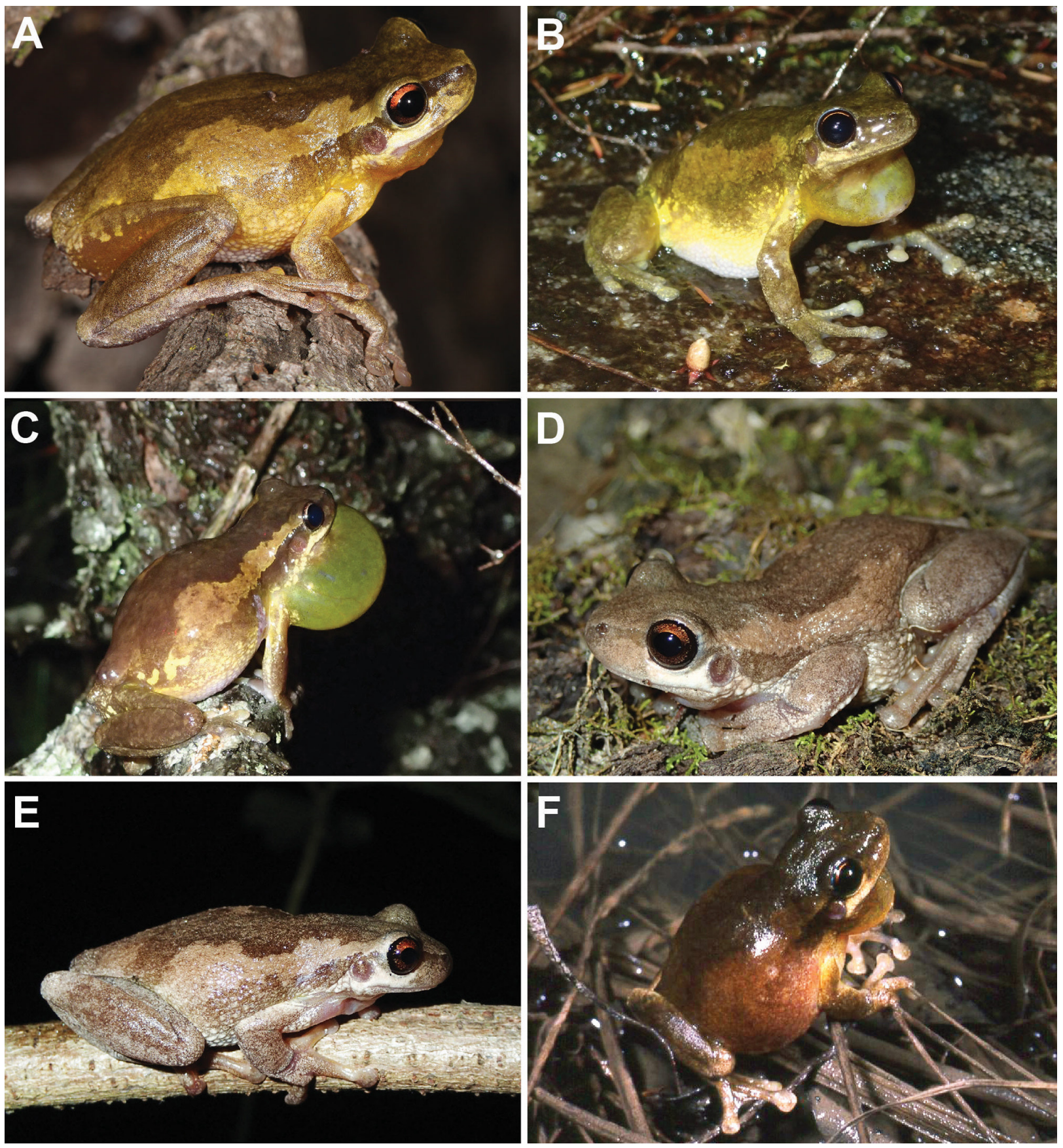

FIGURE 14. Images in life of Litoria quiritatus sp. nov. A) male, no voucher, Blacktown, NSW (Stephen Mahony), B) male, no voucher, Darkes Forest, NSW (Jodi Rowley), C) male, no voucher, Darkes Forest NSW (Jodi Rowley), D) male, no voucher, Barrington, NSW (Jodi Rowley), E) male, no voucher, Barrington, NSW (Jodi Rowley), F) male, Ourimbah, no voucher, NSW (Steve Donnellan).

Fingers and toes with prominent terminal discs; fingers with basal webbing; toes half webbed. Relative lengths of fingers $3>4>2>1$; of toes $4>5=3>2>1$. Sub-articular tubercles present under fingers and toes but not prominent. Inner metatarsal tubercles present and prominent, approximately one third the length of first toe. Nuptial pad oval, restricted to dorsal surface of proximal half of first finger, comprised of small granules. Legs short (TL/SVL 0.43).

All dorsal surfaces dark brown, contrasting strongly with ventral surface of body and limbs (Fig. 13). Continuous, irregularly edged, dark-brown dorsal band from snout to vent, extending laterally to the dorsolateral margin. Flanks light brown. Dorsum very weakly granular, upper surfaces of legs, arms and distal lower surfaces of limbs smooth. Broad irregular, lighter brown bands on each side, from back of eye. A dark brown stripe from snout, through eye, onto tympanum and continuing laterally above arm and along lateral ventral margin of body, diffusing above 
insertion of the arm. Groin with yellowish orange wash and distinct white patches. White bar directly under eye and tympanum and immediately posterior to tympanum. Ventral surface immaculate light cream. Single vocal sac and chin dark brownish-grey and yellow; lower lip cream.

Variation. Male SVL 36-43 mm; female SVL 34-46 mm. Summary of variation in morphometric variables for each sex is presented in Table 5 .

Variation in colour is described from images taken in life (Fig. 14). Dorsal colouration varies from cream (e.g. Fig. 14E) to warm medium-brown (e.g. Fig. 14F), with a distinct darker brown patch across the head and down the back, narrowing in width over the axilla and then mid-dorsum, more diffuse posteriorly. Very narrow, diffuse paler brown mid-dorsal line present in some individuals (e.g. Fig. 14D). Darker brown dorsolateral line running from snout, through eye, over tympanum, and down the side of the body, diffusing above insertion of the arm, more diffuse posteriorly; distinctness of this line varies. Bright white patch on upper lip between lower margin of eye and insertion of arm. Dorsal surface of limbs brown, finger and toe tips may be slightly paler brown (e.g. Fig. 14F). White or pale yellowish patches in the groin (e.g. Fig. 14C) almost always present but vary in size and number. Back of thighs transparent pinkish-orange or yellowish-orange with varying amounts of darker brown pigment and opaque, creamy yellow flecks. Belly white; vocal sac in males dark yellow when deflated and pale yellow when inflated (Fig. 14B, C, F). Iris copper-brown (e.g. Fig. 14D) to reddish-copper (e.g. Fig. 13A). During the breeding season males become yellowish (e.g. Fig. 14A, B).

Advertisement call. Call descriptions are based on the calls of 16 individuals, including the holotype (Table 6, Figs. 6, 8). The advertisement call of L. quiritatus sp. nov. comprises a single, highly-pulsed note. Individuals had a mean call duration of $0.70-1.31 \mathrm{~s}$ and an average of 24-51 uniformly spaced pulses repeated at a rate of 30-53 pulses/s. Calls were amplitude modulated, and highly variable in the timing of their peak amplitude with respect to call duration. The dominant frequency was $3.1-4.1 \mathrm{kHz}$.

Comparison with other species. The distribution of $L$. quiritatus sp. nov. is parapatric with $L$. dentata but is allopatric with the other members of the L. rubella species group (L. balatus sp. nov. in south-eastern Queensland, L. electrica in north-western Queensland, L. congenita and L. pygmaea in New Guinea and L. capitula on the Tanimbar Islands, Indonesia). Litoria quiritatus sp. nov. can be distinguished from L. rubella by the presence of continuous, irregularly edged, dark brown dorsal band (versus absence) and less robust body (versus more robust). It can be distinguished from L. electrica by the presence of continuous, irregularly edged, dark brown dorsal band (versus two dark chocolate-coloured bars across the dorsum). It can be distinguished from the New Guinean species L. congenita and L. pygmaea by absence of light spots (usually large and conspicuous spots in L. pygmaea, smaller and more variable in L. congenita) on dark dorsal background. It can be distinguished from L. capitula by the absence of distinctive pale markings above the groin, vent and along lower leg that are present in L. capitula.

Litoria quiritatus sp. nov. can be distinguished from $L$. dentata by males having a vocal sac that is yellow when deflated and inflated (versus a vocal sac that is black or very dark yellowish black when deflated and yellowish brown when inflated). It can be distinguished from L. balatus sp. nov. by males having a vocal sac that is yellow when deflated and inflated (versus males having a vocal sac that is black) and having a robust build (versus slender build) (Fig. 5). From a genetic perspective, apomorphic nucleotide states at 28 sites in the mitochondrial ND4 gene reliably diagnose L. quiritatus $\mathbf{s p . ~ n o v . ~ f r o m ~ L . ~ b a l a t u s ~ s p . ~ n o v . ~ a n d ~ L . ~ d e n t a t a ~ ( T a b l e ~ 7 ) . ~}$

Etymology. The specific epithet, quiritatus, is a masculine Latin $4^{\text {th }}$ declension noun based on the verb quirito, meaning a shriek or scream, used as a noun in apposition to the genus name.

Distribution. In the south from the Genoa River, $10 \mathrm{~km} \mathrm{NW}$ Mallacoota, Victoria along the coast and eastern fall of the Great Dividing Range north to Mernot State Forest, NSW. The ranges of L. dentata and L. quiritatus sp. nov. approach to within $60 \mathrm{~km}$ of each other between Taree and Woko National Park respectively. The known elevation range of the species is from sea level to $\sim 1100 \mathrm{~m}$ on the Newnes Plateau, Blue Mountains.

Ecology. Litoria quiritatus sp. nov. calls from the ground or emergent vegetation associated with permanent or ephemeral water courses and ponds in both natural and disturbed habitats. Anstis (2018) described oviposition, egg and larval morphology, and development (as L. dentata) from Nowra, Darkes Forest, Watagan Mountains and the Blue Mountains. The species is the $24^{\text {th }}$ most commonly recorded species in the FrogID database ( $>3400$ records from 10 November 2017-30 June 2021) and appears relatively tolerant of disturbed areas, with $42 \%$ of records documented as being in suburban or urban habitats and $37 \%$ in rural areas. L. quiritatus sp. nov. has been detected via the FrogID project calling from August to May, with peak calling activity from September to February.

Conservation status. L. quiritatus sp. nov. is a relatively widespread frog species, with an estimated Extent of 
Occurrence of $145,000 \mathrm{~km}^{2}$. There are no documented or suspected population declines, so the species likely meets IUCN Red List criteria (IUCN 2012) for Least Concern.

\section{Acknowledgements}

We thank the Australian Biological Resources Study (grant number 205-54) for financial support, A. Borsboom, H. Cogger, G. Hoye, E. Meyer, M. Mathieson, D. Milledge, J. Rowland, M. Sanders and D. Stewart for supplying specimens, photos, calls or information, C. Kovach, R. Palmer, C. Beatson, R. Sadlier and A. Amey for access to vouchers and tissues, Wolfgang Böhme and Philipp Wagner (ZFMK) for supplying information and photographs of types, Alexis Tindall for assistance with photography; DArT P/L Canberra for carrying out the genotyping Service; and the FrogID project, particularly the thousands of citizen scientists across Australia who have volunteered their time to record frogs. Two anonymous reviewers provided detailed feedback that greatly improved the manuscript.

\section{References}

Alexander, D.H., Novembre, J. \& Lange, K. (2009) Fast model-based estimation of ancestry in unrelated individuals. Genome Research, 19, 1655-1664. https://doi.org/10.1101/gr.094052.109

Anderson, E.C. \& Thompson, E.A. (2002) A model-based method for identifying species hybrids using multilocus genetic data. Genetics, 160, 1217-1229. https://doi.org/10.1093/genetics/160.3.1217

Anstis, M. (2018) Tadpoles and frogs of Australia. New Holland Publishers, Sydney, 850 pp.

Anstis, M., Price, L.C., Roberts, J.D., Catalano, S., Doughty, P., Hines, H.B. \& Donnellan, S.C. (2016) Revision of the Australian water holding frog (Cyclorana platycephala, Anura: Hylidae), with a description of a new species and subspecies. Zootaxa, 4126 (4), 451-479. https://doi.org/10.11646/zootaxa.4126.4.1

Berger, L., Speare, R., Hines, H.B., Marantelli, G., Hyatt, A.D., McDonald, K.R., Skerratt, L.F., Olsen, V., Clarke, J.M., Gillespie, G., Mahony, M., Sheppard, N., Williams, C. \& Tyler, M.J. (2004) Effect of season and temperature on mortality in amphibians due to chytridiomycosis. Australian Veterinary Journal, 82, 434-439. https://doi.org/10.1111/j.1751-0813.2004.tb11137.x

Bouckaert, R., Heled, J., Kuhnert, D., Vaughan, T., Wu, C.-H., Xie, D., Suchard, M.A., Rambaut, A. \& Drummond, A.J. (2014) BEAST 2: A Software Platform for Bayesian Evolutionary Analysis. PLoS Computational Biology, 10, e1003537. https://doi.org/10.1371/journal.pcbi.1003537

Bryant, L.M. \& Krosch, M.N. (2016) Lines in the land: a review of evidence for eastern Australia's major biogeographical barriers to closed forest taxa. Biological Journal of the Linnean Society, 119, 238-264. https://doi.org/10.1111/bij.12821

Bryant, D., Bouckaert, R., Felsenstein, J., Rosenberg, N.A. \& RoyChoudhury, A. (2012) Inferring species trees directly from biallelic genetic markers: bypassing gene trees in a full coalescent analysis. Molecular Biology and Evolution, 29, 19171932. https://doi.org/10.1093/molbev/mss086

Byrne, M., Steane, D.A., Joseph, L., Yeates, D.K., Jordan, G.J., Crayn, D., Aplin, K., Cantrill, D.J., Cook, L.G., Crisp, M.D., Keogh, J.S., Melville, J., Moritz, C., Porch, N., Sniderman, J.M.K., Sunnucks, P. \& Weston, P.H. (2011) Decline of a biome: evolution, contraction, fragmentation, extinction and invasion of the Australian mesic zone biota. Journal of Biogeography, $38,1635-1656$. https://doi.org/10.1111/j.1365-2699.2011.02535.x

Chambers, E.A. \& Hillis, D.M. (2020) The multispecies coalescent over-splits species in the case of geographically widespread taxa. Systematic Biology, 69, 184-193. https://doi.org/10.1093/sysbio/syz042

Chapple, D.G., Hoskin, C.J., Chapple, S.N.J. \& Thompson, M.B. (2011a) Phylogeographic divergence in the widespread delicate skink (Lampropholis delicata) corresponds to dry habitat barriers in eastern Australia. BMC Evolutionary Biology, 11, 191. https://doi.org/10.1186/1471-2148-11-191

Chapple, D.G., Chapple, S.N.J. \& Thompson, M.B. (2011b) Biogeographic barriers in south-eastern Australia drive phylogeographic divergence in the garden skink, Lampropholis guichenoti. Journal of Biogeography, 38, 1761-1775. https://doi.org/10.1111/j.1365-2699.2011.02531.x

Chifman, J. \& Kubatko, L. (2014) Quartet inference from SNP data under the coalescent model. Bioinformatics, 30, $3317-$ 3324. 
https://doi.org/10.1093/bioinformatics/btu530

Couper, P.J., Sadlier, R.A., Shea, G.M. \& Worthington-Wilmer, J. (2008) A reassessment of Saltuarius swaini (Lacertilia: Diplodactylidae) in southeastern Queensland and New South Wales; two new taxa, phylogeny, biogeography and conservation. Records of the Australian Museum, 60, 87-118. https://doi.org/10.3853/j.0067-1975.60.2008.1492

Delvinquier, B.L.J. (1986) Myxidium immersum (Protozoa, Myxosporea) of the cane toad, Bufo marinus, in Australian Anura, with a synopsis of the genus in amphibians. Australian Journal of Zoology, 34, 843-853. https://doi.org/10.1071/ZO9860843

Donnellan, S.C., McGuigan, K., Knowles, R., Mahony, M. \& Moritz, C. (1999) Genetic evidence for species boundaries in frogs of the Litoria citropa species group (Anura: Hylidae). Australian Journal of Zoology, 47, 275-293. https://doi.org/10.1071/ZO99013

Ford, J. (1987) Minor isolates and minor geographical barriers in avian speciation in continental Australia. Emu, 87, 90-102. https://doi.org/10.1071/MU9870090

Frichot, E., Mathieu, F., Trouillon, T., Bouchard, G. \& Francois, O. (2014) Fast and efficient estimation of individual ancestry coefficients. Genetics, 196, 973-983. https://doi.org/10.1534/genetics.113.160572

Georges, A., Gruber, B., Pauly, G., White, D., Adams, M., Young, M., Kilian, A., Zhang, X., Shaffer, H. \& Unmack, P. (2018) Genome - wide SNP markers breathe new life into phylogeography and species delimitation for the problematic short necked turtles (Chelidae: Emydura) of eastern Australia. Molecular Ecology, 27, 5195-5213. https://doi.org/10.1111/mec.14925

Gruber, B., Unmack, P.J., Berry, O.F. \& Georges, A. (2018) dartr: An R package to facilitate analysis of SNP data generated from reduced representation genome sequencing. Molecular Ecology Resources, 18, 691-699. https://doi.org/10.1111/1755-0998.12745

Gillespie, G.R. \& Kum, K.C. (2011) The bleating tree frog Litoria dentata Keferstein (Anura: Hylidae): An addition to the frog fauna of Victoria. The Victorian Naturalist, 128, 256.

Hines, H.B. \& Meyer, E. (2011) The frog fauna of Bribie Island: an annotated list and comparison with other Queensland dune islands. Proceedings of the Royal Society of Queensland, 117, 261-274.

Hoang, D.T., Chernomor, O., von Haeseler, A., Minh, B.Q. \& Vinh, L.S. (2018) UFBoot2: Improving the ultrafast bootstrap approximation. Molecular Biology Evolution, 35, 518-522. https://doi.org/10.1093/molbev/msx281

Hoskin, C.J., Couper, P.J. \& Schneider, C.J. (2003) A new species of Phyllurus (Lacertilia: Gekkonidae) and a revised phylogeny and key for the Australian leaf-tailed geckos. Australian Journal of Zoology, 51, 153-164. https://doi.org/10.1071/ZO02072

Ingram, G.J. \& Corben, C.J. (1994) Two new species of broodfrog (Pseudophryne) from Queensland. Memoirs of the Queensland Museum, 37, 267-272.

IUCN (2012) IUCN Red List categories and criteria. Version 3.1. $2^{\text {nd }}$ Edition. International Union for Conservation of Nature (IUCN) Species Survival Commission, Gland and Cambridge, $32 \mathrm{pp}$.

James, C.H. \& Moritz, C. (2000) Intraspecific phylogeography in the sedge frog Litoria fallax (Hylidae) indicates pre-Pleistocene vicariance of an open forest species from eastern Australia. Molecular Ecology, 9, 349-358. https://doi.org/10.1046/j.1365-294x.2000.00885.x

Jombart, T. (2008) Adegenet: a R package for the multivariate analysis of genetic markers. Bioinformatics, 24, $1403-1405$. https://doi.org/10.1093/bioinformatics/btn129

Joseph, L., Moritz, C. \& Hugall, A. (1993) A mitochondrial DNA perspective on the historical biogeography of mid-eastern Queensland rainforest birds. Memoirs of the Queensland Museum, 34, 201-214.

Joseph, L. \& Moritz, C. (1994) Mitochondrial DNA phylogeography of birds in Eastern Australian rainforests: first fragments. Australian Journal of Zoology, 42, 385-403. https://doi.org/10.1071/ZO9940385

Kalyaanamoorthy, S., Minh, B.Q., Wong, T.K.F., von Haeseler, A. \& Jermiin, L.S. (2017) ModelFinder: fast model selection for accurate phylogenetic estimates. Nature Methods, 14, 587-589. https://doi.org/10.1038/nmeth.4285

Kass, R.E. \& Raftery, A.E. (1995) Bayes factors. Journal of the American Statistical Association, 90, 773-795. https://doi.org/10.1080/01621459.1995.10476572

Kearse, M., Moir, R., Wilson, A., Stones-Havas, S., Cheung, M., Sturrock, S., Buxton, S., Cooper, A., Markowitz, S., Duran, C., Thierer, T., Ashton, B., Meintjes, P. \& Drummond, A. (2012) Geneious Basic: An integrated and extendable desktop software platform for the organization and analysis of sequence data. Bioinformatics Applications Note, 28, $1647-1649$. https://doi.org/10.1093/bioinformatics/bts199

Keferstein, W. (1868) Über die Batrachier Australiens. Archiv für Naturgeschichte Berlin, 34, 253-290. https://doi.org/10.5962/bhl.part.20476

Kilian, A., Wenzl, P., Huttner, E., Carling, J., Xia, L., Blois, H., Caig, V., Heller-Uszynska, K., Jaccoud, D., Hopper, C., Aschenbrenner-Kilian, M., Evers, M., Peng, K., Cayla, C., Hok, P. \& Uszynski, G. (2012) Diversity arrays technology: A generic genome profiling technology on open platforms. Methods in Molecular Biology, 888, 67-89. 
https://doi.org/10.1007/978-1-61779-870-2_5

Knowles, R., Mahony, M., Armstrong, J. \& Donnellan, S.C. (2004) Systematics of sphagnum frogs of the genus Philoria (Anura: Myobatrachidae) in eastern Australia. Records of the Australian Museum, 56, 57-74. https://doi.org/10.3853/j.0067-1975.56.2004.1391

Köhler, J., Jansen, M., Rodriguez, A., Kok, P.J., Toledo, L.F., Emmrich, M., Glaw, F., Haddad, C.F., Roedel, M.O. and Vences, M. (2017) The use of bioacoustics in anuran taxonomy: theory, terminology, methods and recommendations for best practice. Zootaxa, 4251 (1), 1-124. https://doi.org/10.11646/zootaxa.4251.1.1

Kumar, S., Stecher, G. \& Tamura, K. (2016) MEGA7: Molecular Evolutionary Genetics Analysis version 7.0 for bigger datasets. Molecular Biology and Evolution 33, 1870-1874. https://doi.org/10.1093/molbev/msw054

Lanfear, R., Frandsen, P.B., Wright, A.M., Senfeld, T. \& Calcott, B. (2017) PartitionFinder 2: new methods for selecting partitioned models of evolution for molecular and morphological phylogenetic analyses. Molecular Biology and Evolution, 34, $772-773$. https://doi.org/10.1093/molbev/msw260

Leaché, A. D., Fujita, M. K., Minin, V.N. \& Bouckaert, R.R. (2014) Species delimitation using genome-wide SNP data. Systematic Biology, 63, 534-542. https://doi.org/10.1093/sysbio/syu018

Leaché, A.D., Banbury, B.L., Felsenstein, J., de Oca, A.N. \& Stamatakis A. (2015) Short tree, long tree, right tree, wrong tree: new acquisition bias corrections for inferring SNP phylogenies. Systematic Biology, 64, 1032-1047. https://doi.org/10.1093/sysbio/syv053

Luedeling, E. (2019) chillR: statistical methods for phenology analysis in temperate fruit trees. R package. Version 0.70 .21 . Available from: https://rdrr.io/cran/chillR/man/chillR-package.html (accessed 1 November 2021)

Mahony, M.J., Knowles, R., Foster, R. \& Donnellan, S.C. (2001) Systematics of the Litoria citropa (Anura: Hylidae) complex in northern New South Wales and southern Queensland, Australia, with the description of a new species. Records of the Australian Museum, 53, 37-48. https://doi.org/10.3853/j.0067-1975.53.2001.1322

Mahony, M.J., Moses, B., Mahony, S., Lemckert, F. \& Donnellan, S.C. (2020). A new species of frog in the Litoria ewingii species group (Anura: Pelodryadidae) from south-eastern Australia. Zootaxa, 4858 (2), 201-230. https://doi.org/10.11646/zootaxa.4858.2.3

McGuigan, K., McDonald, K., Parris, K. \& Moritz, C. (1998) Mitochondrial DNA diversity and historical biogeography of a wet forest-restricted frog (Litoria pearsoniana) from mid-east Australia. Molecular Ecology, 7, 175-186. https://doi.org/10.1046/j.1365-294x.1998.00329.x

Miller, M.A., Pfeiffer, W. \& Schwartz, T. (2010) Creating the CIPRES Science Gateway for inference of large phylogenetic trees. In: Proceedings of the Gateway Computing Environments Workshop (GCE), New Orleans, Louisiana, 14 November 2010, pp. 1-8. https://doi.org/10.1109/GCE.2010.5676129

Mitchell, B.A., Callaghan, C.T. \& Rowley, J.J.L. (2020) Continental-scale citizen science data reveal no changes in acoustic responses of a widespread treefrog to an urbanisation gradient. Journal of Urban Ecology, 6, 1-12. https://doi.org/10.1093/jue/juaa002

Moussalli, A., Hugall, A.F. \& Moritz, C. (2005) A mitochondrial phylogeny of the rainforest skink genus Saproscincus, Wells and Wellington (1984). Molecular Phylogenetics and Evolution, 34, 190-202. https://doi.org/10.1016/j.ympev.2004.08.022

Murray, K., Retallick, R., McDonald, K.R., Mendez, D., Aplin, K., Kirkpatrick, P., Berger, L., Hunter, D., Hines, H.B., Campbell, R., Pauza, M., Driessen, M., Speare, R., Richards, S.J., Mahony, M., Freeman, A., Phillott, A.D., Hero, J.-M., Kriger, K., Driscoll, D., Felton, A., Puschendorf, R. \& Skerratt, L.F. (2010) The distribution and host range of the pandemic disease chytridiomycosis in Australia, spanning surveys from 1956-2007. Ecology, 91,1557-1558. https://doi.org/10.1890/09-1608.1

O'Connor, D.O. \& Moritz, C. (2003) A molecular phylogeny of the Australian skink genera Eulamprus, Gnypetoscincus and Nangura. Australian Journal of Zoology, 51, 317-330. https://doi.org/10.1071/ZO02050

Plenderleith, T.L., Smith, K.L., Donnellan, S.C., Reina, R.D. \& Chapple, D.G. (2015) Human-assisted invasions of Pacific Islands by Litoria frogs: a case study of the bleating tree frog on Lord Howe Island. PLoS One, 10, e0126287. https://doi.org/10.1371/journal.pone.0126287

Raj, A., Stephens, M. \& Pritchard, J.K. (2014) fastSTRUCTURE: variational inference of population structure in large SNP data sets. Genetics, 197, 573-589. https://doi.org/10.1534/genetics.114.164350

Rambaut, A., Drummond, A.J., Xie, D., Baele, G. \& Suchard, M.A. (2018) Posterior summarisation in Bayesian phylogenetics using Tracer 1.7. Systematic Biology, 67, 901-904.

https://doi.org/10.1093/sysbio/syy032

Renner, S.S. (2016) Return to Linnaeus's focus on diagnosis, not description: the use of DNA characters in the formal naming 
of species. Systematic Biology, 65, 1085-1095.

https://doi.org/10.1093/sysbio/syw032

Ronquist, F., Teslenko, M., van der Mark, P., Ayres, D.L., Darling, A., Höhna, S., Larget, B., Liu, L., Suchard, M.A. \& Huelsenbeck, J.P. (2012) MRBAYES 3.2: efficient Bayesian phylogenetic inference and model selection across a large model space. Systematic Biology, 61, 539-542. https://doi.org/10.1093/sysbio/sys029

Rosauer, D., Laffan, S.W., Crisp, M.D., Donnellan, S.C. \& Cook, L.G. (2009) Phylogenetic endemism: a new approach for identifying geographical concentrations of evolutionary history. Molecular Ecology, 18 (19), 4061-4072. https://doi.org/10.1111/j.1365-294X.2009.04311.x

Rowley, J.J.L., Callaghan, C.T., Cutajar, T., Portway, C., Potter, K., Mahony, S., Trembath, D.F., Flemons, P. \& Woods, A. (2019) FrogID: citizen scientists provide validated biodiversity data on frogs of Australia. Herpetological Conservation and Biology, 14, 155-170.

Schäuble, C.S., Moritz, C. \& Slade, R.W. (2000) A molecular phylogeny for the frog genus Limnodynastes (Anura: Myobatrachidae). Molecular Phylogenetics and Evolution, 16, 379-391. https://doi.org/10.1006/mpev.2000.0803

Schäuble, C.S. \& Moritz, C. (2001) Comparative phylogeography of two open forest frogs from eastern Australia. Biological Journal of the Linnean Society, 74, 157-170. https://doi.org/10.1111/j.1095-8312.2001.tb01384.x

Sparks, A.H., Padgham, M., Parsonage, H. \& Pembleton, K. (2017) "bomrang: fetch Australian Government Bureau of Meteorology Weather Data.” The Journal of Open Source Software, 2 (17), 411. https://doi.org/10.21105/joss.00411

Sparks, A.H., Carroll, J., Goldie, J., Marchiori, D., Melloy, P., Padgham, M., Parsonage, H. \& Pembleton, K. (2020) bomrang: Australian Government Bureau of Meteorology (BOM) Data Client. R package version 0.7.1. Available from; https:// CRAN.R-project.org/package=bomrang (accessed 1 November 2021) https://doi.org/10.21105/joss.00411

Stamatakis, A. (2014) RAxML Version 8: A tool for phylogenetic analysis and post-analysis of large phylogenies. Bioinformatics, 30, 1312-1313. https://doi.org/10.1093/bioinformatics/btu033

Swofford, D.L. (2003) PAUP. Phylogenetic Analysis Using Parsimony (and other methods). Version 4. Sinauer Associates, Sunderland, Massachusetts. [program]

Symula, R., Keogh, J.S. \& Cannatella, D.C. (2008) Ancient phylogeographic divergence in southeastern Australia among populations of the widespread common froglet, Crinia signifera. Molecular Phylogenetics and Evolution, 47, 569-580.

Toews, D.P.L. \& Brelsford, A. (2012) The biogeography of mitochondrial and nuclear discordance in animals. Molecular Ecology, 21, 3907-3930.

Trifinopoulos, J., Nguyen, L.T., von Haeseler A. \& Minh, B.Q. (2016) W-IQ-TREE: a fast online phylogenetic tool for maximum likelihood analysis. Nucleic Acids Research, 44 (W1), W232-W235. https://doi.org/10.1093/nar/gkw256

Tyler, M.J. \& Davies, M. (1978) Species-groups within the Australopapuan hylid frog genus Litoria Tschudi. Australian Journal of Zoology, Supplementary Series, No. 63, 1-47. https://doi.org/10.1016/j.ympev.2008.01.011

Tyler, M.J. \& Davies, M. (1983) A new species of Litoria (Anura: Hylidae) from Irian Jaya, New Guinea. Copeia, 1983, 803-808. https://doi.org/10.2307/1444349

Vences, M., Thomas, M., Bonett, R.M. \& Vieites, D.R. (2005) Deciphering amphibian diversity through DNA barcoding: chances and challenges. Philosophical Transactions of the Royal Society London, Series B, 360, 1859-1868. https://doi.org/10.1098/rstb.2005.1717

Watters, J.L., Cummings, S.T., Flanagan, R.L. \& Siler, C.D. (2016) Review of morphometric measurements used in anuran species descriptions and recommendations for a standardized approach. Zootaxa, 4072 (4), 477-495.

https://doi.org/10.11646/zootaxa.4072.4.6

\section{SUPPLEMENTARY DATA}

Supplementary Tables S1, S2 and the ND4 alignment are available online at: https://figshare.com/collections/_ 15658028

SUPPLEMENTARY FIGURE S1. A-B) Biplots of morphology summary. PC1 and PC2 versus latitude by sex; C-D) PCA variable loadings.

SUPPLEMENTARY FIGURE S2. A-B) Biplots of two call traits versus latitude. 


\section{Appendix}

\section{Provenance of the holotype of Hyla dentata Keferstein 1868.}

The introduction to Keferstein (1868) indicates that the Australian frogs he examined were obtained by from two sources: Gerard Krefft, of the Australian Museum, Sydney, and Dr. R. Schuette (also spelt Schütte in some records - we retain the spelling Schuette consistently here). Schuette and Krefft, fellow Germans, were friends during their time in Sydney. Schuette was the witness at Krefft's wedding in February 1869 (Nancarrow 2009), and Krefft reportedly arranged the shipping of Schuette's specimens home to Germany (Böhme 2014), although the relationship had soured by 1880 when Schuette was a major creditor in Gerard Krefft's insolvency (Anonymous 1880). The localities listed by Keferstein (1868) are mostly from New South Wales: Clarence River, Sydney, Randwick (a Sydney suburb), and North Shore (presumably of Sydney; this term is still used today), though some are from Pine Mountain (Queensland) and King George's Sound (Western Australia). The majority are from Sydney and Clarence River. There are a few specimens (the Hyla dentata type is one of these) that have just New South Wales for the collection location.

Given that two species in the Litoria dentata complex occur in New South Wales, that the colony of New South Wales included Queensland (where the third species occurs) until 1859, and that the holotype of Hyla dentata is likely a female, lacking the morphological features that distinguish the three species, it is important to consider the geographic provenance of the holotype in order to restrict the name dentata to one of the species.

Keferstein (1868) did not record which specimens were obtained from Krefft and which from Schuette. However, published lists of herpetological type specimens in the ZFMK (Bonn) collection, which received the then-inactive Göttingen collection in 1977, including the hand-written catalogues (Böhme \& Bischoff 1984; Böhme 2014), records the type of Hyla dentata as being from Schuette and received in 1867, though still with the imprecise locality of New South Wales.

Dr R. Schuette is Dr Bernard Rudolf Schuette, who was born in Hildesheim, Germany, on 17 September 1835. He initially trained as a pharmacist, first coming to Australia for a six year period in that field before returning to Germany in 1862 to study medicine at Göttingen (Ehlers 1901). There are few records of his activities during this first period in Australia. Presumably, at the age of just 21 on his first arrival in Australia in 1857, he would have been working as an assistant pharmacist rather than running a significant business of his own, which may explain the lack of records of any business in his name or movements in the press and other contemporary records. However, he appears to have arrived in Adelaide from Hamburg aboard the barque Victoria, arriving on 7 February 1857 (Anonymous 1857). In January 1861, a Rudolph Schuette donated a monitor lizard (presumably Varanus varius, the locally common monitor species) collected at Manly to the Australian Museum (Anonymous 1861) suggesting he had moved to Sydney by that time. His contact with Krefft, who was then Assistant Curator at the Australian Museum under Simon Rood Pittard (Nancarrow 2009) is likely to have dated from at least then. A Mr Schuette then departed Sydney for London aboard the Liberator on 19 April 1862 (Anonymous 1862), corresponding with the year Rudolf Schuette was reported to have returned to Europe by Ehlers (1901).

After completing his medical degree in 1865 and being made a Licentiate of the Apothecaries Associate (London) in 1866 (Anonymous 1868), Schuette returned to Australia as a surgeon. Although the date of his arrival in Australia is not known, he was first registered as a medical practitioner in New South Wales, receiving his certification (\#621) on 7 January 1867 (Anonymous 1868), although this was only formally ratified on 2 April 1867 (Mitchell et al. 1867) (certificates \#612-617 were all dated 8 January, but \#618-620 and 622 were all dated 2 April, suggesting a delay in acceptance of Schuette's credentials). A few days later, Schuette travelled from Sydney to the Clarence River on the Susannah Cuthbert, arriving there on 14 April (Anonymous 1867a), and advertised his practice in Grafton two days later (Anonymous 1867b). The close approximation of these dates suggest that he had only recently arrived in Australia to practice his profession by early January, and presumably would have spent much of the first few months in Sydney organising his affairs, although we cannot exclude the possibility that he made some local Sydney frog collections during that time. He remained in the Grafton area for several months, last advertising his business in the local press on 20 August (Anonymous 1867c), and returned to Sydney aboard the Agnes Irving on 25 September (Anonymous 1867d) becoming the house physician to the Sydney Infirmary (Anonymous $1867 \mathrm{e}$ ). His date of appointment to that position cannot be ascertained, although the position was last advertised on 27 September, with a closing date of 29 September (Anonymous 1867f). Assuming that shipping of the specimens from 
Schuette in New South Wales to Keferstein in Göttingen would have taken several months (Schuette's first voyage to Australia took 100 days from Hamburg to Adelaide; Anonymous 1857), it seems most likely that he collected the specimens during his time on the Clarence River, and shipped them to Göttingen either from the Clarence via Sydney, or immediately on returning to Sydney, in order for them to have been received by Keferstein in Göttingen before the end of 1867. Other Schuette frogs with the locality Clarence River (the seven syntypes of Pseudophryne coriacea) also have an 1867 date (Böhme 2014), indicating that the 1867 shipment must have occurred after his arrival in Grafton.

After two years working at the Sydney Infirmary, Schuette commenced in private practice in Castlereagh Street, Sydney in February 1870 (Anonymous 1870a), and the same month married Johanna Sophia Bockstoever of Hanover at St James Church in Sydney (Anonymous 1870b). Their first son, Rudolf William (who would later also become a medical practitioner in Sydney), was born 15 December 1870 (Anonymous 1870c). In February 1873, Schuette moved practice to College Street, Sydney (Anonymous 1873a). Their second son (Otto) was born $11 \mathrm{Au}-$ gust 1873 (Anonymous 1873b), and a third son, Hermann, was born on 12 November 1876 (Anonymous 1876). A daughter, Maria Caroline, was born on 8 October 1878 (Anonymous 1878). Schuette left Sydney with his family to return to Germany on 21 June 1884, aboard R.M.S. Orient, and died in Leipzig on 18 July 1886, aged 50, following an operation to attempt to resolve an unspecified medical condition (Anonymous 1884, 1886a,b; Ehlers (1901) gives his death date as 16 July).

During his time in Sydney from late 1867 to June 1884, Schuette seems to have been devoted to his profession. We can find only two occasions when he left Sydney, the first in June 1873, when he travelled to Fiji aboard the schooner Dancing Wave (Anonymous 1873c), and the second in early 1883, when he travelled to New Zealand for a few weeks, leaving by the Wairarapa on 15 February (Anonymous 1883).

Although Böhme and Bischoff (1984) record that Schuette was Keferstein's brother-in-law, this seems unlikely. Schuette's wife Johanna Sophia was the daughter of Wilhelm and Sophie Bockshoever of Calle, Hanover (Anonymous $1872 \mathrm{a}, \mathrm{b}$ ) rather than a Keferstein. Further, Schuette married Johanna one month after Keferstein had died, aged 37, so his contact with Keferstein had occurred before Schuette's marriage. It is possible that there was an earlier wife for Schuette, prior to his arrival in Australia, but there are no records of this. Conversely, a death notice for Schuette's sister Maria Schuette of Nordhausen, Prussia, reports that she was his only sister (Anonymous 1873d). We have been unable to trace Keferstein's family tree, but it seems unlikely that Keferstein's wife (if he married) was a Schuette of Rudolf's immediate family. Hence, the relationship between Keferstein and Schuette was likely to be more distant.

Keferstein, two years older than Schuette, is likely to have first had professional contact with Schuette when the latter was in Göttingen undertaking his medical degree, although their familial relationship may have resulted in contact prior to that. Keferstein had earlier completed his medical degree there in 1856 (the year Schuette departed Hamburg for his first Australian sojourn), so they were not medical students together. However, Keferstein was Curator at the museum in Göttingen while Schuette was undertaking his medical degree (and had earlier taught animal anatomy (zootomy) at the University). The Schuette anuran type material listed by Böhme (2014) has two sets of dates: 1864 and 1867. Those from 1864 (the majority) are likely to have been obtained from Schuette's first Australian period, and transferred to Keferstein directly at Göttingen (this also fits with the lack of any Clarence River specimens from Schuette in an earlier paper on Australian frogs by Keferstein (1867), published in July of that year, for which the Schuette-sourced types were only associated with the 1864 date; Böhme 2014). However, it is unlikely that Schuette would have retained the second batch of specimens through his four year period in Göttingen, only to later send them to Keferstein after his return to Australia in 1867. Hence, we assume that the 1867 specimens were collected during his second period in Australia. As Schuette had already made a collection of the local Sydney frogs during his first Australian visit, it is less likely that he made a second collection from there in 1867, and more likely the 1867 frogs came from the new collecting locality of Grafton.

Schuette's other claim to biological fame is his involvement in sending the type specimen of the Ghost Bat, Macroderma gigas, to Göttingen (Dobson 1880). The specimen was reported to have been collected by a Mr Wilson from Mount Margaret, Wilson's River, Central Queensland. Although no date is associated with this specimen, it is likely to have been sent in 1879-80, and collected shortly before (Nelson 1988), as this specimen was also the basis of Krefft's report of the species to a meeting of the Zoological Society of London in May 1879, suggesting that Krefft had seen the specimen in Sydney a few months before then. Hence, it is unlikely that this record implies any visit by Schuette to Queensland before 1867. 
Consequently, the most likely source for the holotype of Hyla dentata, collected by Schuette and received by Keferstein in 1867 is the nascent Grafton settlement on the Clarence River, NSW.

Anonymous (1857) Shipping Intelligence. South Australian Register, 9 February 1857, 2.

Anonymous (1861) List of donations to the Australian Museum during January, 1861. Sydney Morning Herald, 14 February $1861,4$.

Anonymous (1862) Shipping Gazette. Sydney Mail, 26 April 1867, 1.

Anonymous (1867a) Shipping Intelligence. Clarence and Richmond Examiner and New England Advertiser, 16 April $1867,2$.

Anonymous (1867b) Medical. Clarence and Richmond Examiner and New England Advertiser, 16 April 1867, 2.

Anonymous (1867c) Rudolf Schutte, M.D., L.A.H., London. Clarence and Richmond Examiner and New England Advertiser, 20 August 1867, 1.

Anonymous (1867d) Shipping. Empire, 27 September 1867, 4.

Anonymous (1867e) Coroner's Inquest. Sydney Morning Herald, 29 November 1867, 4.

Anonymous (1867f) Medical Men. Sydney Morning Herald, 27 September 1867, 8.

Anonymous (1868) Register of Medical Practitioners for 1868. New South Wales Government Gazette, 51, $592-598$ (3 March 1868).

Anonymous (1870a) Business Cards. Sydney Morning Herald, 14 February 1870, 1.

Anonymous (1870b) Marriages. Sydney Morning Herald, 16 February 1870, 1.

Anonymous (1870c) Births. Sydney Morning Herald, 17 December 1870, 1.

Anonymous (1872a) Deaths. Sydney Morning Herald, 11 September 1872, 1.

Anonymous (1872b) Deaths. Sydney Morning Herald, 24 September 1872, 1.

Anonymous (1873a) Public Notices. Sydney Morning Herald, 4 February 1873, 2.

Anonymous (1873b) Births. Sydney Morning Herald, 16 August 1873, 1

Anonymous (1873c) Shipping. Sydney Morning Herald, 9 June 1873, 4.

Anonymous (1873d) Deaths. Sydney Morning Herald, 19 November 1873, 1.

Anonymous (1876) Births. Sydney Morning Herald, 25 November 1876, 1.

Anonymous (1878) Births. Sydney Morning Herald, 22 October 1878, 1.

Anonymous (1880) Insolvency Court. Sydney Morning Herald, 29 July 1880, 3.

Anonymous (1883) Clearances. Sydney Mail and New South Wales Advertiser, 24 February 1883, 374.

Anonymous (1884) Projected departures by sea. Daily Telegraph, 21 June 1884, 1.

Anonymous (1886a) Obituary. Evening News, 22 July 1886, 5.

Anonymous (1886b) The late Dr Schuette. Clarence and Richmond Examiner and New England Advertiser, 31 July $1886,3$.

Böhme, W. (2014) Herpetology in Bonn. Mertensiella, 21, 1-256.

Böhme, W. \& Bischoff, W. (1984) Amphibien und Reptilien. In: Rheinwald, G. (Hrsg.): Die Wirbeltiersammlungen des Museums Alexander Koenig. Bonner Zoologische Monographien, 19, 151-213.

Dobson, G.E. (1880) On some new or rare species of Chiroptera in the collection of the Göttingen Museum. Proceedings of the Zoological Society of London, 1880, 461-465 + pl. XLVI.

Ehlers, E. (1901) Gootinger Zoologen. In: Festschrift zur Feier des hundertfünfzigjährigen Bestehens der Köninglichen Gesellschaft der Wissenschaft zu Göttingen. Weidmann'sche Buchhandlung, Berlin. pp. 391-494.

Keferstein, W. (1867) Ueber einige neue oder seltene Batrachier aus Australien und dem tropischen Amerika. Nachrichten von der Konigl. Gesellschaft der Wissenschaften und der G. A. Universität zu Göttingen, (18), 341-361.

Keferstein, W. (1868) Uber die Batrachier Australiens. Archiv für Naturgeschichte, 34, 253-90.

Mitchell, J., Nathan, C. \& M'Kay, C. (1867) Legally qualified medical practitioners. New South Wales Government Gazette, (57), 890 (5 April 1867).

Nancarrow, J. (2009) Gerard Krefft: a singular man. Proceedings of the Royal Society of Victoria, 121, $146-154$.

Nelson, J. (1988) Where is the type locality of Macroderma gigas? Macroderma, (4), 70-72. 